Prepared for the U.S. Department of Energy

under Contract DE-AC05-76RL01830

\title{
Impact of E4 Training and Field Auditing of GSA Heartland Region Facilities
}

N Fernandez

K Gowri

RM Underhill

JK Goddard

April 2012

\section{Pacific Northwest}

NATIONAL LABORATORY

Proudly Operated by Battelle Since 1965 


\title{
DISCLAIMER
}

This documentation was prepared as an account of work sponsored by an agency of the United States Government. Neither the United States Government nor any agency thereof, nor Battelle Memorial Institute, nor any of their employees, makes any warranty, express or implied, or assumes any legal liability or responsibility for the accuracy, completeness, or usefulness of any information, apparatus, product, or process disclosed, or represents that its use would not infringe privately owned rights. Reference herein to any specific commercial product, process, or service by trade name, trademark, manufacturer, or otherwise does not necessarily constitute or imply its endorsement, recommendation, or favoring by the United States Government or any agency thereof, or Battelle Memorial Institute. The views and opinions of authors expressed herein do not necessarily state or reflect those of the United States Government or any agency thereof.

\author{
PACIFIC NORTHWEST NATIONAL LABORATORY \\ operated by \\ BATTELLE \\ for the \\ UNITED STATES DEPARTMENT OF ENERGY \\ under Contract DE-AC05-76RL01830 \\ Printed in the United States of America \\ Available to DOE and DOE contractors from the \\ Office of Scientific and Technical Information, \\ P.O. Box 62, Oak Ridge, TN 37831-0062; \\ ph: (865) 576-8401, fax: (865) 576-5728 \\ email: reports@adonis.osti.gov

\begin{abstract}
Available to the public from the National Technical Information Service,
U.S. Department of Commerce, 5285 Port Royal Rd., Springfield, VA 22161

ph: (800) 553-6847, fax: (703) 605-6900

email: orders@ntis.fedworld.gov
\end{abstract} \\ online ordering: http://www.ntis.gov/ordering.htm
}

This document was printed on recycled paper.

$(8 / 00)$ 
PNNL-21444

\title{
Impact of E4 Training and Field Auditing of GSA Heartland Region Facilities
}

\author{
N Fernandez \\ K Gowri \\ RM Underhill \\ JK Goddard
}

April 2012

Prepared for

Federal Energy Management Program U.S. Department of Energy

under Contract DE-AC05-76RL01830

Pacific Northwest National Laboratory

Richland, Washington 99352 



\section{Executive Summary}

Since 2007, PNNL conducted eight Energy Efficiency Expert Evaluation (E4) ${ }^{1}$ training workshops and field audits of eight General Services Administration (GSA)-owned Federal buildings in Region 6 (Iowa, Kansas, Missouri and Nebraska). The training was attended by GSA regional property managers, facility managers and operations and maintenance $(\mathrm{O} \& \mathrm{M})$ contractors, totaling about 110 participants. The gross floor area of all the facilities covered by E4 field audit is approximately 4.7 million square feet. The E4 training focused on identifying low-cost/no-cost opportunities for improving the energy efficiency of the facility. A facility walkthrough visual inspection and an in-depth review of the control system were conducted as part of the training. A list of recommendations was developed for each site based on the observations made during field training, building automation system (BAS) reviews, and based on an analysis of utility billing data. The following six low-cost/no-cost recommendations were found to be most common for all facilities:

1. De-lamping brightly lit corridor and office area light fixtures

2. Lighting schedule revisions, new sensors/controls and integration with BAS

3. Heating, ventilation and air conditioning (HVAC) equipment and air-handler operation schedule adjustments

4. Chilled water supply temperature and differential pressure reset

5. Static pressure set point reset for unoccupied hours

6. Economizer operational improvements (failed sensors or control strategy).

All of the above recommendations could be implemented as part of routine operation and maintenance of the facility without requiring additional investment. A few recommendations (such as control system upgrades or HVAC equipment upgrade or replacement) requiring additional investment were also identified and recommended as potential capital projects.

To assess the impact of E4 training and field audit, the Federal Energy Management Program (FEMP) undertook a follow-up study on the implementation of E4 recommendations and an analysis of energy savings. The building property manager and O\&M contractor of each facility were interviewed to obtain feedback and implementation status of the E4 recommendations. Overall, there were more than 160 recommendations documented in the E4 reports; about $50 \%$ of these recommendations were fully implemented and the remaining 50\% either partially implemented or not implemented. In four buildings, the E4 recommendations were aligned with American Recovery and Reinvestment Act of 2009 (ARRA) projects replacing HVAC equipment or upgrading the building control system. The E4 recommendations were not followed-up in two buildings because of uncertainty of the long-term use of the facility or personnel changes.

As part of the impact assessment, the utility bills for 12 months prior to the initial E4 visits and for FY11 were compared. The overall energy savings for the eight facilities is $6.4 \%$ with a range of $-0.8 \%$ to $17.3 \%$ depending on the implementation of E4 recommendations and the impact of ARRA projects. When compared to FY10, FY11 savings are $6.3 \%$ without adjusting for weather and $6.1 \%$ after adjusting for weather. A similar improvement in Energy Star rating has been observed at six of the eight facilities, typically by 2 to 3 percentage points annually.

\footnotetext{
${ }^{1}$ The primary objectives of the E4 evaluations are to identify and realize low-cost/no-cost energy savings opportunities at Federal facilities. E4 teams accomplish these objectives by working with site staff to evaluate equipment/systems operations and maintenance, identify energy saving opportunities and develop appropriate action plans, outlining the steps and milestones necessary to realize energy savings.
} 
Based on the review of E4 recommendations, impact assessment and utility bill analysis, the following conclusions can be made:

1. E4 audits have been very effective in educating building staff and contractors in evaluations methods to identify and prioritize low-cost/no-cost measures. Even when half of the recommended measures are implemented, it is possible to achieve about $6 \%$ annual energy savings without significant additional investments for capital projects. The E4 operator training provided, along with continued regional interest and oversight, will help ensure these improvements and their resulting savings persist.

2. Field auditing and identifying low-cost recommendations to the building managers do not always result in implementation of the measures. Active one-on-one engagement of the building managers and facility staff is critical to achieving implementation, particularly with measures that alter building schedules and controls settings. Strong field office management support is the first requirement to implementation of these types of changes. Building managers, staff, and O\&M contractors are often resistant to these changes for fear that the modifications will result in tenant complaints. Therefore, these modifications often require a monitored performance period that validates the changes do not negatively impact tenant comfort.

3. O\&M contractors are often limited in their 'authority' to modify control settings. In addition, the E4 audits have also found that O\&M contractors may be limited by their ability to add or modify control systems programming for retuning measures and require the assistance of control systems contractors. Current work undertaken by GSA for targeted $\mathrm{E} 4^{2}$ training, which includes on-site support and system monitoring, has demonstrated that the O\&M contractors gain not only knowledge of how to implement the controls changes, but they also gain confidence and understanding of how to monitor the systems and/or modify settings if needed. Greater knowledge and confidence in working with the building controls systems to implement and modify controls measures is seen by GSA as a potential long-term solution that will help this approach of systematically identifying practical, low-cost measures - often referred to as "retuning" - become a part of the regular maintenance rather than a capital project.

\footnotetext{
${ }^{2}$ GSA Region 6 has funded PNNL in FY12 to conduct targeted E4 assessments to address building retuning with training, monitoring and support for four facilities in the region.
} 


\section{Acknowledgements}

The authors wish to thank Mr. Chris Cockrill, Ms. Linda Baschnagel and Ms. Susan Hall of the GSA Heartland Region for their help in organizing the field visits and workshops.

The authors would also like to thank Dr. Srinivas Katipamula, Mr. John Hail, Mr. Bill Sandusky and Mr. Dave Hunt of Pacific Northwest National Laboratory for their assistance in developing the training materials and valuable input throughout the course of this project. 


\section{Contents}

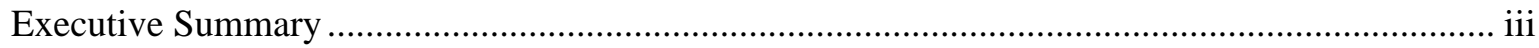

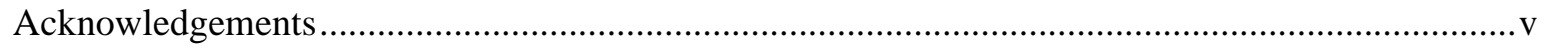

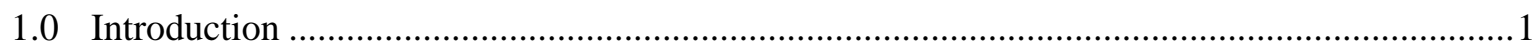

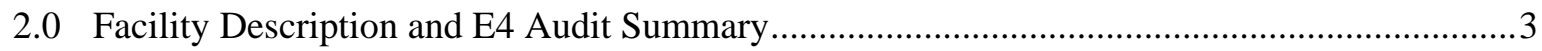

2.1 Neal Smith Federal Building .....................................................................................

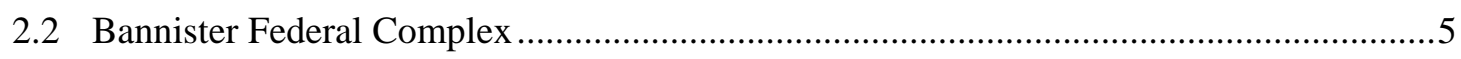

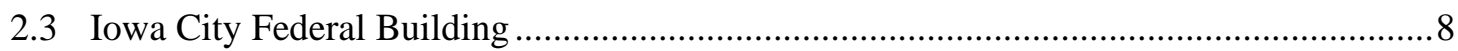

2.4 Robert A Young (RAY) Federal Building ……...........................................................11

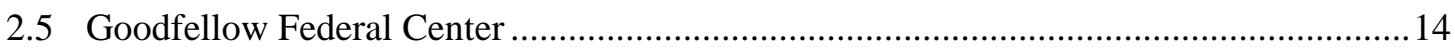

2.6 Frank Carlson Federal Building and Courthouse .......................................................16

2.7 Charles Evans Whittaker U.S. Courthouse ....................................................................18

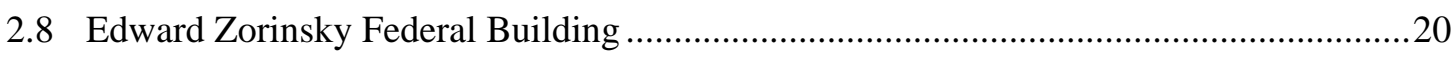

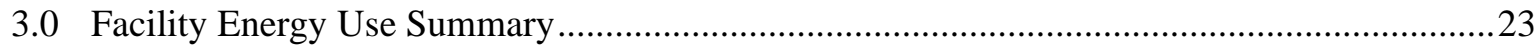

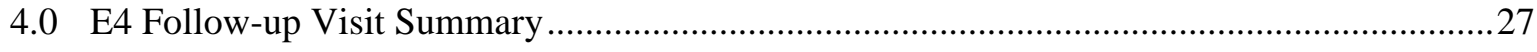

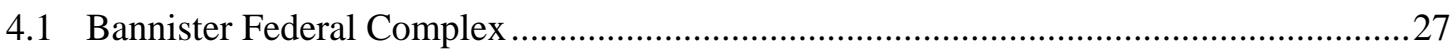

4.2 Frank Carlson Federal Building and Courthouse ........................................................28

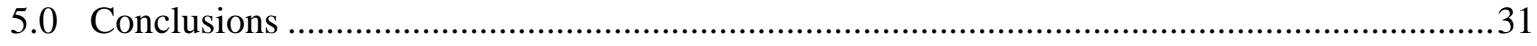

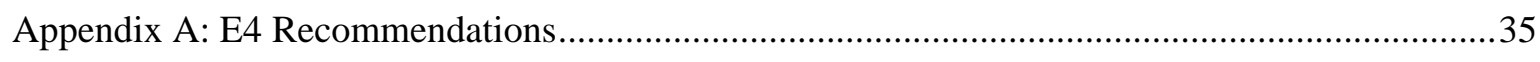

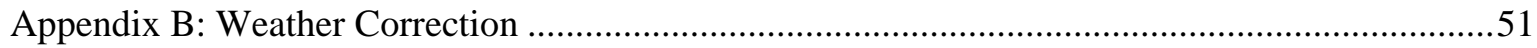




\section{Figures}

Figure 1: Implementation Status of E4 Recommendations in Neal Smith Federal Building.............4

Figure 2: Annual and Monthly Weather-Corrected EUIs at Neal Smith Federal Building ...............5

Figure 3: Weather-Corrected Energy Savings by Fuel Type at Neal Smith Federal Building ...........5

Figure 4: Implementation Status of E4 Recommended Measures at the Bannister Federal Complex

Figure 5: Annual and Monthly Weather-Corrected EUIs at the Bannister Federal Complex ............7

Figure 6: Weather-Corrected Energy Savings by Fuel Type at the Bannister Federal Complex .......7

Figure 7: Implementation Status of E4 Recommended Measures at Iowa City Federal Building .....9

Figure 8: Annual and Monthly Weather-Corrected EUIs at Iowa City Federal Building ................10

Figure 9: Weather-Corrected Energy Savings by Fuel Type at Iowa City Federal Building ...........10

Figure 10: Implementation Status of E4 Recommendations at RAY Federal Building ..................12

Figure 11: Annual and Monthly Weather-Corrected EUIs at RAY Federal Building.....................13

Figure 12: Weather-Corrected Energy Savings by Fuel Type at RAY Federal Building .................13

Figure 13: Implementation Status of E4 Recommendations at Goodfellow Federal Center

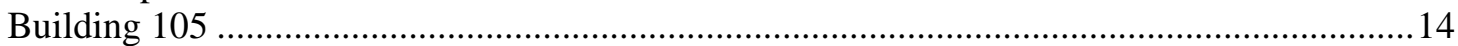

Figure 14: Annual and Monthly Weather-Corrected EUIs at Goodfellow Federal Center...............15

Figure 15: Weather-Corrected Energy Savings by Fuel Type at Goodfellow Federal Center.........15

Figure 16: Implementation Status of E4 Recommendations Implemented at Carlson Federal

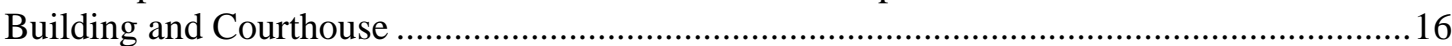

Figure 17: Annual and Monthly Weather-Corrected EUIs at Carlson Federal Building and

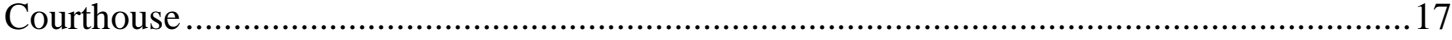

Figure 18: Weather-Corrected Energy Savings by Fuel Type at the Carlson Federal Building and Courthouse

Figure 19: Implementation Status of E4 Recommendations at Whittaker Courthouse ...................19

Figure 20: Annual and Monthly Weather-Corrected EUIs at Whittaker Courthouse......................20

Figure 21: Weather-Corrected Energy Savings by Fuel Type at Whittaker Courthouse..................20

Figure 22: Implementation Status of E4 Recommendations at Zorinsky Federal Building ............21

Figure 23: Annual and Monthly Weather-Corrected EUIs at Zorinsky Federal Building................22

Figure 24: Weather-Corrected Energy Savings by Fuel Type at Zorinsky Federal Building ...........22

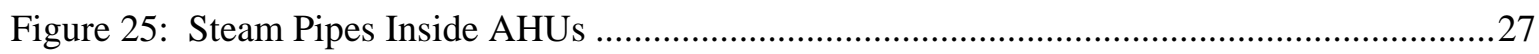

Figure 26: Heating Degree Days for Des Moines, IA................................................................51

Figure 27: Cooling Degree Days for Des Moines, IA …............................................................52

Figure 28: Correlations between Electricity Consumption and Weather for Bannister Complex

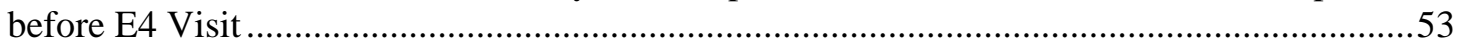




\section{Tables}

Table 1: Annual Energy Use Intensities Across the E4 Building Portfolio .....................................23

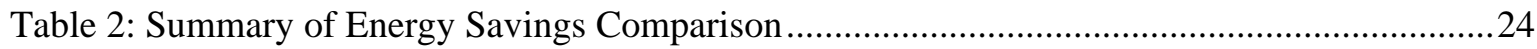

Table 3: EnergyStar Report Summary for all E4 Sub-metered Buildings ......................................25

Table 4: Targeted-E4 Recommendations and Expected Savings .................................................29

Table 5: Electricity Bill Summary (post- Targeted-E4 Visits) …..................................................29

Table 6: Measures Fully or Partly Implemented - Neal Smith Federal Building .............................35

Table 7: Measures Not Implemented - Neal Smith Federal Building ...........................................35

Table 8: Measures Fully or Partly Implemented - Bannister Federal Complex ..............................36

Table 9: Measures Not Implemented - Bannister Federal Complex ..............................................37

Table 10: Measures Fully or Partly Implemented - Iowa City Federal Building ............................38

Table 11: Measures Not Implemented - Iowa City Federal Building ..........................................39

Table 12: Measures Fully or Partly Implemented - Robert A Young Federal Building .................40

Table 13: Measures Not Implemented - Robert A Young Federal Building..................................41

Table 14: Measures Fully or Partly Implemented - Goodfellow Federal Center ...........................42

Table 15: Measures Not Implemented - Goodfellow Federal Center ...........................................43

Table 16: Measures Fully or Partly Implemented - Frank Carlson Federal Building and

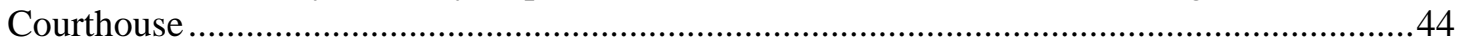

Table 17: Measures Not Implemented - Frank Carlson Federal Building and Courthouse ............45

Table 18: Measures Fully or Partly Implemented - Charles Evans Whittaker U.S. Courthouse ....46

Table 19: Measures Not Implemented - Charles Evans Whittaker U.S. Courthouse.......................47

Table 20: Measures Fully or Partly Implemented - Edward Zorinsky Federal Building ................48

Table 21: Measures Not Implemented - Edward Zorinsky Federal Building .................................48 


\subsection{Introduction}

The Federal Energy Management Program (FEMP) Energy Efficiency Expert Evaluation (E4) program assists Federal sites in the identification and realization of energy savings and efficiency improvements, primarily through low-cost/no-cost actions, and operations and maintenance (O\&M) improvements. In FY06, FEMP found an average potential savings of $10 \%$ was identified for natural gas systems, with simple paybacks well under 2 years. During FY05, PNNL developed a building retuning and training program for operational improvements in Washington State ${ }^{1}$. A combination of E4 evaluations and retuning training was proposed to the General Services Administration (GSA) Region 6 in FY07, and the first such training was held in Neal Smith Federal Building in Des Moines, Iowa. Based on feedback from the field staff, GSA requested similar training to be conducted in other facilities with a goal to meet the Executive Order 13423 and EISA 2007, to reduce energy intensity by 3\% each year, leading to 30\% savings by the end of FY15 compared to an FY03 baseline.

Since 2007, PNNL has conducted eight E4 training workshops and performed field evaluations at GSAowned Federal buildings and courthouses in the Heartland Region (GSA Region 6). Specific sites and the dates of the workshops are listed below:

1. Neal Smith Federal Building

2. Bannister Federal Complex

3. Iowa City Federal Building

4. Robert A. Young Federal Building

5. Goodfellow Federal Center

6. Frank Carlson Federal Building and Courthouse

7. Charles Evans Whittaker U.S. Courthouse

8. Edward Zorinsky Federal Building

Des Moines, IA
Kansas City, MO
Iowa City, IA
Saint Louis, MO
Saint Louis, MO
Topeka, KS
Kansas City, MO
Omaha, NE

November 1, 2007

April 27-29, 2009

December 1-2, 2009

February 3-4, 2010

March 3-4, 2010

May 3-4, 2010

June 22-23, 2010

December 7-8, 2010.

These workshops and site visits had two components: a building walkthrough evaluation and a training session for facility managers and O\&M staff. The building walkthrough evaluation was performed by Pacific Northwest National Laboratory (PNNL) staff, and involved interviews with building personnel and identification of low-cost/no-cost improvements that, if implemented on a continual basis, could result in savings of between 3 and 5\% of site energy usage annually depending on the potential to identify and implement new retuning measures. Also identified were capital intensive projects that could be implemented as time and budgets become available to achieve greater, cost-effective energy savings. The training sessions involved both a class room and a hands-on session to present ways to identify energy savings opportunities, and patterns of faults and wasted energy within the building automation system (BAS).

To assess the impact of the E4 training, FEMP requested PNNL to undertake this follow-up study to review the implementation status of the $\mathrm{E} 4$ recommendations and document energy savings achieved. The scope of work undertaken for this report includes:

1. Interviews with facility managers and O\&M staff to find out which measures were implemented and not implemented, and identify any challenges and/or barriers to implementation

2. Estimate energy savings since E4 workshops, using utility bills for all eight sites

\footnotetext{
${ }^{1}$ Brambley, MR and S Katipamula, "Retuning Commercial Buildings: A Low-Cost Way to Improve Energy Performance”, ASHRAE Journal 51(10): 12-23 (October 2009)
} 
3. Perform follow-up site visits to two facilities to validate and implement any outstanding energy efficiency measures to the building automation system.

This report provides a description of each facility, status of E4 recommendations and energy savings for all the eight buildings (Section 2), summary of overall energy impact of these facilities at the regional level (Section 3), and findings from follow-up field visits to the Bannister Federal Complex and Frank Carlson Federal Building and Courthouse (Section 4). A consolidated list of E4 recommendations for each facility and weather normalization details are included in the Appendices. 


\subsection{Facility Description and E4 Audit Summary}

This section provides a brief description of each of the eight buildings audited by the E4 team. This description includes building envelope, lighting and HVAC equipment details, and operational schedules. A summary of E4 recommended measures and their implementation status based on interviews is included in Appendix A. A bubble chart has been created for each facility to visually represent the status of implementation, and provide a qualitative assessment of their energy saving potential and implementation cost. In addition, utility bills for each building were analyzed to create a baseline of energy use before E4 visits and compare it the following year's energy use, after adjusting for weather. The scope of energy savings comparison is limited to assessing the impact of implementing E4 recommendations, and varies for each building depending on the time when the E4 audit was performed.

\subsection{Neal Smith Federal Building}

Neal Smith Federal Building is a 10-story office building built in 1967 with a gross floor area of 390,000 sf., located in downtown Des Moines, IA. The building tenants include Internal Revenue Service, Social Security Administration and Veteran's Administration, with a total of about 750 full-time employees, and some offices have regular public access to visitors. The building operating schedule is from 6:00 a.m. to 6:00 p.m., Monday through Friday. The building's central mechanical system consists of eight air handlers, two chillers, three steam boilers and six hot water boilers. Four of the air handlers are hot/cold deck systems that supply conditioned air to 500 variable-air-volume mixing boxes (VAV) located in ceiling plenums throughout the building. Two other air handlers use heating and cooling coils to supply conditioned air to 320 air-induction units along the exterior walls. The central air-handling units are controlled by a Johnson Controls Metasys ${ }^{2}$ Extended Architecture building management system.

Neal Smith Federal Building in Des Moines is the first GSA Region 6 facility where E4 training and field auditing was conducted in November 2007. About 30 local and regional GSA staff attended the class room and field training.

The E4 team identified 22 energy improvement opportunities in this building, 16 of which were categorized as low-cost/no-cost, and the remaining 6 were recommended as capital projects. Figure 1 shows the status of implementation based on follow-up interviews with facility staff. Each item in this bubble chart refers to an E4 recommendation by number, and an itemized list of recommendations is included in Appendix A (Tables 6 and 7). It can be observed that almost all low-cost measures have been implemented, except for chilled water supply temperature reset, which was originally implemented, but later reset due to humidity control issues. All capital project recommendations are being addressed as part of the American Recovery and Reinvestment Act (ARRA) projects, which are nearing completion.

\footnotetext{
${ }^{2}$ Use of specific tradenames and manufacturers is for research purposes only and does not constitute an endorsement of these products or systems.
} 


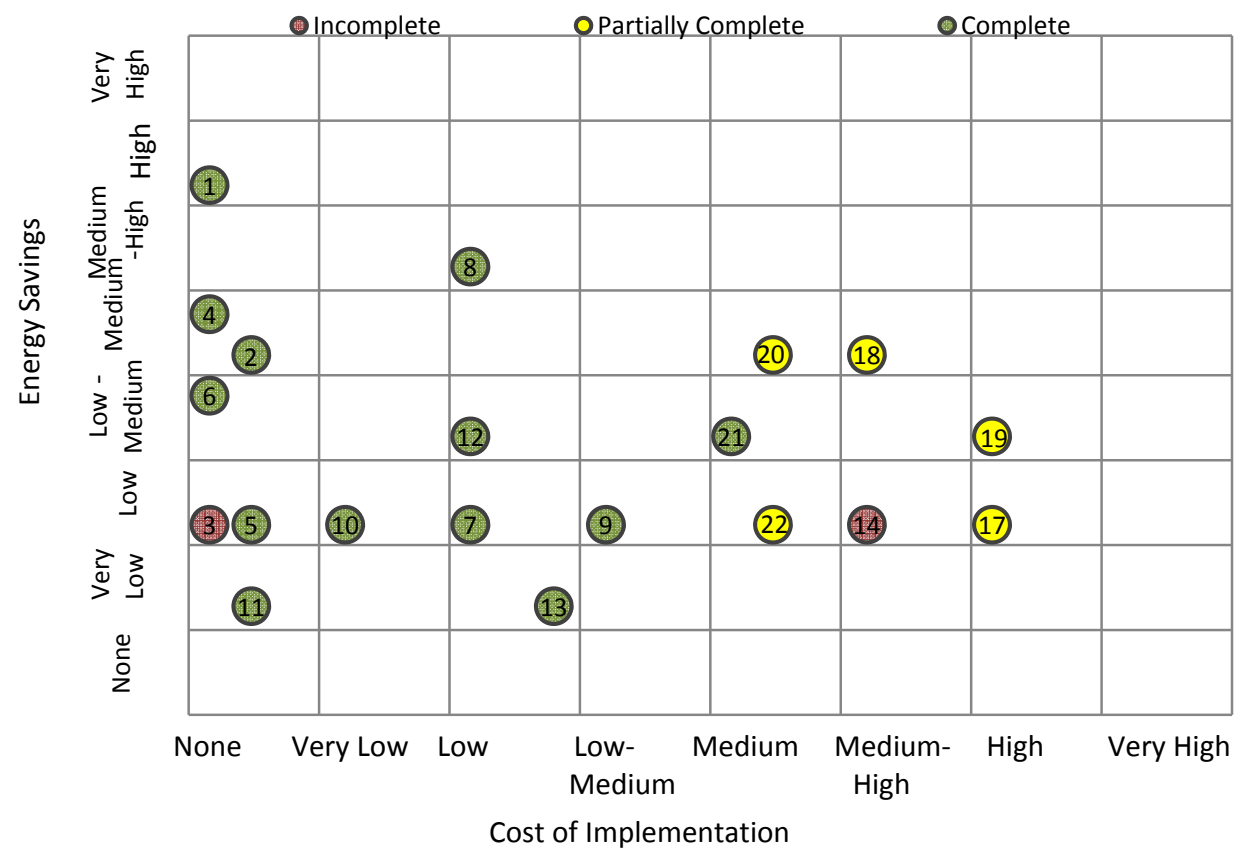

Figure 1: Implementation Status of E4 Recommendations in Neal Smith Federal Building

The E4 team estimated that overall energy saving from implementing low-cost/no-cost measures to be 12\%. Figure 2 and Figure 3 show the weather-corrected energy use intensity (EUI) and energy savings by fuel cost for the past 5 years. There was very little change in total energy consumption at Neal Smith from FY07 to FY09. Then, from FY09 to FY10, the weather-corrected EUI dropped from 77.7 to 67.8 (a $12.8 \%$ reduction). There has been a further $4.4 \%$ drop in weather-corrected EUI from FY10 to FY11. This facility had a chiller replacement done in FY09, independent of E4 recommendations, which helped realize several of the highest energy saving measures. It can be observed that most of the energy savings in FY11 compared to FY07 and FY08 is during the summer months and the shoulder months (April, May, September, and October). Figure 3 shows that there has been continual savings in electricity at the Neal Smith Federal Building since FY09, although gas consumption spiked by over 20\% in FY09, but dropped to its previous level in FY10, and dropped a further 4\% in FY11.

Both the Neal Smith Federal Building field office GSA staff and O\&M contractor have taken the E4 recommendations seriously and followed up on these, resulting in significant reductions in EUI and recently received utility rebates of $\$ 136,000^{3}$. Neal Smith Federal Building E4 results are recognized by the regional GSA staff as setting the benchmark for building retuning.

\footnotetext{
${ }^{3}$ Neal Smith Federal Building Energy Rebates Fund Lighting Upgrades, internet article available at: http://www.gsa.gov/portal/content/285365\#R6NSFBLights - accessed on April 25, 2012
} 


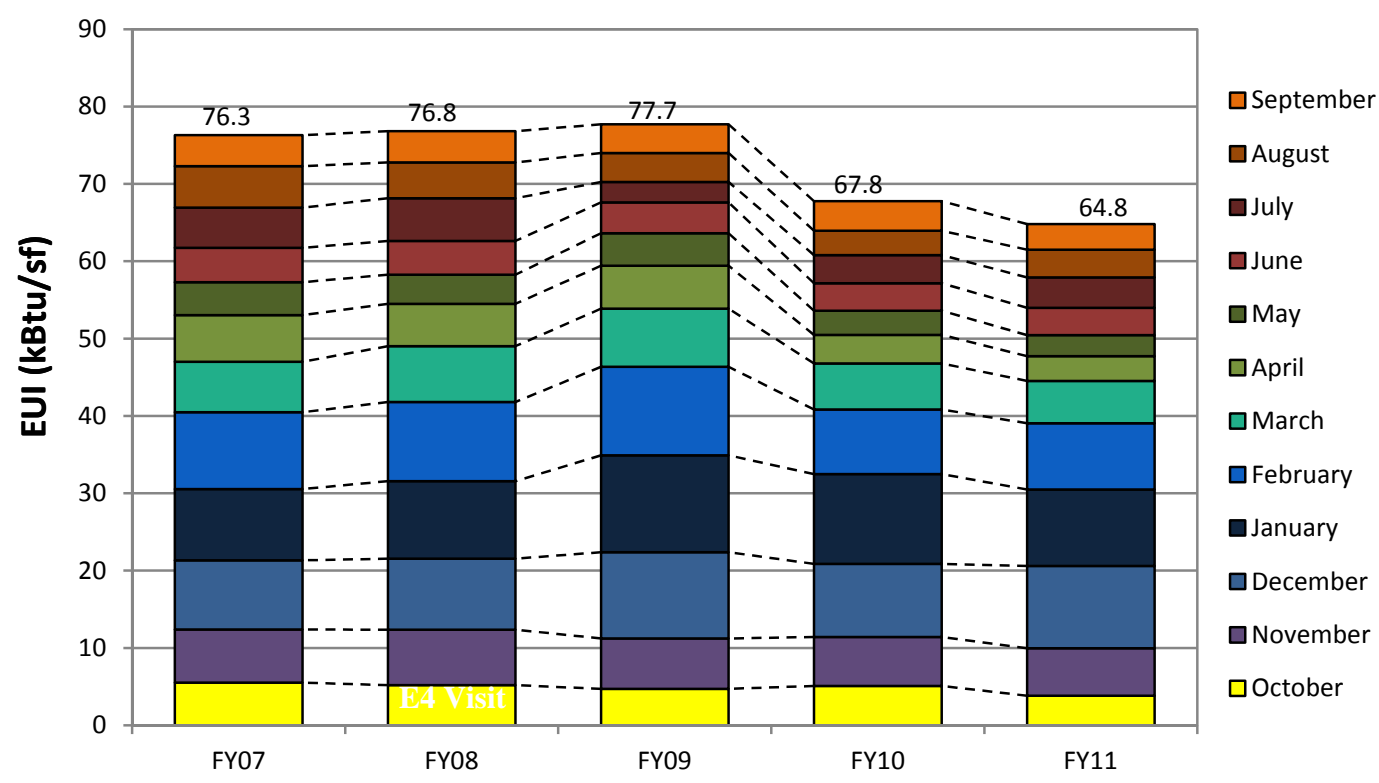

Figure 2: Annual and Monthly Weather-Corrected EUIs at Neal Smith Federal Building

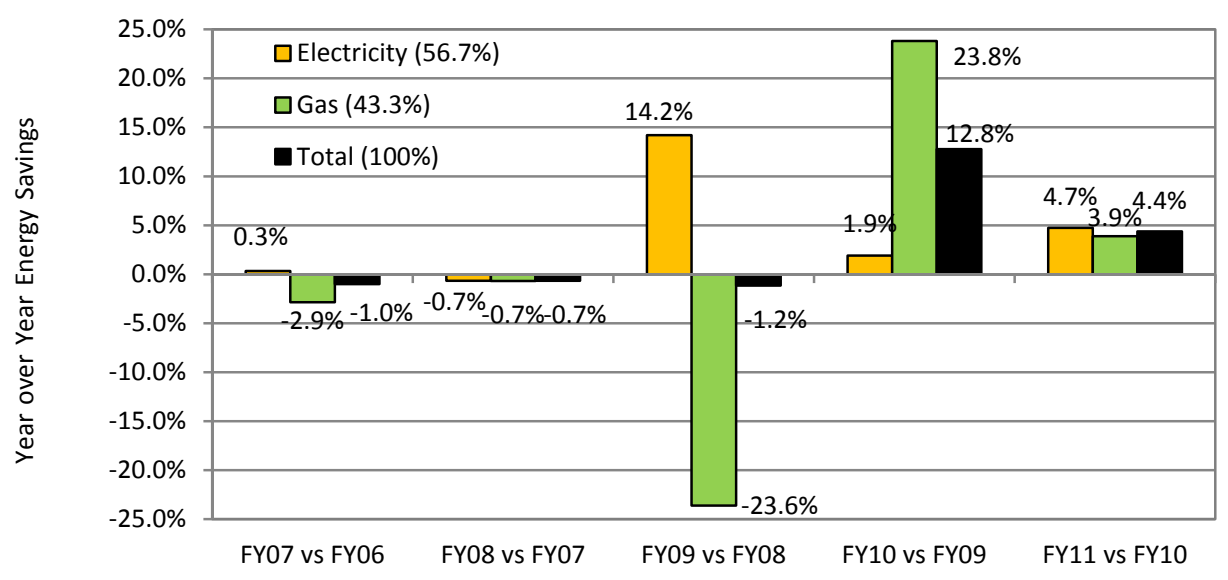

Figure 3: Weather-Corrected Energy Savings by Fuel Type at Neal Smith Federal Building

\subsection{Bannister Federal Complex}

The GSA Bannister Federal Complex in Kansas City, MO, includes two office buildings (Building 1 and Building 2) and six smaller outbuildings, totaling 1.54 million square feet. Buildings 1 and 2, which serve as the headquarters of GSA's Heartland Region, were the focus of the E4 training and field visit. Building 1 is about 1 million square feet, and Building 2 is about 300,000 square feet. While considered separate buildings at the site, these buildings are connected via large, open indoor hallways, and are thus essentially one building. Building 1 has a basement level and a ground level and takes up a massive footprint. Building 2 is three-stories above ground and is long and narrow.

The building mechanical systems are scheduled to operate on a regular weekly schedule of 6:00 a.m. to 6:00 p.m. Steam and chilled water/tempered water supplied from a central plant (owned and operated by an adjacent Department of Energy (DOE) facility) are used for space heating and cooling. In addition, there are three 100-ton chillers and seven Libert-type chillers for data centers. Building 1 has 20 air 
handlers and Building 2 has 5 air handlers, serving more than 100 variable-air-volume boxes and 100 fan/coil boxes along the perimeter.

The original E4 site visit for the Bannister Federal Complex was conducted April 2009. There were about 18 low-cost/no-cost and 20 capital project recommendations provided to the site. Figure 4 shows the status of 29 recommendations for which feedback was obtained from the follow-up interviews, excluding all capital project recommendations that were not considered. Each of these recommended measures and the implementation detail are listed in Appendix A (Tables 8 and 9). Most of the measures are identified to have low energy impact because of the large footprint of the facility. Those measures that have been implemented are clustered toward the left side of the chart (low-cost/no-cost). The only measure with a higher cost that has been implemented is the installation of occupancy sensors for corridor lighting throughout all of the hallways in Buildings 1 and 2. The other two higher impact measures were: (i) moving the building's outdoor air-humidity sensor away from the steam outlet which enabled economizing to take place for all of the building's air handlers; and (ii) a concerted effort by the staff to keep the large rollup bay doors closed when they are not being used.

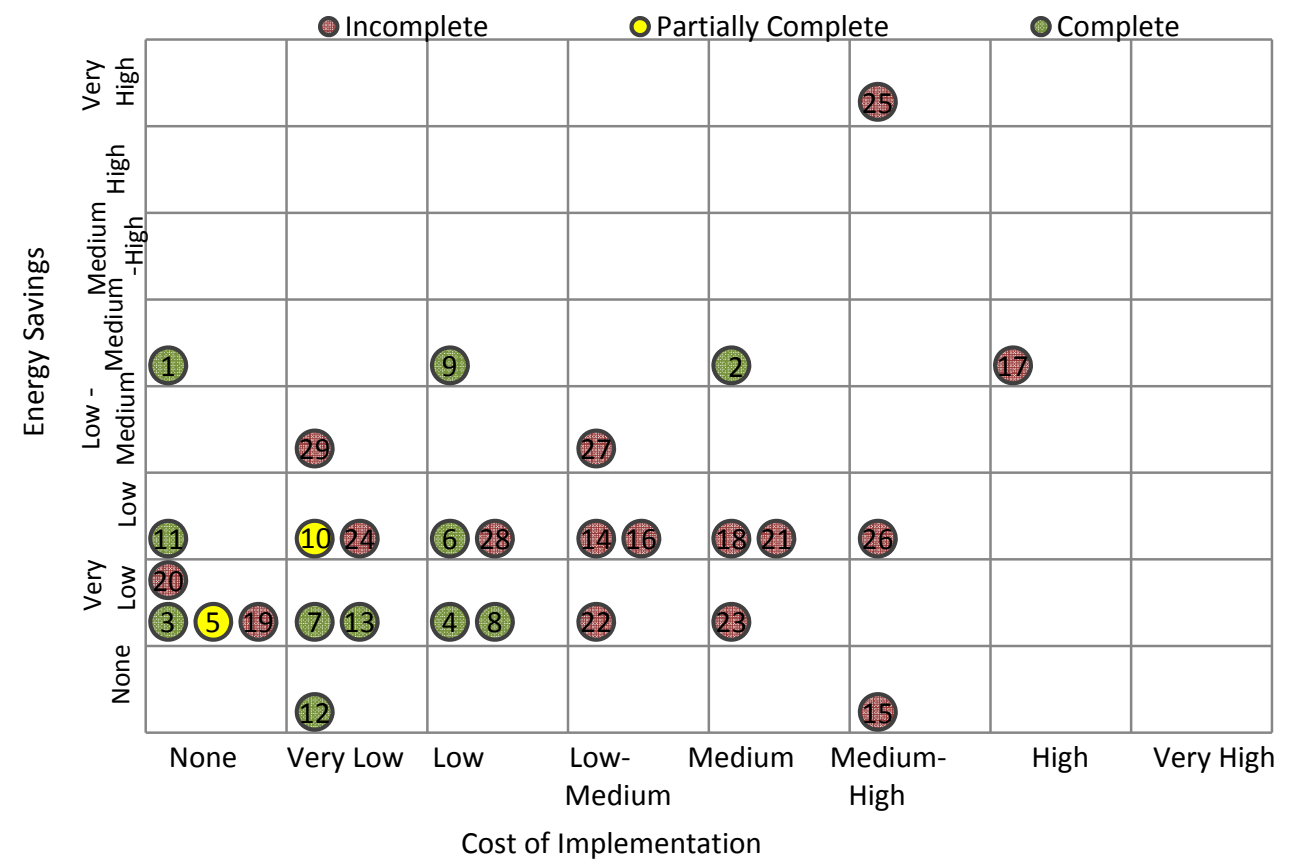

Figure 4: Implementation Status of E4 Recommended Measures at the Bannister Federal Complex

As Figure 5 shows, the Bannister Federal Complex has reduced its energy consumption by about 24\% between FY08 to FY11, which is the greatest energy savings during that period of all the eight buildings audited. Figure 5 also shows that more than half of that savings occurred prior to the E4 visit in April 2009, implying that there were significant changes to the building systems. Thereafter, total energy consumption was flat the following FY before dropping by 9\% in FY11. This is significant, considering that through the first 6 months of FY11, weather-corrected energy consumption was the same as FY10. All of the reduction in energy consumption occurred during spring and summer months of FY11. Part of this savings is to the result of vacancies that took effect in July 2011. Figure 6 shows that there has been a continuous trend of savings in chilled water from year to year since the E4 visit. Chilled water consumption is now about half of what it was in FY08. Steam consumption, which accounts for the majority of site energy consumption, declined by $14 \%$ in FY09, by less than $2 \%$ in FY10, and by $8 \%$ in FY11. Electricity consumption remained the same until FY11, when it dropped by $7.7 \%$. 


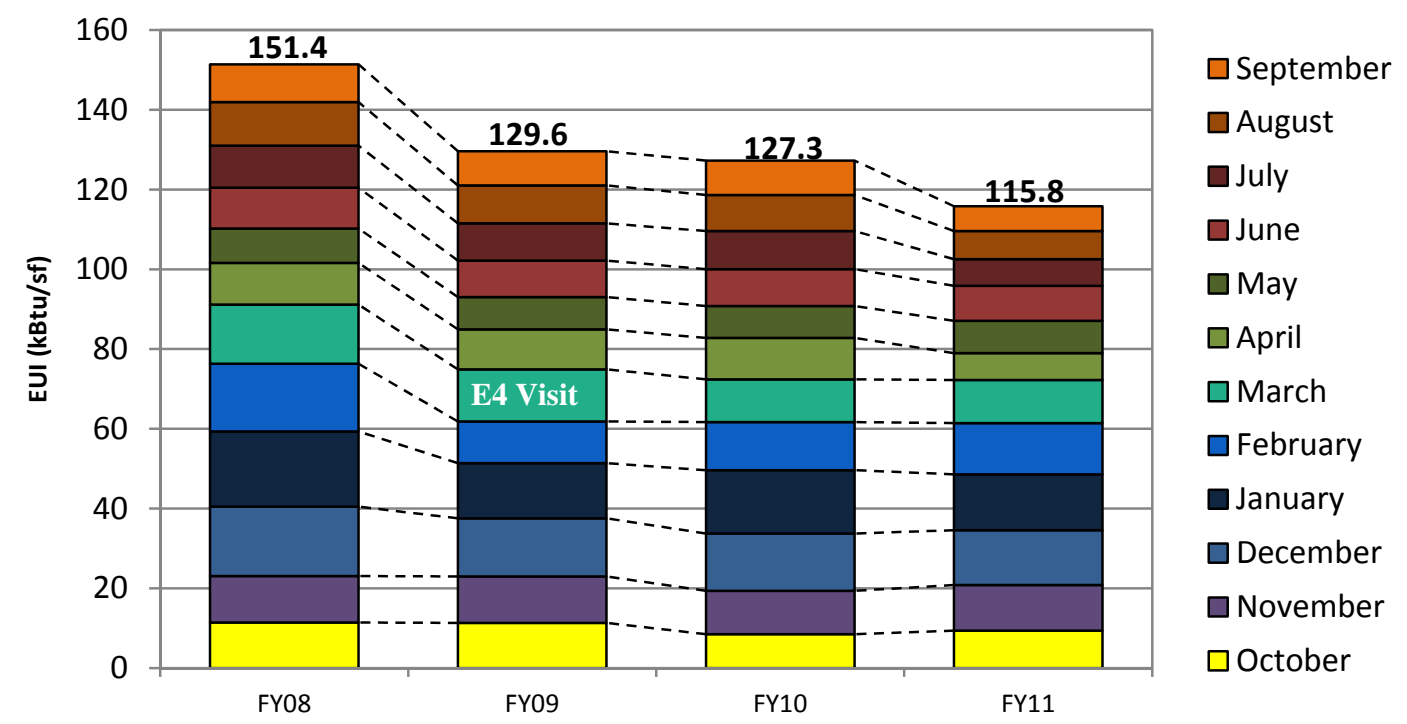

Figure 5: Annual and Monthly Weather-Corrected EUIs at the Bannister Federal Complex

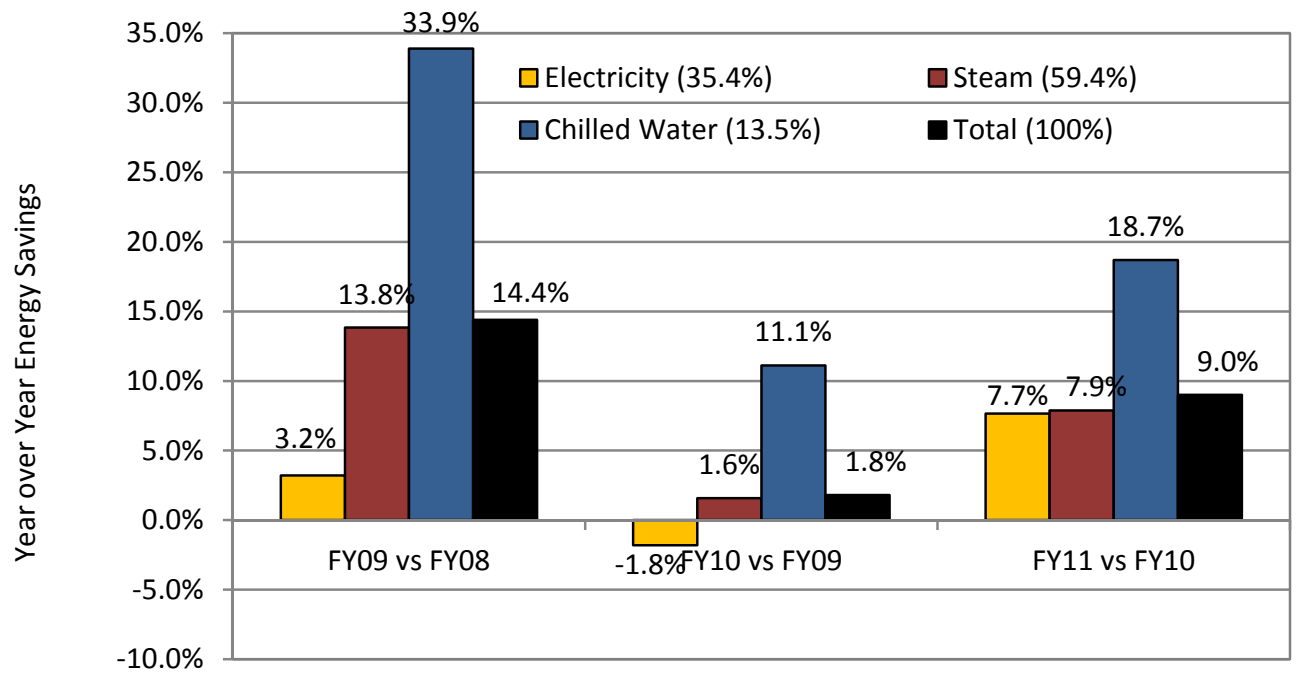

Figure 6: Weather-Corrected Energy Savings by Fuel Type at the Bannister Federal Complex

There are two key challenges at the Bannister Federal Complex that have limited the implementation of some of the recommended measures. First, the future of the facility is uncertain. It is possible that the operations at the Bannister Federal Complex will be moving to a different location within the next few years. While building staff are very concerned with saving energy, the uncertainty of long-term occupancy of this facility has had an impact on any recommendations that require even minimal capital investment. Any measures perceived to have longer paybacks simply do not warrant immediate consideration if the building is decommissioned in a few years. Another limitation is that only Building 2 has HVAC systems well connected and controlled by the JCI Metasys building automation direct digital control (DDC) system. Building 1, representing most of the square footage of the site, has much more sporadic digital control. This means that controls measures that can typically be applied to an entire building elsewhere can only be applied to a fraction of this site. 
The site had implemented most of the low-cost/no-cost E4 recommendations after the initial visit, resulting in savings of about $11.0 \%$ since the initial E4 site visit. However, this savings estimates may not be accurate because the energy use for steam and chilled water are not metered. The adjacent DOE complex, which administers the district steam and chilled water plants, estimates the Bannister consumption with an energy model. Hence, the E4 savings could not be accurately verified. A more detailed review of the E4 recommendations and follow-up visit to the Bannister Federal Complex is discussed later in Section 4.

\section{3 lowa City Federal Building}

Built in 1974, the Iowa City Federal Building is a three-story building with a basement. This is a multipurpose facility with offices, public access areas, and laboratories. The primary tenants are the U.S. Postal Service, U.S. Geological Survey, Veterans Health Administration, and Social Security Services. The gross floor area of the building is 98,720 sf. The building has a fully glazed wall in the front lobby and has significant window areas in exterior walls. The building is occupied generally on a weekday schedule of 9:00 a.m. to 5:00 p.m. for most office areas, except some of the U.S. Postal Service areas, which are operated 24/7. The number of building occupants is estimated at 200, excluding visitors.

The heating system consists of two low-pressure boilers with one heat exchanger. The boilers are operational from fall through spring, and are locked out of operation manually. There are two hot water pumps serving the VAV boxes, unit heaters, and perimeter radiators. The cooling system consists of two, 150 -ton chillers with one cooling tower on the roof. The chilled water system is active from spring through fall, and kept out of operation when the outside temperature is below $60^{\circ} \mathrm{F}$. There are six airhandling units (AHU), three heating ventilating (HV) units, and five exhaust fans. JCI Metasys is the building control system used to control the chiller, boiler, AHUs, HVs, and exhaust fans.

The E4 training and field visit was conducted in December 2009. The E4 team identified 16 low-cost/nocost and 6 capital project recommendations. The low-cost/no-cost recommendations included revising the air-handling unit operational schedule with optimal start strategies, exhaust fan schedules, chilled water set point reset, and boiler operating strategies. Other recommendations included replacement of failed VAV pneumatic controls, upgrading the lighting fixtures and automatic controls in the lobby area, replacement of the boiler and replacing the solar water heater panels.

A follow-up interview with the site staff was held in January 2011. A brief description of the measures and implementation details are provided in Appendix A (Tables 10 and 11). Figure 7 shows a bubble chart indicating the implementation status of the various E4 measures. It can be observed that all lowcost measures except two have been implemented and three medium-cost/capital projects remain to be addressed. 


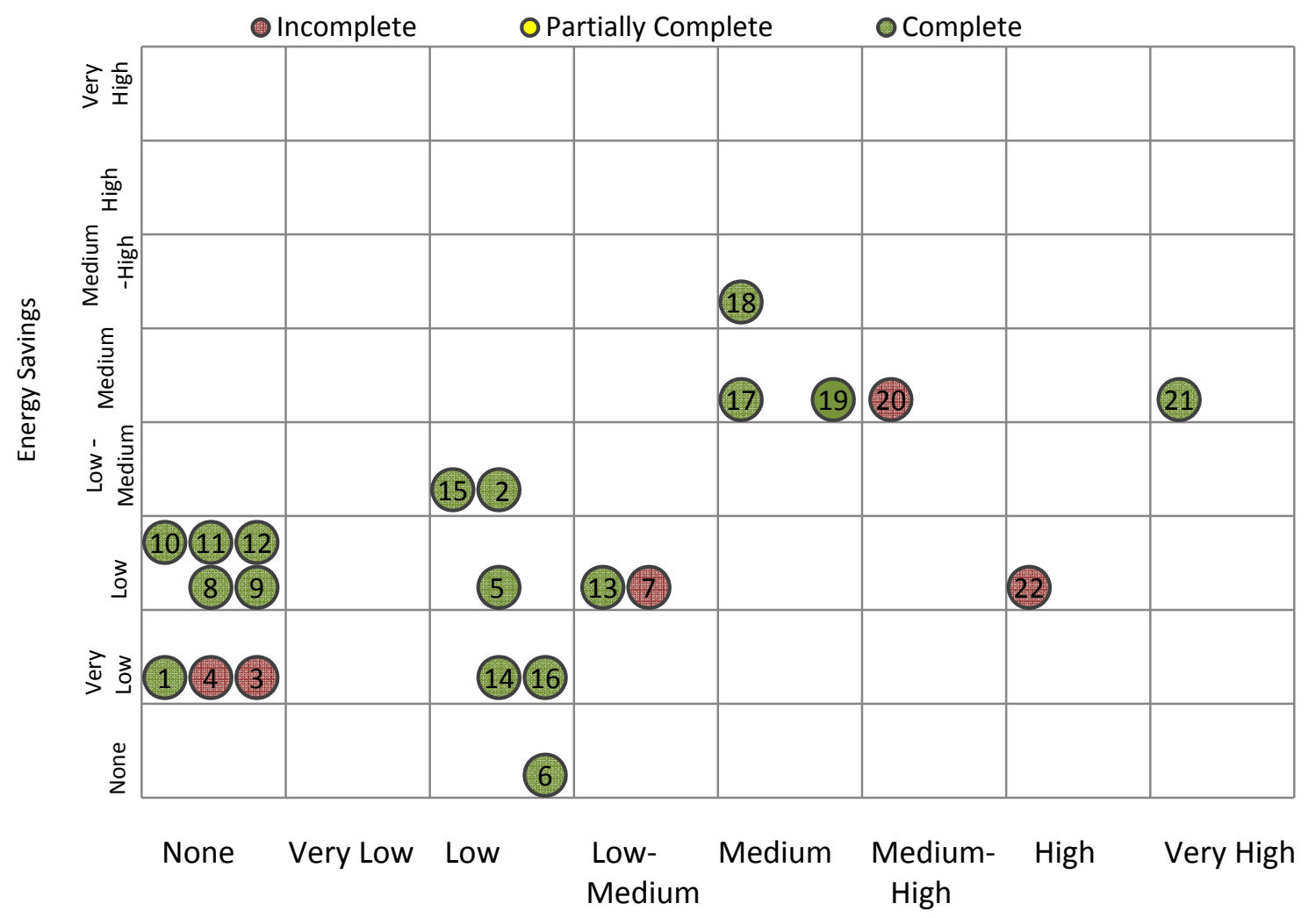

Cost of Implementation

Figure 7: Implementation Status of E4 Recommended Measures at Iowa City Federal Building

Figures 8 and 9 show the annual energy use and savings by fuel type for the period of FY07 to FY11. In FY09, prior to the E4 visit, energy consumption for the Iowa City Federal Building had dropped by 8\%. Since the December 2009 E4 visit, however, there has been no significant change in either electricity or natural gas consumption. Figure 8 shows that weather-corrected EUIs have remained almost the same from FY09 to FY11. Figure 9 shows that electricity consumption increased in FY10 but was reduced to about its pre-E4 starting point in 2011. Reduced gas consumption in FY10 was negated by a larger increase in FY11, which may be attributed to the boiler replacement project completed in FY11.

This facility is currently undergoing extensive renovations from ARRA projects, which addressed several of the E4 recommendations. Some of the significant changes include replacement of hot water boilers, steam boilers, pumps, variable frequency drives (VFDs) and three air-handling units. In addition, the lobby lighting, doors and front glass were replaced as part of a front entry renovation. Although several of these projects are completed, the final commissioning of mechanical systems and some equipment installation work is in progress at the time of this follow-up study. Hence, the energy savings from E4 recommendations and renovations can be evaluated only in the later part of FY12. 


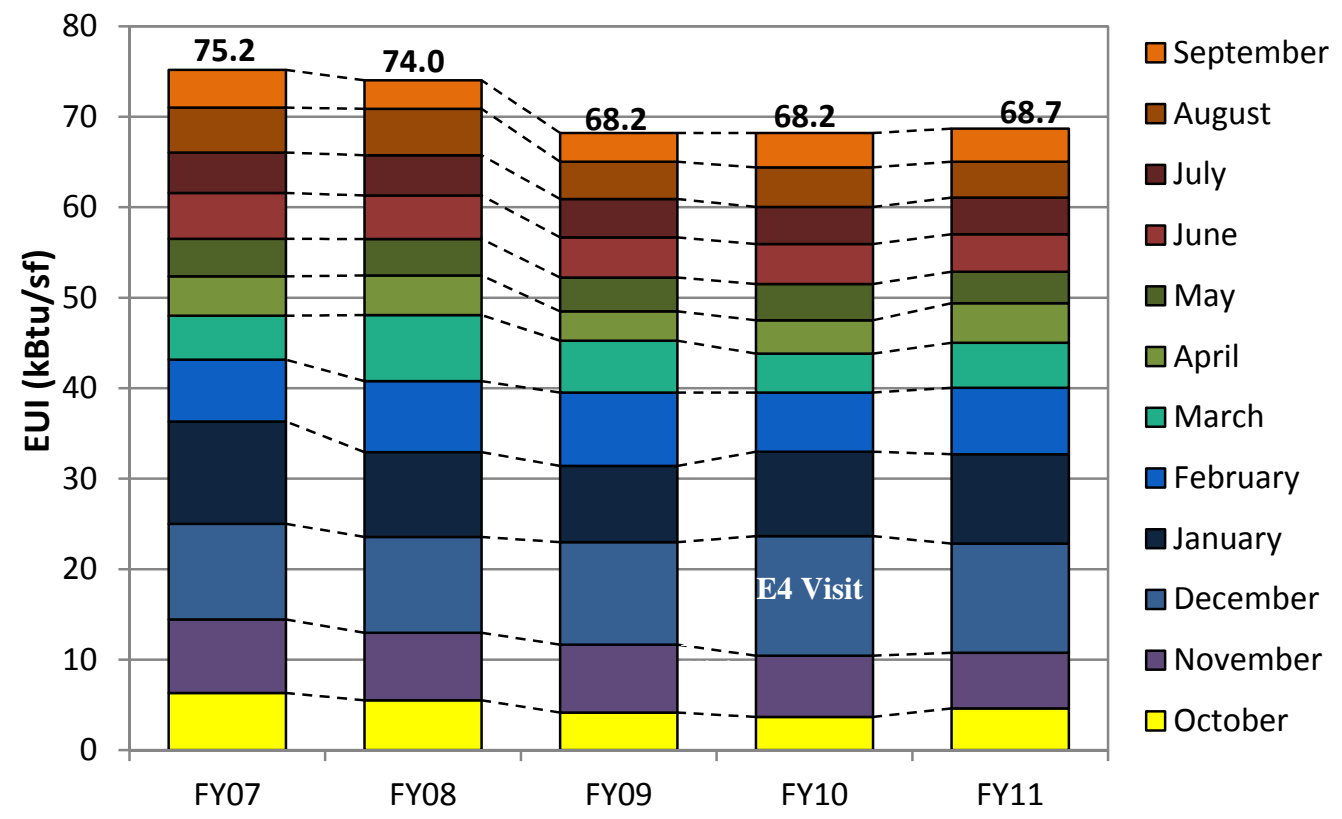

Figure 8: Annual and Monthly Weather-Corrected EUIs at Iowa City Federal Building

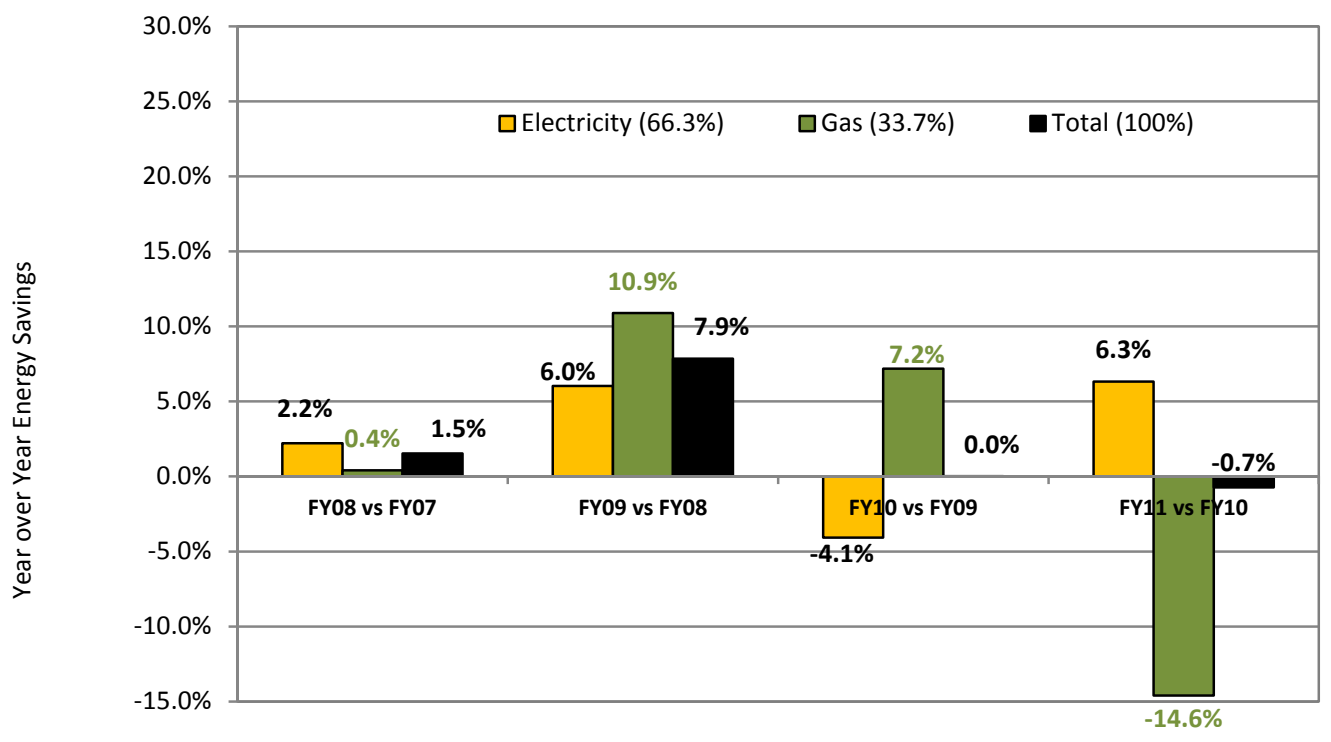

Figure 9: Weather-Corrected Energy Savings by Fuel Type at Iowa City Federal Building 


\subsection{Robert A Young (RAY) Federal Building}

Built in 1931, the RAY Federal Building located in St. Louis, MO is a 10-story office building with basement, and a 20-story tower in the North East corner. The E4 visit focused on the 10-story portion of RAY that is currently occupied with a gross floor area of 1,131,171 sf. Floors 11 through 20 of the 'tower' section are unconditioned and unoccupied. The building tenants include the U.S. Internal Revenue Service, U.S. Army Corps of Engineers, U.S. Marine Corps, and U.S. Coast Guard. This building has mostly office areas (including conference rooms), data centers, a cafeteria with vending machines, lounges and some public access areas. The building is occupied generally on a weekday schedule of 7:00 a.m. to 5:00 p.m. for most office areas, except for data center areas, which are operated 24/7. The number of building occupants is estimated at 3000 , excluding visitors.

The RAY Federal Building uses onsite chillers and building water loop to provide chilled water to three air handlers that each serve an entire quadrant of the building. (It is an L-shaped building with three quadrants.) Three quadrant fans in the penthouse provide supply ventilation air for the building, which is distributed through one of three VAV networks. Heating is supplied by perimeter baseboard heaters. Computer room air conditioning (CRAC) units provide conditioned air to data centers.

The RAY Federal Building E4 field audit and training was conducted in February 2010. During that time, building staff were planning for significant upgrades to envelope, lighting and mechanical systems using ARRA funding. The envelope upgrade included weatherizing doors and replacing the building's single-pane windows with double-pane windows, and the mechanical upgrade project included a BAS upgrade, re-commissioning (including advanced control algorithms), a new four-stage chiller, plus economizers for the CRAC units. These ARRA projects addressed most of the E4 recommendations, although the E4 report did not directly contribute to the development of ARRA projects.

PNNL interviewed RAY Federal Building staff in January 2011 to review the status of each of the recommended measures from the E4 report. Appendix A (Tables 12 and 13) provides the list of measures and a brief detail of the implementation. Figure 10 shows a bubble chart indicating implementation status of these measures, which shows that the vast majority of the measures (18) have been fully or partially implemented, and about five measures remain unimplemented. The RAY Federal Building is in the final stages of completing all ARRA projects. These projects have been ongoing for $1 \frac{1}{2}$ years. Some of the projects (especially the window replacement) were disruptive during the implementation phase, and have led to an increase in energy consumption in the interim because of 24/7 operation of mechanical systems in some areas. RAY staff expect that it will take a few more months of adjustments and debugging the control system before the building will be running smoothly again. It is anticipated that calendar year 2012 energy consumption will provide the first real annual energy use data that can be used to assess the impact of E4 measures and the additional ARRA projects in reducing energy consumption at the RAY Federal Building.

One recommendation that stands out from the chart is a capital project opportunity that was not included as part of the ARRA project, but has potentially high energy-savings associated with it. This measure is a recommendation to reinstall the zone thermostats so that the VAV system and baseboard heaters cannot run at the same time, and so the VAVs and baseboard heaters for any given zone are controlled from the same thermostat. The E4 team believes that there may still be significant energy savings to be realized from this measure. 


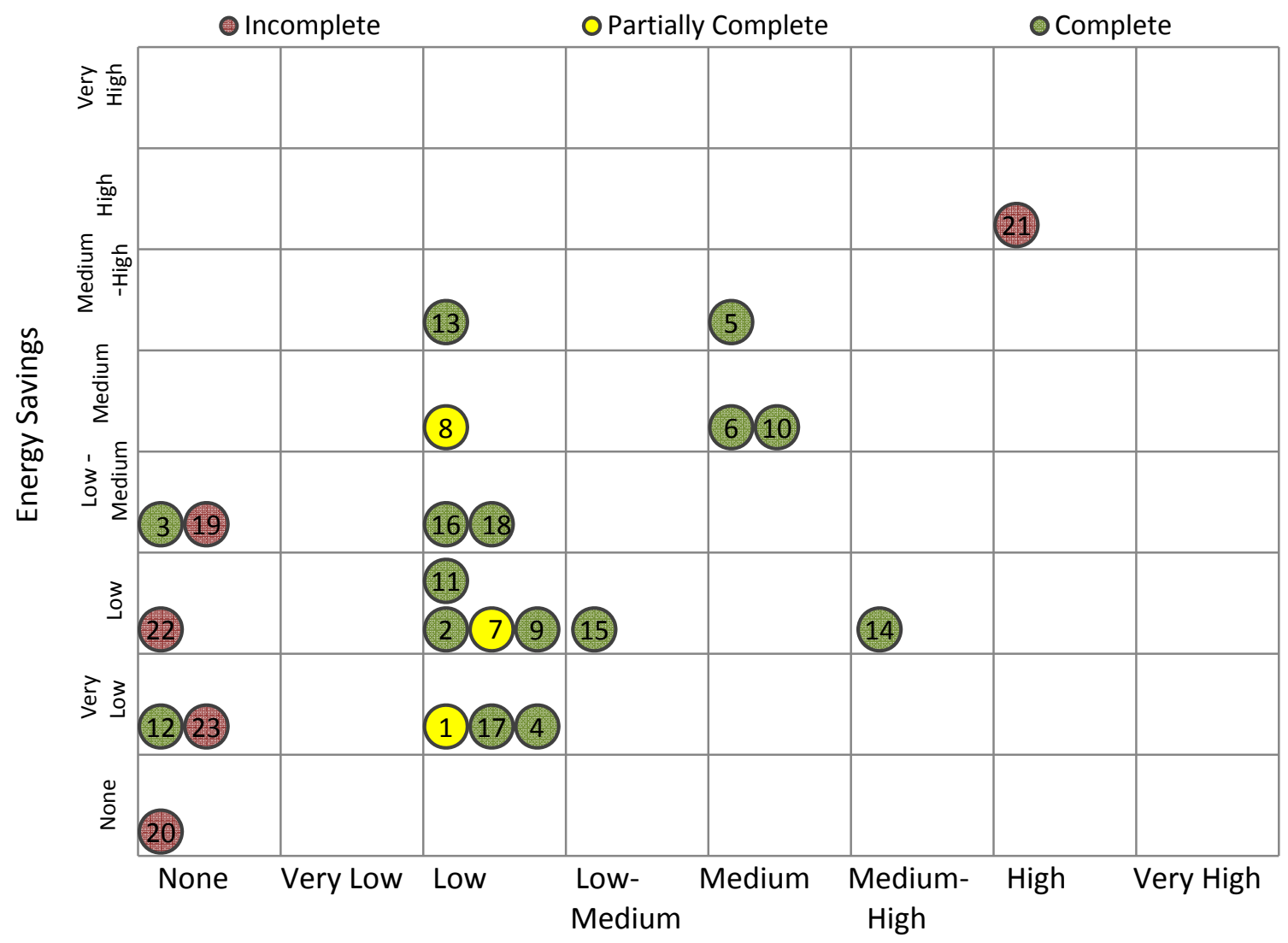

Cost of Implementation

Figure 10: Implementation Status of E4 Recommendations at RAY Federal Building

RAY Federal Building energy consumption since the E4 visit in January 2010 remains the same as before the E4 visit, as shown in Figure 11. Figure 12 shows that electricity, which makes up 97\% of site energy consumption, increased by $2 \%$ in FY10, and then decreased by $0.7 \%$ in FY11. Because the RAY Federal Building is just now finishing a number of retrofit projects, the impact of E4 recommendations can be seen in the FY12 annual energy use. The situation in the RAY Federal Building is somewhat similar to that of the Iowa City Federal Building in terms of implementing the E4 measures; both facilities have not demonstrated any immediate savings, but have implemented these measures as ARRA projects that are nearing completion. Hence, a more definitive savings determination can be made after FY12. 


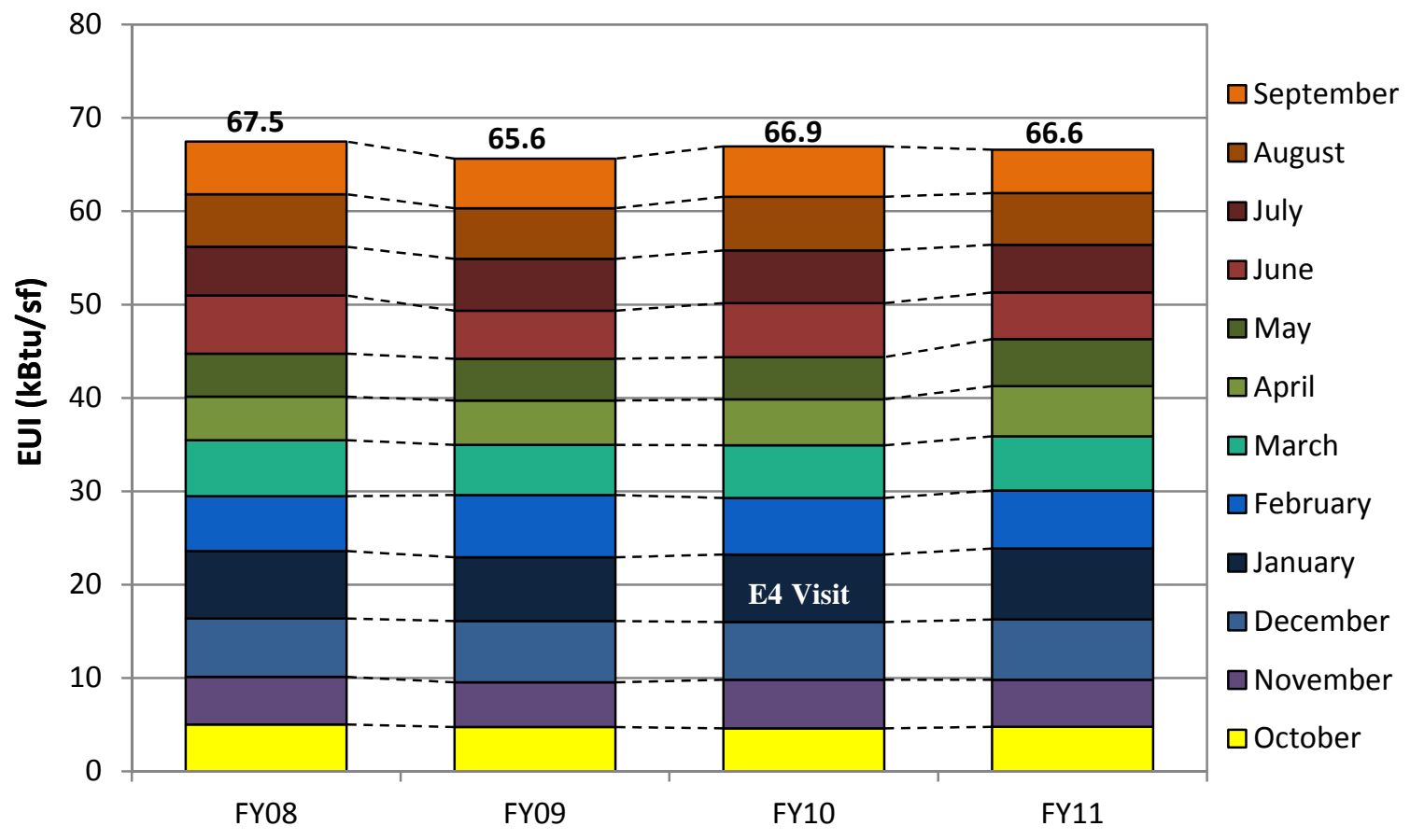

Figure 11: Annual and Monthly Weather-Corrected EUIs at RAY Federal Building

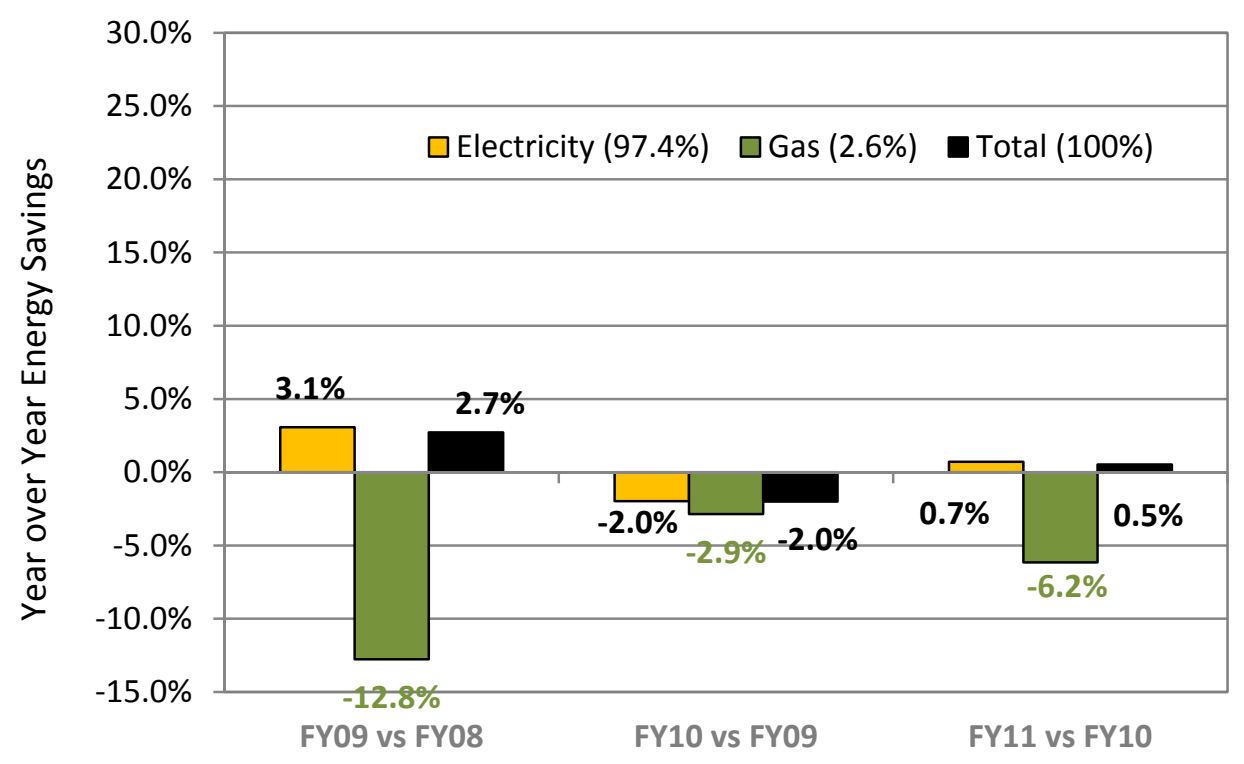

Figure 12: Weather-Corrected Energy Savings by Fuel Type at RAY Federal Building 


\subsection{Goodfellow Federal Center}

The Goodfellow Federal Center is situated in a 62.5-acre, 23-building campus in St. Louis, MO. The campus buildings were built in 1941 by the Department of Defense (DOD) and were utilized as an Army small arms munitions plant to support the World War II effort. In 1966, the ownership and operation of the buildings transferred from the Army to GSA, who renovated the complex into an office park. The Goodfellow Federal Center is eligible for listing on the National Historic Register. The primary building tenants include the U.S. Department of Agriculture (USDA) and the Farm Service Agency.

The gross square floor area of buildings in this campus is 1,800,854 sf. The majority of the buildings are two-story with brick exterior. The E4 visit focused on Building 105, which has a gross floor area of 225,000 sf. The building is occupied from 6:00 a.m. to 9:00 p.m., Monday through Friday, and Saturdays approximately 8 hours; but the USDA labs, which occupy about $25 \%$ of the building, may be occupied 24/7. The mechanical system includes 2 steam boilers, 4 chillers (two 350-ton, one 550-ton and another 250-ton), 8 roof-top air houses, 50 exhaust fans and 260 VAV boxes. The building control system is provided by American Auto-Matrix for controlling the schedules and outdoor air lockouts for all mechanical equipment.

The E4 team visited the site and provided training to Goodfellow Federal Center facility managers and O\&M staff in March 2010. A total of 24 recommendations were provided to the facility, which included 20 low-cost/no-cost recommendations and 4 capital cost projects. Building staff at Goodfellow Federal Center were interviewed in December 2011 about changes made to their facility following the E4 visit and report. Appendix A (Tables 14 and 15) provides a brief description of the measures and implementation details. Figure 13 is a bubble chart that summarizes the implementation status of the measures. The chart shows that for Goodfellow Federal Center Building 105, about 10 measures are fully implemented, 6 measures are partially implemented, and 8 measures have not been implemented.

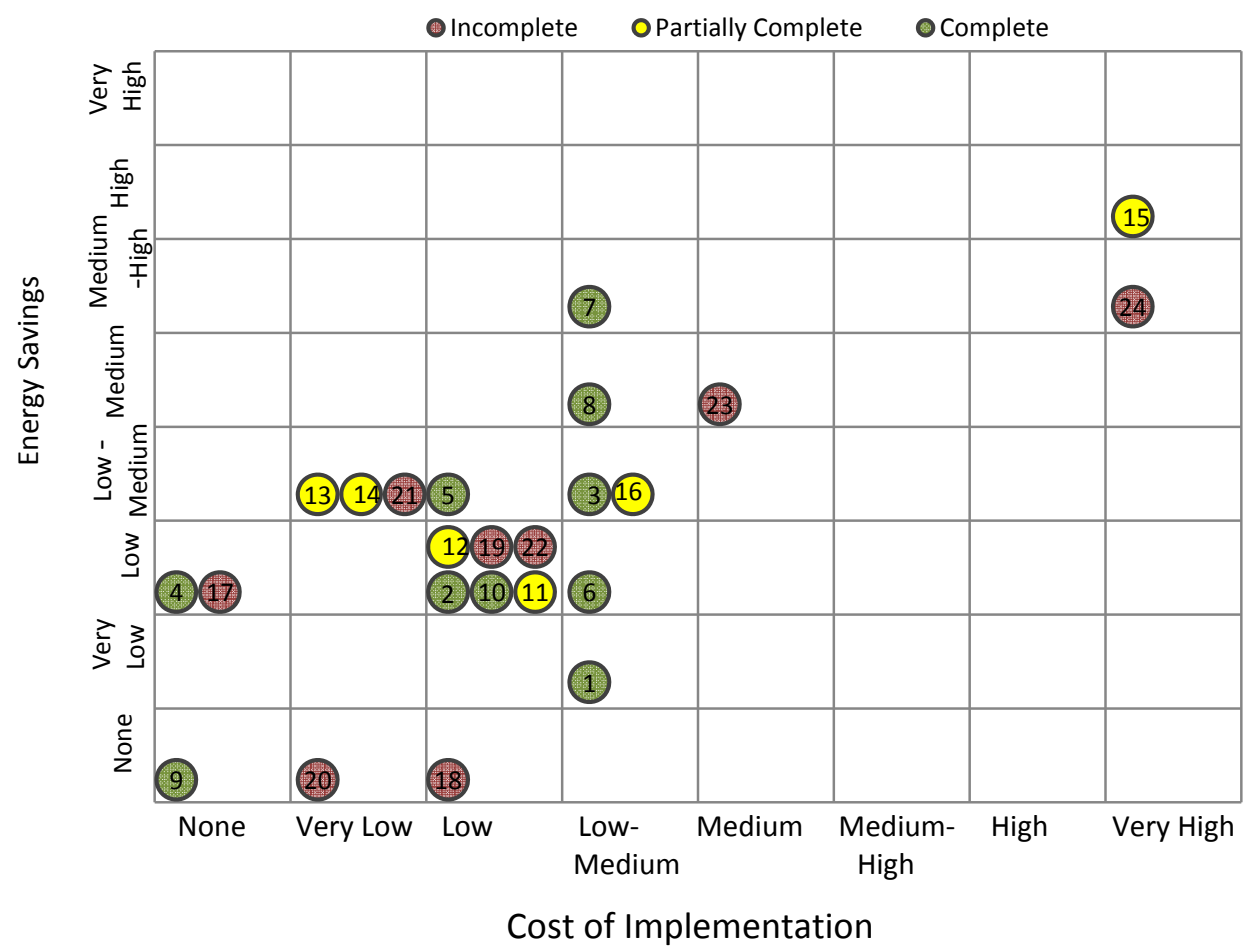

Figure 13: Implementation Status of E4 Recommendations at Goodfellow Federal Center Building 105 
The building audited by the E4 team is one of many in the Goodfellow Federal Center campus. None of the buildings in the campus are sub-metered, so the data available on energy consumption is of limited use in gauging the effectiveness of E4 recommendations for Building 105. In general, the Goodfellow Federal Center has been experiencing significant increase in energy consumption since FY08 until FY10, as shown in Figure 14. It is important to note that electricity consumption has increased steadily since FY08, while gas consumption has decreased, as shown in Figure 15. It is unlikely that this complex-wide trend can be used for assessing the impact of E4 recommendations for Building 105.

Of all the implemented measures, HVAC air-side measures provide the highest energy impact. There are many HVAC controls measures among the partly implemented measures, indicating that the staff may be having difficulty with implementing control system changes. None of the buildings on the site are independently sub-metered, which presents a challenge in quantifying savings for Building 105.

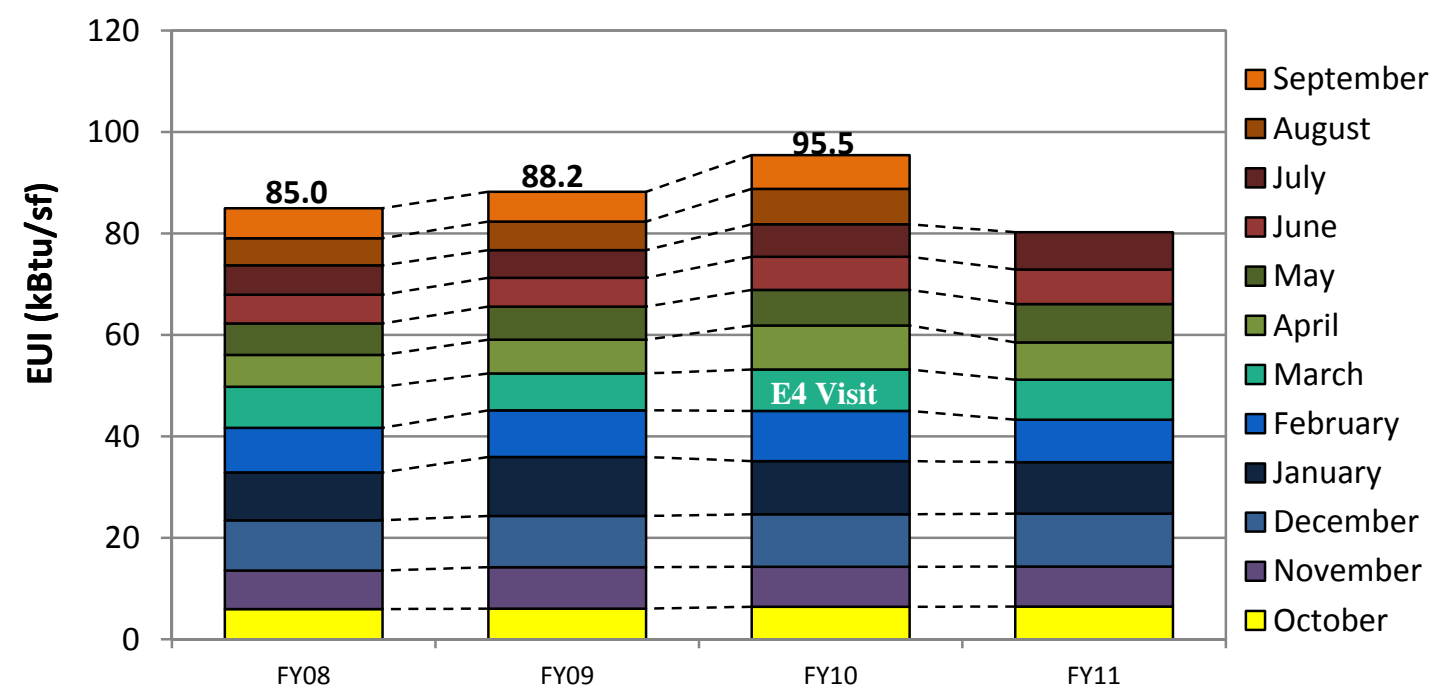

Figure 14: Annual and Monthly Weather-Corrected EUIs at Goodfellow Federal Center

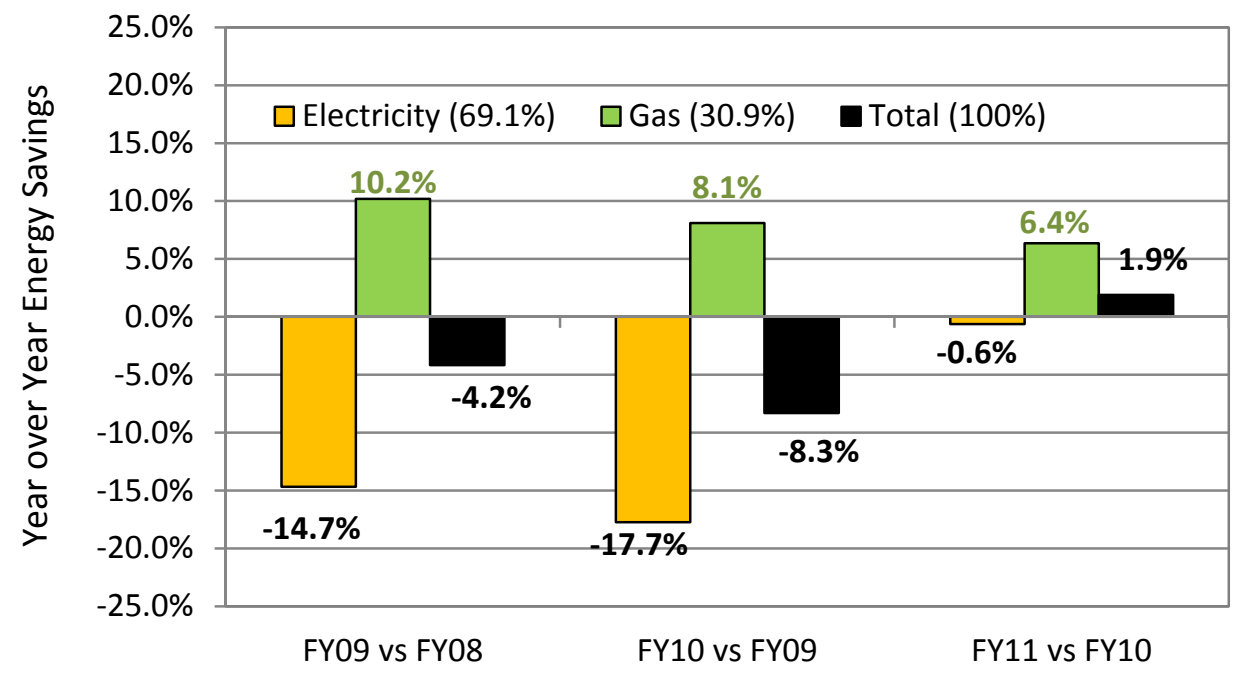

Figure 15: Weather-Corrected Energy Savings by Fuel Type at Goodfellow Federal Center 


\subsection{Frank Carlson Federal Building and Courthouse}

Frank Carlson Federal Building and Courthouse in Topeka, KS is a four-story building with gross floor area of 232,459 sf., primarily occupied by the U.S. Department of Justice. The building is square in shape, with a large central atrium. Main HVAC system air handlers each serve one quadrant of the building, although the $4^{\text {th }}$ floor and basement are served by other air handlers. Chilled water is produced onsite using two chillers. Perimeter electric heating fan-coil units provide all of the building heat. The Carlson Federal Building and Courthouse uses only electricity onsite.

The Frank Carlson Federal Building and Courthouse was originally visited by the E4 team on May 2010. The E4 report contained 16 low-cost/no-cost measures and 4 capital projects. The Carlson Building and Courthouse facility manager and O\&M staff were interviewed in November 2011 to assess the status of implementation of the E4 measures. Only four of the measures, as shown in Figure 16, had been implemented, and of those, at least two were incidentally addressed by an air-handler replacement project undertaken independent of E4 recommendations. PNNL recognized from the interview that although staff was clearly concerned with energy savings at the site, they had not used the E4 report to implement the recommended measures. It is unclear if this report was not reviewed because of personnel changes in the O\&M staff, or they were focused on the air-handler replacements during the past year.

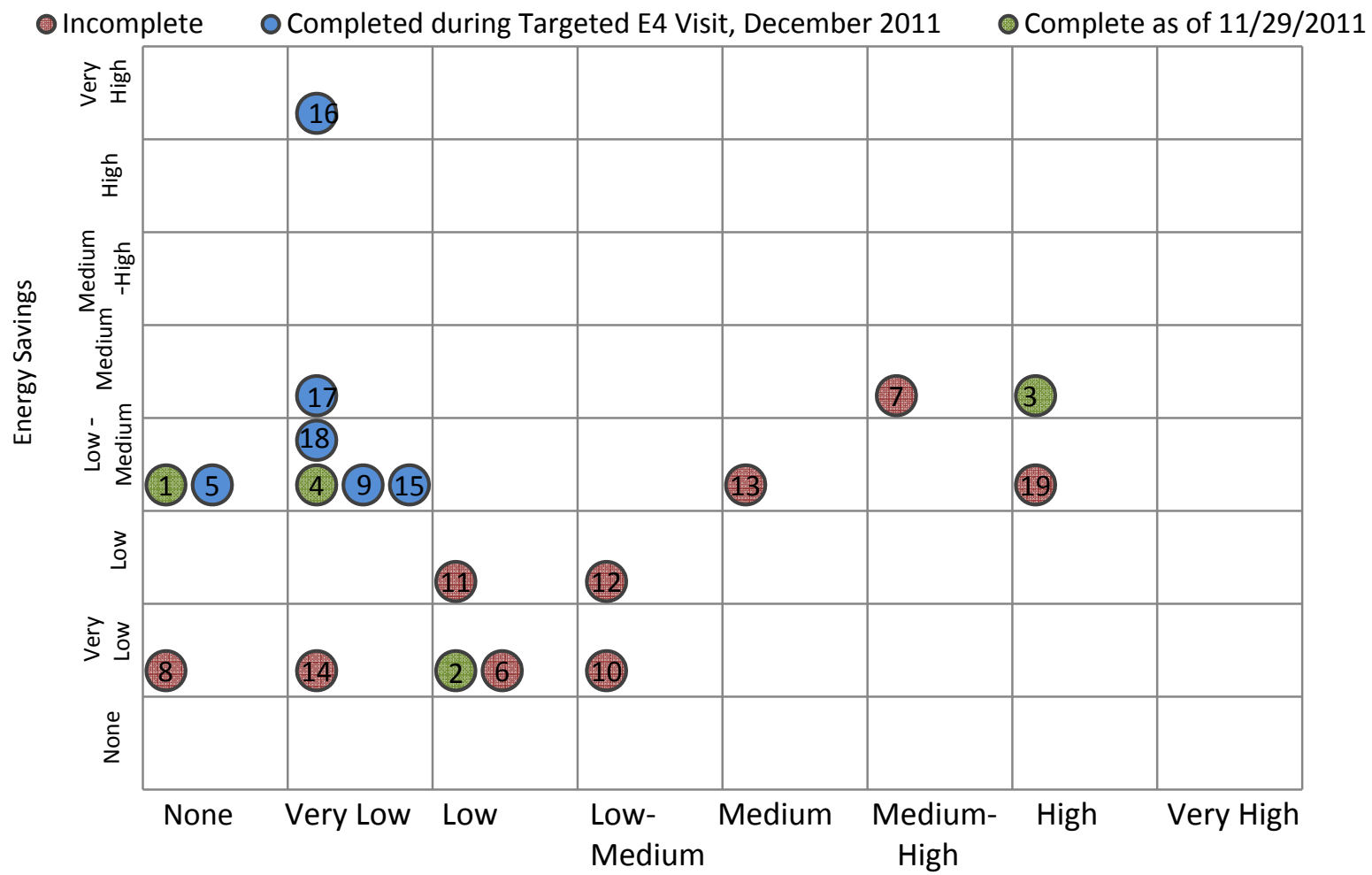

Cost of Implementation

Figure 16: Implementation Status of E4 Recommendations Implemented at Carlson Federal Building and Courthouse

Based on the regional office recommendation, the Carlson Federal Building and Courthouse was selected to be one of the two sites for a follow-up visit in December 2011 along with a targeted-E4 effort to implement advanced control system measures. More details of this follow-up visit are discussed in 
Section 4. Figure 16 shows the current status of all the E4 recommendations at the Carlson Federal Building and Courthouse facility. The green colored measures were implemented by Carlson staff prior to the E4 follow-up interview, and the blue measures were implemented by PNNL as part of the targetedE4 project. This chart shows that most of the low-cost, higher impact measures have been implemented, but there are several additional recommendations that are yet to be implemented. Appendix A (Tables 16 and 17) provide a list of all the recommended measures and current status of implementation.

The first E4 visit at the Carlson Federal Building and Courthouse took place in April 2010, in the middle of FY10, when the energy consumption was almost the same as the previous two fiscal years, as shown in Figure 17. Figure 18 shows that in FY11, there was a significant drop in energy consumption (6.3\%), which is mostly caused by replacement of the facility's older air handlers and terminal units. Further discussion on the estimated energy savings from the recent targeted-E4 effort is discussed in Section 4.

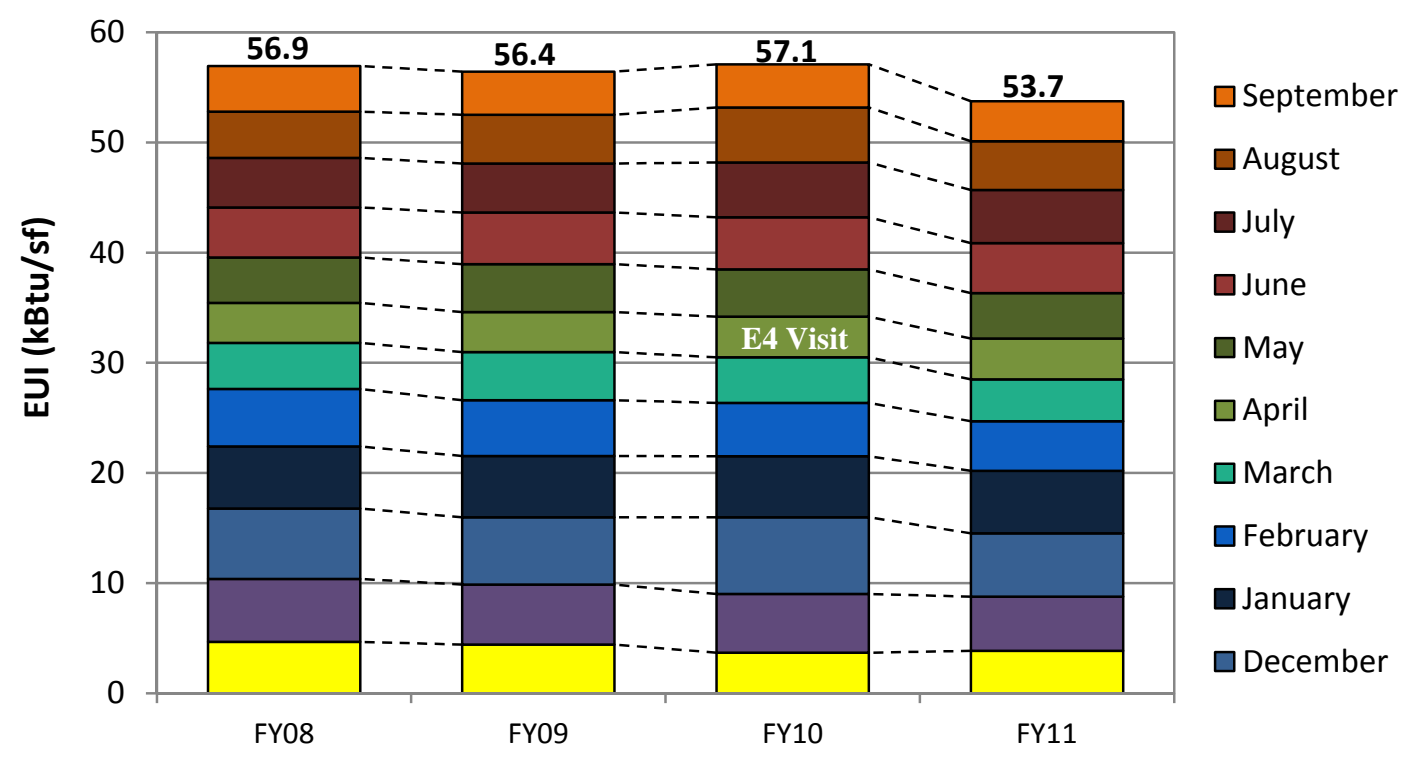

Figure 17: Annual and Monthly Weather-Corrected EUIs at Carlson Federal Building and Courthouse 


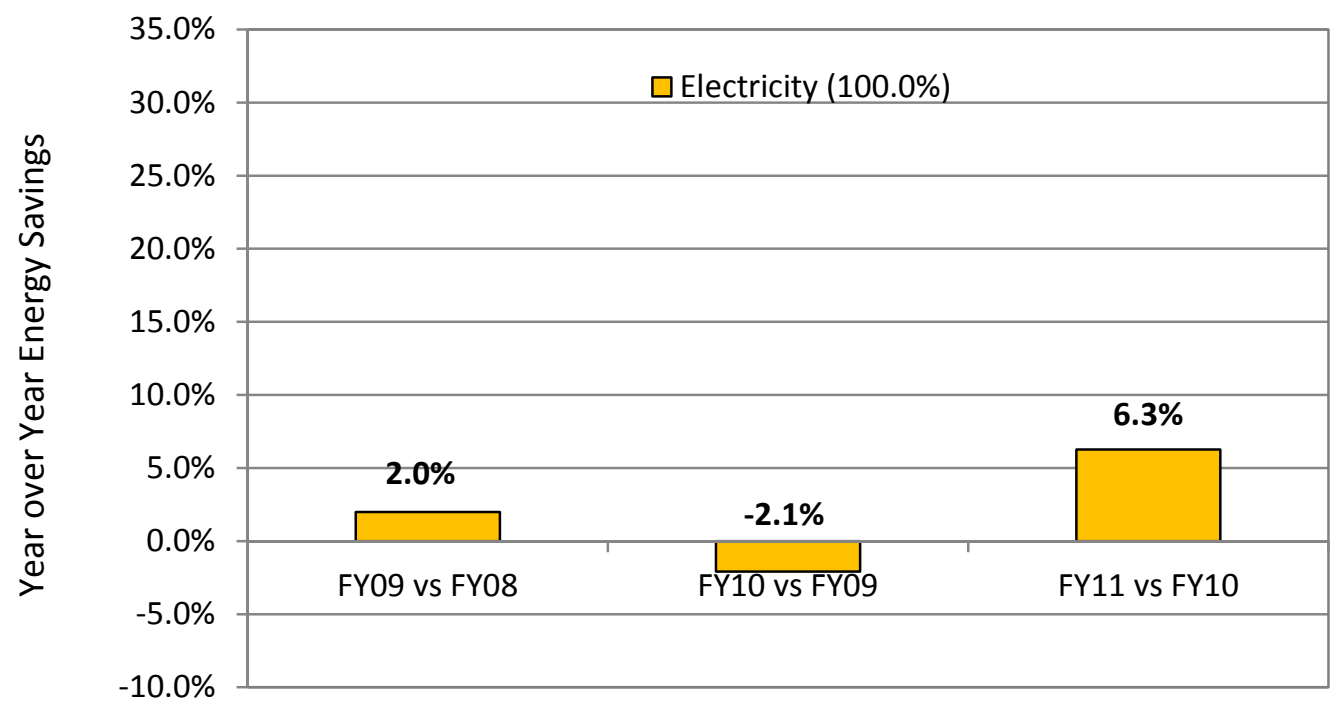

Figure 18: Weather-Corrected Energy Savings by Fuel Type at the Carlson Federal Building and Courthouse

\subsection{Charles Evans Whittaker U.S. Courthouse}

Built in 1998, the Charles Evans Whittaker U.S. Courthouse (Whittaker Courthouse) is located in Kansas City, Mo. This is a 13-story building with 11 stories above grade with a crescent-shaped floor layout and curved exterior walls. The front side of the building has full-story, high-glazed atrium/lobby (south facing) on floors 3 through 8 , and the entire north façade is fully glazed. The gross floor area of the building is 753,510 sf., and it is primarily occupied by the U.S. Department of Justice. The building operates on a weekday schedule of 7:30 a.m. through 6:00 p.m. The number of building occupants is estimated at 400 , excluding visitors.

The heating system consists of four shell-and-tube heat exchangers operating in series with rated input capacities of $20 \mathrm{Mlb} / \mathrm{hr}$, hot water base board heating along perimeters, and variable-air-volume (VAV) terminal boxes equipped with hot water reheat coils. The cooling system consists of two 750-ton and one 250-ton chillers, three cooling towers with two tower fans rated at $50 \mathrm{hp}$ and one rated at $15 \mathrm{hp}$. There are 52 air-handling units (AHU) with hydronic heating and cooling coils. The building control system is a SIEBE direct digital control (DDC) system controlling all the building HVAC systems.

The E4 team conducted onsite classroom training, field training and site audit in June 2010. An E4 report was provided to Whittaker Courthouse staff containing recommendations for 15 low-cost/no-cost measures and 4 capital projects. Whittaker Courthouse staff were interviewed in January 2012 to review the progress made in implementing E4 recommendations. Figure 19 shows a bubble chart depicting the implementation status of the measures. Appendix A (Tables 18 and 19) provides a list of measures and a brief detail of the implementation. While several low-cost/no-cost measures have been implemented, the many other low-cost measures are still unimplemented. The highest impact measures that have been implemented include extensive lighting upgrades (to LEDs) as well as de-lamping and better control of lighting, plus an optimization of HVAC schedules, which has reduced the fan operating hours by additional 45 minutes/day. 


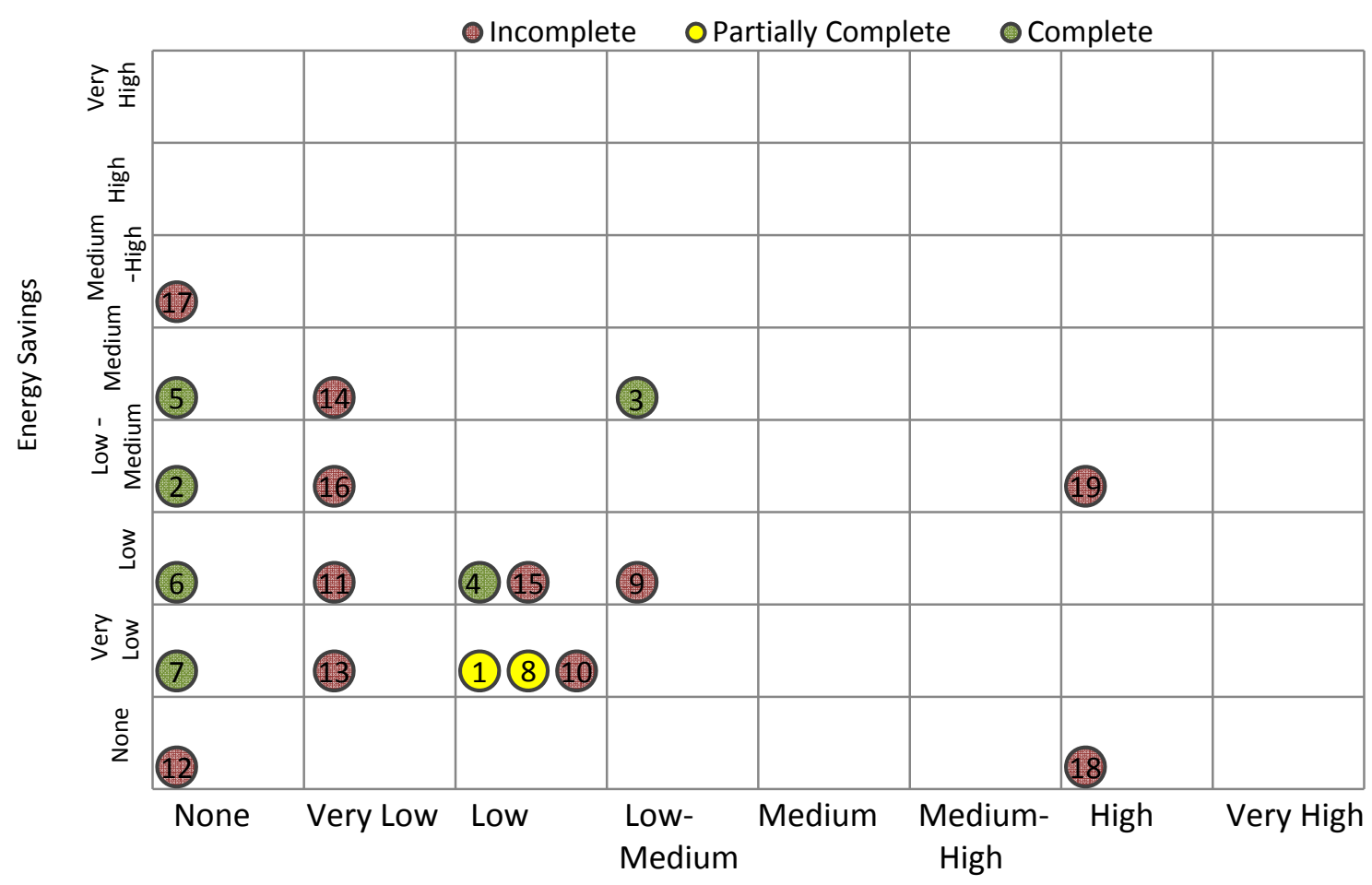

Cost of Implementation

Figure 19: Implementation Status of E4 Recommendations at Whittaker Courthouse

Figure 20 shows that at the time of the E4 visit (June 2010), the Whittaker Courthouse was already beginning to reduce their energy consumption after a 3-year trend of increasing energy consumption. Figure 21 shows that the modest increase in energy consumption in FY08 was due to increased electricity use, while the larger increase in FY09 was due to 15\% rise in weather-corrected steam consumption. FY10 saw a moderation in energy consumption at the Whittaker Courthouse, mostly due to reduction in steam consumption from the prior year. There was a larger drop in energy consumption in FY11, led again by decreasing steam consumption, this time by 14\%, compared to FY10. Energy consumption at the Whittaker Courthouse is now 12\% lower than the peak in FY09, and 3.7\% lower than in FY07.

The Whittaker Courthouse did not have any ARRA funded projects, and has been very cost-constrained in implementing many of the E4 recommended measures. However, there are two significant low-or no-cost measures that are not implemented. These include VAV discharge temperature reset and summer steam shutdown. Whittaker Courthouse staff indicated that some steam is needed in the summer for humidification required for the wood work and trims in the court rooms; however, this is not the case with typical commercial building practice in this climate. 


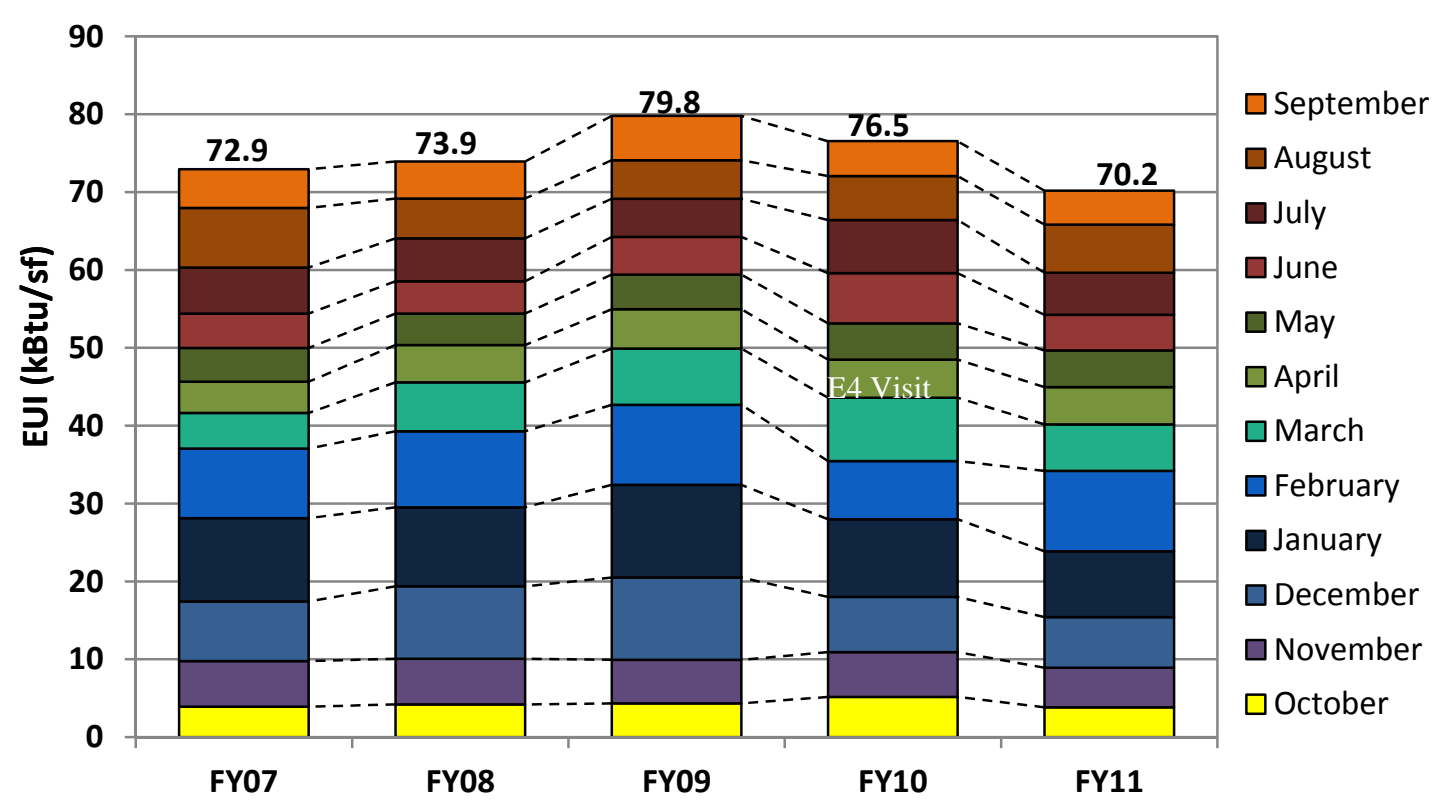

Figure 20: Annual and Monthly Weather-Corrected EUIs at Whittaker Courthouse

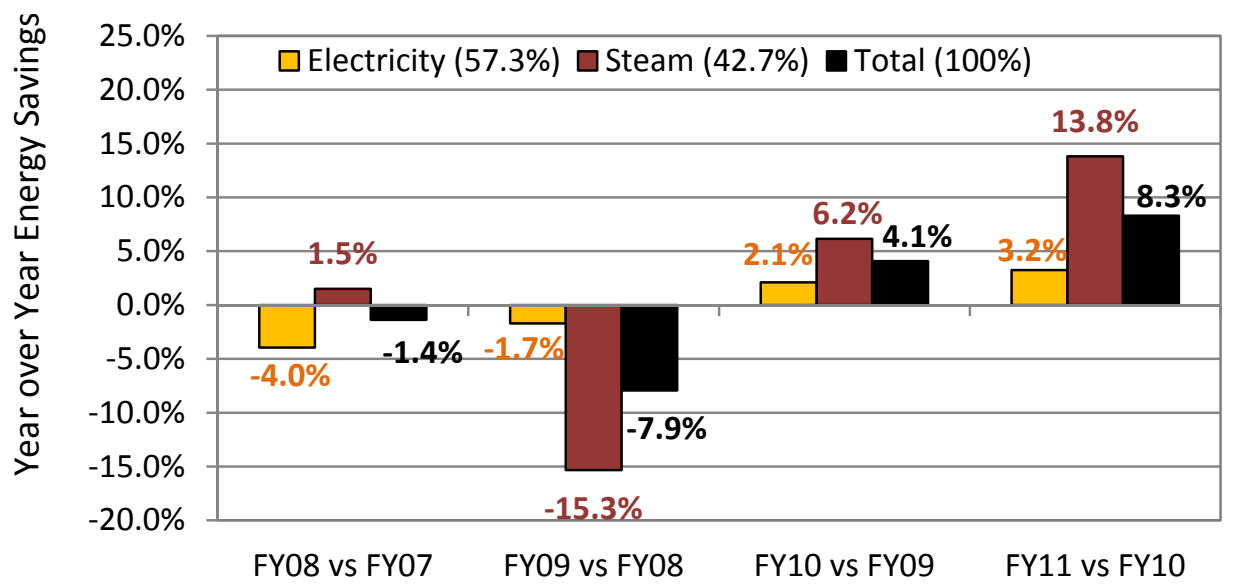

Figure 21: Weather-Corrected Energy Savings by Fuel Type at Whittaker Courthouse

\subsection{Edward Zorinsky Federal Building}

Originally built in 1959 and fully renovated and reoccupied in 2007, the Edward Zorinsky Federal Building (Zorinsky Federal Building) in Omaha, NE is a nine-story building with a basement, subbasement, and roof-level mechanical penthouse. This building has a window-to-wall ratio of about $60 \%$ and has various types of shading and light harvesting louvers. The gross conditioned floor area of the building is 415, 567 sf.., consisting of offices, data centers, a day care center, cafeteria, fitness center and conference rooms. Major tenants include U.S. Army Corps of Engineers, Internal Revenue Service, Department of Housing and Urban Development and U.S. Department of Agriculture. The number of building occupants is approximately 1,200 and typical occupancy schedule is 7:00 a.m. to 5:00 p.m. during weekdays (Monday through Friday).

The building uses district steam for space heating and district chilled water for space cooling. The hot water coils in VAV boxes provide heating, and the cooling coils in air-handling units provide cooling. 
Each floor has a dedicated air-handling unit that provides supply air to the zones. Return air is ducted back to the air-handling units from grills in the zones and in some cases using open plenums.

Additionally there are unit heaters in the loading dock area and direct expansion computer room air conditioning (CRAC) units in data centers. The building control system is Schneider TAC, used to control all heating, cooling and ventilation systems.

The E4 training and field audit was conducted in December 2010. The E4 recommendations included 12 low-cost and 6 capital project opportunities. Figure 22 shows the current state of implementation of these recommendations. About half of the recommendations were implemented, and the other half has not been implemented because of a lack of expertise for control system programming and funding. The lowcost/no-cost recommendations were focused on reducing simultaneous heating and cooling observed in the air-handling units and data center, schedule revisions, economizer control implementation and staging of hot water pumps. After hour lighting was observed to be very high, and a capital project recommendation was made to integrate lighting control with the building control system. Other important capital projects included replacement of VAV heating valves and $9^{\text {th }}$ floor return air ducting. Appendix A (Tables 20 and 21) provides a brief description of all the measures and implementation notes.

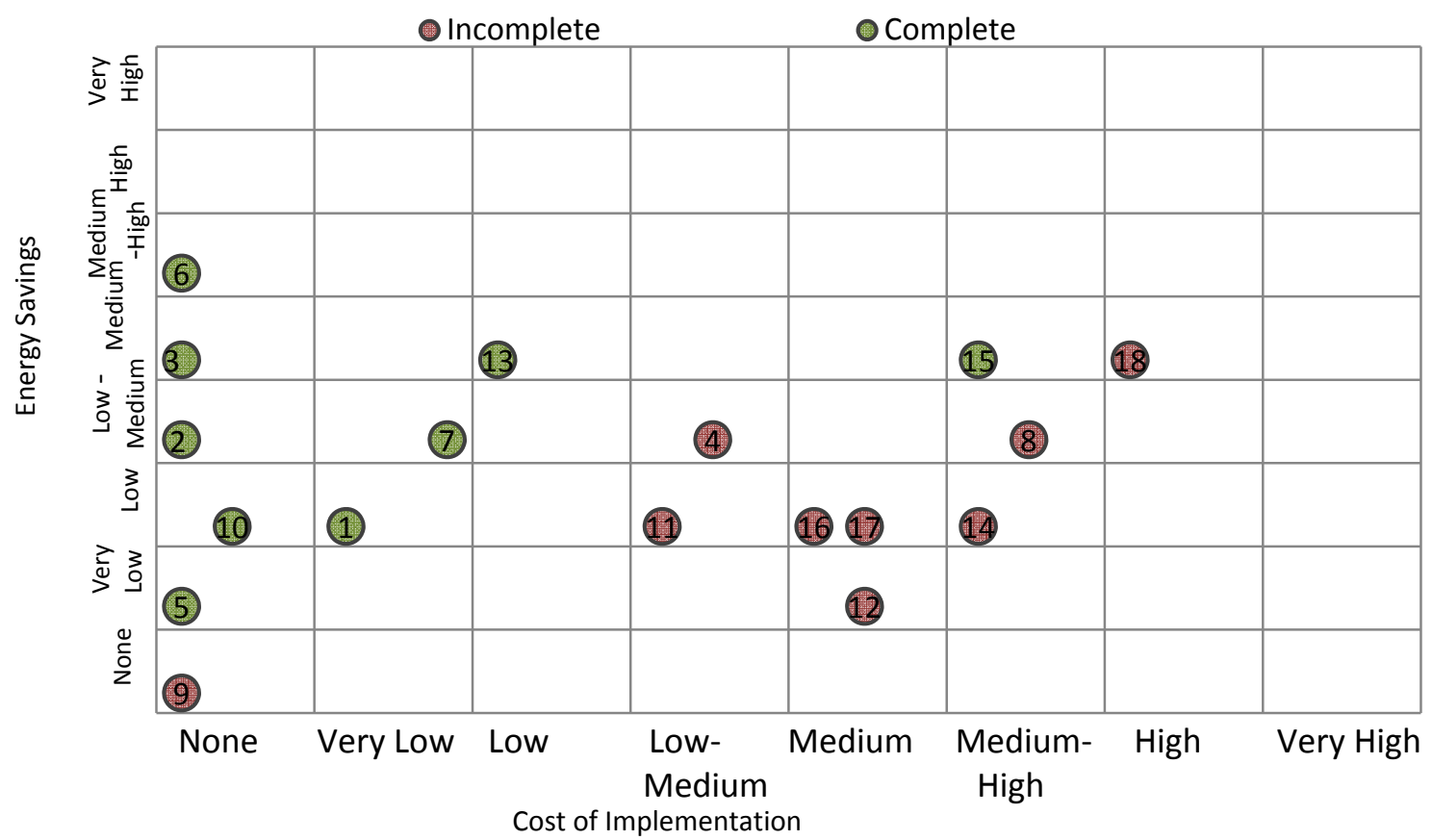

Figure 22: Implementation Status of E4 Recommendations at Zorinsky Federal Building

Figure 23 shows a history of energy consumption at the Zorinsky Federal Building. In FY09 and FY10, the Zorinsky Federal Building weather-corrected energy consumption was nearly the same, at about 100 kBtu/sf. Figure 24 shows that at the time of the E4 visit (December 2010), energy consumption in FY11 was on pace with energy consumption in FY09 and FY10. FY11, however, ended with 2.9\% lower energy consumption than FY10. Figure 24 shows that steam use has been decreasing steadily at the Zorinsky Federal Building since FY09, but chilled water increased substantially from FY09 to FY10, then dropped in FY11, and electricity consumption has been increasing modestly each year. Although several low-cost/no-cost measures were implemented, the Zorinsky Federal Building has a lot of potential for further improvements by modifying the control systems, which would require control contractor assistance to implement. There were no ARRA projects undertaken at this facility, but new capital 
projects are being considered to address the issues.

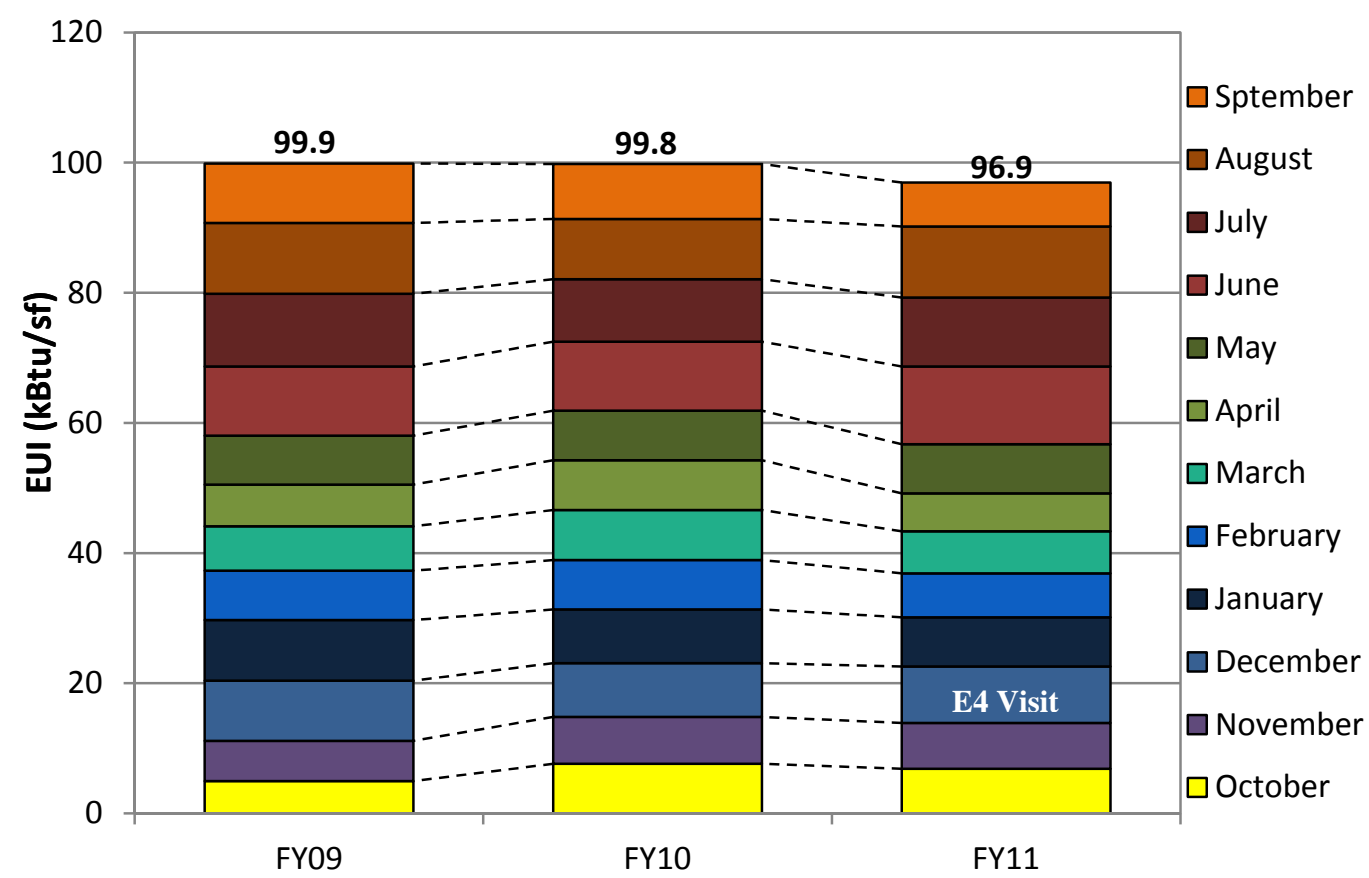

Figure 23: Annual and Monthly Weather-Corrected EUIs at Zorinsky Federal Building

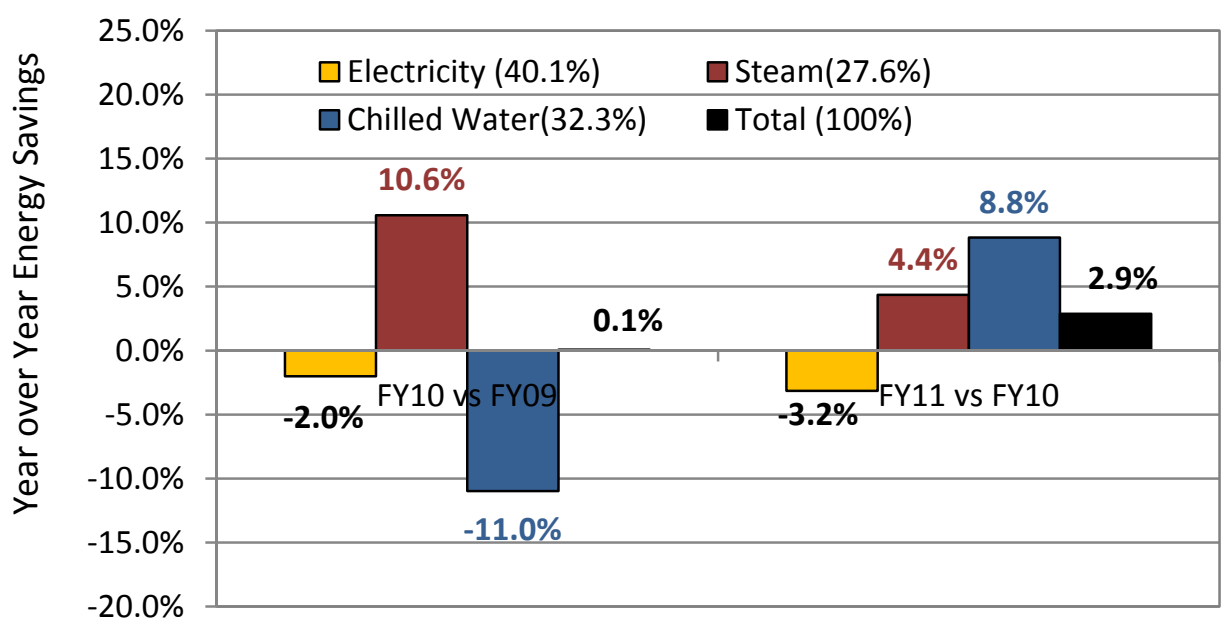

Figure 24: Weather-Corrected Energy Savings by Fuel Type at Zorinsky Federal Building 


\subsection{Facility Energy Use Summary}

This section summarizes each of the buildings' monthly utility billing data to determine the energy savings after E4 visits. These results are only weakly indicative of the efficacy of the E4 training and field audits because other factors, like occupancy changes and ARRA projects not related to the E4 visits, have also been taking place at the same time. Some sites are only now completing implementation of E4 measures, and the savings have not yet been reflected in the utility bills.

Table 1 shows the annual energy use intensities (EUI) for each of the buildings audited by E4 team (except Goodfellow Federal Center, which does not have sub-metered utility data for the building audited). In addition to the raw EUI numbers from utility billing data, weather-corrected EUIs are calculated for comparison without any bias. A normalization process is used to remove the effects of weather from this analysis by correlating building metered energy consumption with monthly observed weather data, then adjusting each month's energy consumption for typical weather. Weather-normalized data provides a better gauge for assessing performance and is more useful in predicting energy consumption. Appendix B describes the process of normalization.

It can be observed from Table 1 that the total EUI for all the eight buildings combined decreased by $6.3 \%$ in FY11 compared to FY10 based on utility billing data, which is equivalent to a $6.1 \%$ savings after correcting for weather. For most of the buildings, FY11 was the first full or partial fiscal year since the E4 visit took place, so it is the first time total annual savings can be calculated. For comparison, in FY10, although the total EUI increased 1.3\% compared to FY09, the actual energy use decreased by $2.0 \%$ after correcting for weather, when only two buildings had completed E4 audits.

Table 1: Annual Energy Use Intensities Across the E4 Building Portfolio

\begin{tabular}{|c|c|c|c|c|c|c|c|c|c|}
\hline \multicolumn{10}{|c|}{ Energy Use Intensities, EUI (kBtu/sf.) } \\
\hline & Neal Smith & Bannister & lowa City & RAY & Carlson & Whittaker & Zorinsky & Total & $\begin{array}{c}\text { Weighted } \\
\text { Savings }\end{array}$ \\
\hline FY07 & & & 74.5 & & & 71.2 & & & \\
\hline FY08 & 77.4 & 150.1 & 75.8 & 64.6 & 56.9 & 73.1 & & & \\
\hline FY09 & 76.0 & 125.2 & 68.4 & 62.6 & 55.8 & 77.0 & 98.8 & 90.6 & \\
\hline FY10 & 67.2 & 128.6 & 68.4 & 64.4 & 57.0 & 77.3 & 102.4 & 91.8 & $-1.3 \%$ \\
\hline FY11 & 64.0 & 116.7 & 69.6 & 64.1 & 53.4 & 70.6 & 98.5 & 86.0 & $6.3 \%$ \\
\hline \multicolumn{10}{|c|}{ Weather-Corrected EUI's (kBtu/sf.) } \\
\hline & Neal Smith & Bannister & lowa City & RAY & Carlson & Whittaker & Zorinsky & Total & $\begin{array}{c}\text { Weighted } \\
\text { Savings }\end{array}$ \\
\hline FY07 & & & 75.2 & & & 72.9 & & & \\
\hline FY08 & 76.8 & 151.2 & 74.0 & 65.6 & 56.9 & 73.9 & & & \\
\hline FY09 & 77.7 & 129.5 & 69.3 & 63.9 & 56.4 & 79.8 & 99.9 & 93.1 & \\
\hline FY10 & 67.8 & 127.1 & 68.2 & 65.1 & 57.1 & 76.5 & 99.8 & 91.2 & $2.0 \%$ \\
\hline FY11 & 64.8 & 115.7 & 68.7 & 64.6 & 53.7 & 70.2 & 96.9 & 85.6 & $6.1 \%$ \\
\hline
\end{tabular}


Another set of utility bill analyses was done to calculate the change in EUI using utility billing data for 12 months prior to E4 visit and current energy use in FY11. Table 2 provides a summary of this analysis, which shows that the Neal Smith Federal Building and the Bannister Federal Complex have demonstrated the highest percentage of energy savings, $17.3 \%$ and $11.0 \%$, respectively. These two buildings have had about 3 years since the $\mathrm{E} 4$ audits. Three other buildings have a moderate savings between $3.2 \%$ and $5.6 \%$, which is typically expected from an E4 effort in the first year or two after E4 audits. However, two facilities show increased energy use, which were observed to be a combination of ARRA projects and severe weather. Energy savings for the Goodfellow Federal Center could not be estimated because this building is not metered separately.

Table 2: Summary of Energy Savings Comparison

\begin{tabular}{|c|c|c|c|c|c|}
\hline \multirow{2}{*}{ Building Name } & \multirow{2}{*}{$\begin{array}{l}\text { Gross Floor } \\
\text { Area (sf) }\end{array}$} & \multirow{2}{*}{$\begin{array}{l}\text { E4 Field Visit } \\
\text { Date }\end{array}$} & \multicolumn{2}{|c|}{$\begin{array}{c}\text { Energy Use Intensity } \\
\text { (EUI) }\end{array}$} & \multirow{2}{*}{$\begin{array}{l}\text { Energy } \\
\text { Savings (\%) }\end{array}$} \\
\hline & & & Prior to E4 & Current & \\
\hline $\begin{array}{c}\text { Neal Smith Federal Building } \\
\text { Des Moines, IA }\end{array}$ & 390,000 & Nov. 2007 & 77.4 & 64.0 & 17.3 \\
\hline $\begin{array}{l}\text { Bannister Federal Complex } \\
\text { Kansas City, MO }\end{array}$ & $1,546,000$ & Apr. 2009 & 131.2 & 116.7 & 11.0 \\
\hline $\begin{array}{l}\text { lowa City Federal Building } \\
\text { lowa City, IA }\end{array}$ & 98,700 & Dec. 2009 & 69.0 & 69.6 & -0.8 \\
\hline $\begin{array}{l}\text { Robert A. Young Federal Building } \\
\text { Saint Louis, MO }\end{array}$ & $1,100,000$ & Feb. 2010 & 62.6 & 64.1 & -2.4 \\
\hline $\begin{array}{c}\text { Goodfellow Federal Center, Bldg. } 105 \\
\text { Saint Louis, MO }\end{array}$ & 225,000 & Mar. 2010 & - & - & - \\
\hline $\begin{array}{c}\text { Frank Carlson Federal Building \& } \\
\text { Courthouse } \\
\text { Topeka, KS }\end{array}$ & 232,500 & May 2010 & 55.9 & 53.4 & 4.5 \\
\hline $\begin{array}{c}\text { Charles Evans Whittaker U.S. Courthouse } \\
\text { Kansas City, MO }\end{array}$ & 753,500 & June 2010 & 74.8 & 70.6 & 5.6 \\
\hline $\begin{array}{c}\text { Zorinsky Federal Building } \\
\text { Omaha, NE }\end{array}$ & 415,500 & Dec. 2010 & 101.8 & 98.5 & 3.2 \\
\hline
\end{tabular}

A similar analysis of EnergyStar ratings of all the buildings were compared based on the utility data available for 12 months prior and after the E4 visits. Table 3 shows that the highest improvement in EnergyStar rating was realized at the Neal Smith Federal Building. Because the Bannister Federal Complex has many buildings, it was difficult to determine the EnergyStar rating. In general, all buildings improved their EnergyStar rating by 1 or 2 points, except for the Robert A Young Federal Building and Whittaker Courthouse, where there were negative or no change in the EnergyStar rating. In the RAY Federal Building, ARRA projects have caused disruption in the operation of mechanical systems, and this should be reevaluated next FY to determine the impact of E4. Although it is very difficult to attribute all the savings to E4 field training and recommendations, it is evident that Region 6 made significant progress toward reaching the goal of 30\% reduction by 2015. 
Table 3: EnergyStar Report Summary for all E4 Sub-metered Buildings

\begin{tabular}{|c|c|c|c|c|}
\hline & \multicolumn{2}{|c|}{ Previous EnergyStar Rating } & \multirow{2}{*}{$\begin{array}{l}\text { Current } \\
\text { EnergyStar } \\
\text { Rating }\end{array}$} & \multirow[b]{2}{*}{ Change } \\
\hline & $\begin{array}{l}\text { 12-month } \\
\text { End Date }\end{array}$ & Rating & & \\
\hline Neal Smith Federal Building & $10 / 30 / 2007$ & 79 & 90 & +11 \\
\hline Bannister Federal Complex & & -- & -- & -- \\
\hline Iowa City Federal Building & $12 / 31 / 2009$ & 81 & 83 & +2 \\
\hline Robert A Young Federal Building & $2 / 28 / 2010$ & 73 & 72 & -1 \\
\hline $\begin{array}{l}\text { Frank Carlson Federal Building and } \\
\text { Courthouse }\end{array}$ & $5 / 31 / 2010$ & 84 & 89 & +5 \\
\hline $\begin{array}{l}\text { Charles Evans Whittaker U.S. } \\
\text { Courthouse }\end{array}$ & $6 / 30 / 2010$ & 75 & 77 & +2 \\
\hline Zorinsky Federal Building & $12 / 31 / 2010$ & 77 & 78 & +1 \\
\hline
\end{tabular}




\subsection{E4 Follow-up Visit Summary}

Based on the E4 follow-up interviews and analysis of the energy impact, two buildings were selected for further field evaluation to review the implementation and provide assistance with control-system-related E4 recommendations that have not yet been implemented. In consultation with the regional staff, Bannister Federal Complex and Frank Carlson Federal Building and Courthouse were identified as two facilities that would benefit from this effort. These two facilities had a large number of control-systemrelated measures that were either not implemented or not effective. This field visit was combined with a parallel effort undertaken by GSA Region 6 staff to develop a targeted-E4 program that is designed to help facility managers and O\&M contractors with a resource to implement control system changes and monitor the impact of these changes periodically as part of the routine maintenance activities rather than retaining control system contractors for specific projects.

\subsection{Bannister Federal Complex}

The Bannister Federal Complex was visited during December 2011. A field inspection of the E4 recommendations and their implementation was reviewed. Figure 25 shows one of the low-cost/no-cost measures implemented to avoid simultaneous heating and cooling by insulating steam pipes in airhandling units that were warm even when the system was only providing cooling.
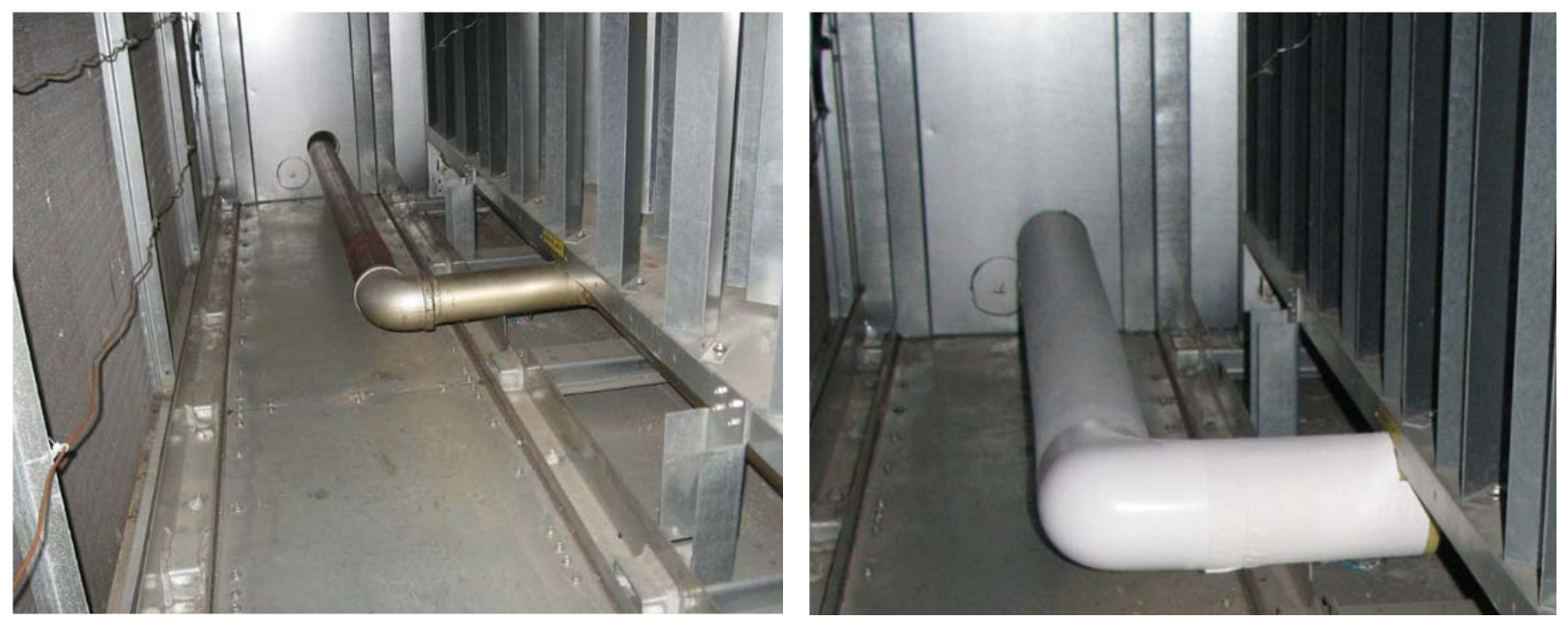

Figure 25: Steam Pipes Inside AHUs

(Left: Uninsulated prior to E4 visit; Right: Insulated, as observed during follow-up visit)

Overall, the E4 team observed that several of the high priority recommendations were implemented by Bannister staff, which included:

- Insulation of exposed steam/condensate lines

- Avoiding simultaneous heating and cooling caused by uinsulated steam pipes in preheat coils

- Revision to economizer control strategies and replacement of humidity sensor

- Occupancy sensors in most corridors and restrooms

- CRAC units and computer room chillers reprogrammed and monitored to avoid over reheating.

- Updates to air handler in mechanical room 4B that could not provide cooling because of uninsulated steam pipe in the return-air stream 
Although Bannister Federal Complex staff have implemented several of the low-cost/no-cost measures identified during the initial visit, the follow-up visit identified many control system changes that have not been implemented because of limited resources and the uncertainty surrounding the facility. The E4 team reviewed the original list of recommendations and based on the recent changes that have occurred at the facility, developed a consolidated new list of 15 control-system-related opportunities, as listed below:

- Add schedules to AHUs to shut down at night

- Reduce existing schedules by 1 hour (start 30 min. late, shutdown 30 min. early)

- Control code changes for shut-off

- Revise economizer control strategy based on dry-bulb temperature

- Add static pressure reset

- Add supply air temperature reset

- Add/adjust AHU schedules to fan houses and stagger the startup time

- Revise the control strategy for VAV boxes in vacant spaces

- Revise damper control strategy to minimize outdoor-air intake during unoccupied hours

- Change control code for return tans

- Scheduling of restroom exhaust fans

- Fix steam leak in Fan House 3 heating coil

- Add demand control ventilation strategies using existing $\mathrm{CO}_{2}$ sensors

- Close valves and dampers when fans shut off

- Add BAS code for energy measurements/trending.

Some of the above listed measures were implemented during the December 2011 visit. This includes static-pressure reset and supply-air temperature reset on the air handlers in Building 2, as well as programming of holidays in the building automation system. Further work is in progress to implement the remaining items by training the O\&M staff and with subsequent reviews during future visits as part of the on-going targeted-E4 effort.

\subsection{Frank Carlson Federal Building and Courthouse}

The Frank Carlson Federal Building and Courthouse was visited immediately following the Bannister Federal Complex site visit. The initial E4 recommendations included 16 low-cost/no-cost opportunities and 4 capital projects. Although a few of the recommendations were addressed as a result of other projects, several of the original recommendations related to control system changes were not implemented (except for lighting schedules). The E4 team prepared a new list of 15 measures focused on advanced control system improvements, listed in Table 4. 
Table 4: Targeted-E4 Recommendations and Expected Savings

\begin{tabular}{|l|l|c|}
\hline No. & \multicolumn{1}{|c|}{ Description } & $\begin{array}{c}\text { Expected } \\
\text { Savings }\end{array}$ \\
\hline 1 & Lighting schedules & $1.0 \%$ \\
\hline 2 & Static-pressure reset & $1.0 \%$ \\
\hline 3 & Supply-air temperature reset & $0.9 \%$ \\
\hline 4 & Economizer maximum outdoor air flow rate & None \\
\hline 5 & Chilled water differential pressure reset & 0.3 to $2.5 \%$ \\
\hline 6 & Chilled water temperature reset & $0.8 \%$ \\
\hline 7 & Heating nighttime setback & $5.9 \%$ \\
\hline 8 & Optimal start & TBD \\
\hline 9 & Staggered AHU start-up & None \\
\hline 10 & AHU minimum damper position & $0.1 \%$ \\
\hline 11 & Pneumatic device compressed air set point & None \\
\hline 12 & Condensate drains & None \\
\hline 13 & Control of solar water heating system & TBD \\
\hline 14 & Miscellaneous loads (e.g., snow melt system) & TBD \\
\hline 15 & Monitoring and diagnostics improvements & None \\
\hline
\end{tabular}

An energy model of the Carlson Federal Building and Courthouse has been recently developed by PNNL under a separate effort for GSA Region 6. This model was used to calculate potential energy savings resulting from the proposed control system changes. Table 4 includes the calculated savings for seven measures implemented during the follow-up visit. The Carlson Federal Building and Courthouse has an advanced metering system, and GSA staff can provide interval data (15 $\mathrm{min}$ ) of electric demand and energy use. This data has been very effectively used to verify the impact of control system changes made during the months of January through March 2012.

Since the initial targeted E4 visit in December, 2 months of energy bill data has been received (January and February 2012). Compared to the three previous Januaries, the Carlson Federal Building and Courthouse used $17.8 \%$ less energy. Although this could be largely caused by mild weather, the weathercorrected savings were calculated and estimated to be $6.6 \%$, as shown in Table 5. Based on current estimates using the EnergyPlus model, the Carlson Federal Building and Courthouse is expected to save $12.5 \%$ annual energy by the end of FY12, largely because of control system improvements made through the targeted-E4 effort.

Table 5: Electricity Bill Summary (post- Targeted-E4 Visits)

\begin{tabular}{|c|c|c|c|c|}
\hline Month & $\begin{array}{c}\text { FY10 \& FY11 } \\
\text { Average }\end{array}$ & FY12 & FY12 Change & $\begin{array}{c}\text { Weather-Corrected } \\
\text { FY12 Change }\end{array}$ \\
\hline December & 432,000 & 336,600 & $-22.1 \%$ & $-15.8 \%$ \\
\hline January & 378,800 & 311,395 & $-17.8 \%$ & $-\mathbf{6 . 6 \%}$ \\
\hline February & 319,200 & 244,800 & $-23.3 \%$ & $-12.8 \%$ \\
\hline
\end{tabular}

The follow-up visits to both the Bannister Federal Complex and the Frank Carlson Federal Building and Courthouse underscore the need for working with O\&M staff to implement control system changes, which are critical to realizing the energy savings. 


\subsection{Conclusions}

Energy consumption across the portfolio of buildings that have undergone E4 assessments (field training and field audits) is trending towards measurable energy savings as of FY11. For most of the sites, it has been about 1 to $1 \frac{1 / 2}{2}$ years since the E4 visit. These sites have realized a 6.3\% reduction in energy consumption during the past year, which represents an energy cost savings of $\$ 260,000$ relative to what the sites would have been billed at FY10 levels of consumption. It is difficult to determine if this savings is a direct result of E4 efforts because many sites were influenced not only by E4 field audits, but also by other retro-commissioning studies. Another factor influencing how many of the E4 recommendations were implemented at each site was dependent on the ARRA funding for capital projects. ARRA projects often provided the funding for building staff to act on high priority E4 recommendations.

Some of the significant savings that have materialized so far has been for the two sites with the earliest E4 visits (Neal Smith Federal Building and Bannister Federal Complex). This perhaps suggests that a 2 to 3 year time frame after the E4 visits is the best time to fully assess the impact of E4 measures implemented in these buildings. The Robert A Young Federal Building also served to highlight this point with the longer time required for implementation. Through the end of FY11, there is no observable savings at that site; however, the site staff indicated that there were a wide range of E4 measures that were being implemented in late FY11 and early FY12, and consequently savings have not been reflected in the utility bills through September 2011. Some of these capital projects (e.g., replacing windows) actually caused temporary increases in energy use during the implementation phase. Considering these factors, most sites are expected to show higher savings in FY12 than in FY11.

The most important lesson for the E4 team in this process is that often there are significant barriers to implementing low-cost/no-cost measures. Based on input received from GSA facility managers and O\&M staff, there is a clear pattern, wherein the O\&M staff do not have the expertise to program/ implement some of the advanced control measures in their building automation systems. The conventional alternative is to hire a building controls contractor to visit the site and implement the changes. The cost to hire controls contractors is high and makes the "low-cost/no-cost" measures economically infeasible. In general, cost constraints were cited most often as the reason for not implementing E4 measures. There is a definite need for periodic building retuning reviews and controls changes that do not require control systems contractors. The E4 team has begun to address this need in its targeted-E4 effort. Using this new approach, instead of only identifying problems/opportunities and making recommendations, PNNL is bringing controls experts to these sites who can work with the O\&M staff to directly implement advanced controls measures and train O\&M staff in more of a hands-on way to manage schedules and building energy systems with energy conservation in mind. The follow-up visit and control system changes made at Bannister Federal Complex and Frank Carlson Federal Building and Courthouse as part of the targeted-E4 project have so far proven to be very effective and are expected to demonstrate significant energy savings in FY12.

An additional benefit of E4 field audits has been the facilitation of dialogue between the O\&M contractors and GSA facilities management staff. In general, they are focused on tenant satisfaction and responding to owner/client needs rather than discussing issues related to energy efficiency or operational improvements. By bringing them together and helping them recognize the value of BAS trend data reviews and its potential to address customer complaints, a number of conversations have taken place between GSA and the O\&M contractors around how to balance energy-efficiency considerations with tenant satisfaction. 
In summary, the E4 field audits have tremendously helped the region with identifying and implementing energy-saving measures in these eight facilities, resulting in approximately 6\% annual energy savings and improving EnergyStar rating by about 2 or 3 points in FY11 for most facilities. However, the effectiveness of implementation can be better realized with targeted-E4 efforts, as evidenced from the follow-up field visits. 


\section{APPENDIX A}

\section{E4 Recommendations}




\section{Appendix A: E4 Recommendations}

Table 6: Measures Fully or Partly Implemented - Neal Smith Federal Building

\begin{tabular}{|c|c|c|}
\hline \# & Recommended Measure & Implementation Details / Notes \\
\hline 1 & $\begin{array}{l}\text { Revise all air-handler schedules to start at 5:00 a.m. and } \\
\text { turn off at 5:30 p.m. Add a schedule to Metasys to lower } \\
\text { the static pressure set point to } 1.25 \text { in. after 4:00 p.m. } \\
\text { Install an optimal start program to automatically start } \\
\text { supply fans earlier, when the outside temperatures are } \\
\text { above or below design limits }\end{array}$ & $\begin{array}{l}\text { Schedule revisions were made in 2008. Currently all air } \\
\text { handlers are replaced and undergoing commissioning, which } \\
\text { will address all the recommendations }\end{array}$ \\
\hline 2 & $\begin{array}{l}\text { Synchronize VA-1 and VA-2 fan operation with AHU-E } \\
\text { and AHU-F operation }\end{array}$ & Completed in 2008 \\
\hline 4 & $\begin{array}{l}\text { Install the optimal start program to schedule the chiller } \\
\text { and boiler startup times }\end{array}$ & Being implemented as part of the on-going ARRA projects \\
\hline 5 & $\begin{array}{l}\text { Redesign the P-trap on AHU-A and AHU-B to avoid air } \\
\text { entering from the drain }\end{array}$ & $\begin{array}{l}\text { Completed in Dec. 2009, and now all the air handlers are } \\
\text { replaced }\end{array}$ \\
\hline 6 & $\begin{array}{l}\text { Inspect supply, return and relief dampers in all air } \\
\text { handlers for proper operation. }\end{array}$ & Completed in 2008 \\
\hline 7 & $\begin{array}{l}\text { Evaluate location of return air and mixed air temperature } \\
\text { sensors and modify for proper operation }\end{array}$ & Completed in 2008 \\
\hline 8 & $\begin{array}{l}\text { Identify and fix the cause of apparent static pressure mis- } \\
\text { readings }\end{array}$ & Completed in 2008 \\
\hline 9 & Repair refrigerant leak in Chiller \#2 & Completed in 2008; new chillers installed in 2009 \\
\hline 10 & $\begin{array}{l}\text { Install missing insulation on steam traps and refrigerant } \\
\text { piping to one of the Libert chiller condensing units }\end{array}$ & Complete in 2008 \\
\hline 11 & Install seals on double doors at loading dock & Completed in 2008 \\
\hline 12 & $\begin{array}{l}\text { Repair leaking three-way water valve and clean coil of } \\
\text { Libert chiller serving VA }\end{array}$ & Completed in 2008 \\
\hline 13 & Seal fixed opening in elevator room open to outdoor air & Completed in 2008 \\
\hline 15 & $\begin{array}{l}\text { De-lamp ceiling fixtures in perimeter zone offices and } \\
\text { add task lighting as needed }\end{array}$ & $\begin{array}{l}\text { De-lamping done in 2008; new Lutron lighting system } \\
\text { installed as part of ARRA projects }\end{array}$ \\
\hline 16 & $\begin{array}{l}\text { Replace all T-8 32W fluorescent lamps with high - } \\
\text { efficiency 25W T-8 lamps }\end{array}$ & Replaced 1100 lamps in April-September 2008 \\
\hline 17 & Replace the filtrine cooling unit providing potable water & The unit was decommissioned and replaced \\
\hline 18 & $\begin{array}{l}\text { Replace the second chiller with a small chiller that can } \\
\text { run at full capacity when cooling demand is low. } \\
\text { Schedule chillers with a lead/lag program. Add VFDs } \\
\text { for the cooling tower and fans. }\end{array}$ & $\begin{array}{l}\text { New chiller plant with four } 250 \text {-ton chillers replacing the two } \\
\text { older } 750 \text {-ton chillers in } 2009\end{array}$ \\
\hline 19 & $\begin{array}{l}\text { Enable economizing for AHU-H and use economizer } \\
\text { whenever outdoor air can cool the building }\end{array}$ & $\begin{array}{l}\text { Completed in 2008, new air handlers installed as part of on- } \\
\text { going ARRA projects with heat recovery wheel }\end{array}$ \\
\hline 20 & Add VFDs to all six zone pumps serving the induct boxes & ARRA projects removed the induction boxes \\
\hline 21 & Install occupancy sensors for all restroom lights & Installed 45 sensors during Sept.-Oct. 2008 \\
\hline 22 & Install wireless thermostats for zone control & ARRA project implemented building wide in 2010-2011 \\
\hline
\end{tabular}

Table 7: Measures Not Implemented - Neal Smith Federal Building

\begin{tabular}{|c|l|l|}
\hline$\#$ & \multicolumn{1}{|c|}{ Recommended Measure } & \multicolumn{1}{|c|}{ Implementation Details / Notes } \\
\hline 3 & $\begin{array}{l}\text { Raise the chilled water temperature to } 48^{\circ} \mathrm{F} \text { or } 49^{\circ} \mathrm{F} \\
\text { depending on the needs of the building and loads on the } \\
\text { chiller (Chilled water reset) }\end{array}$ & $\begin{array}{l}\text { Originally implemented, but due to humidity issues during } \\
\text { May-Aug. 2008, the measure was reverted }\end{array}$ \\
\hline 14 & $\begin{array}{l}\text { Install permanent shading and sealing of windows in the } \\
10^{\text {th }} \text { floor data center }\end{array}$ & $\begin{array}{l}\text { No permanent shading, but new window shades have been } \\
\text { installed }\end{array}$ \\
\hline
\end{tabular}


Table 8: Measures Fully or Partly Implemented - Bannister Federal Complex

\begin{tabular}{|c|c|c|}
\hline \# & Recommended Measure & Implementation Details / Notes \\
\hline 1 & $\begin{array}{l}\text { Close rollup doors and exit doors when not in use to } \\
\text { maintain envelope security }\end{array}$ & $\begin{array}{l}\text { A procedural change was implemented at the site. Also, some } \\
\text { interior doors that previously had a single set of doors now } \\
\text { have a double set of doors with an air lock }\end{array}$ \\
\hline 2 & $\begin{array}{l}\text { Selectively de-lamp brightly-lit hallways and install } \\
\text { daylight sensors }\end{array}$ & $\begin{array}{l}\text { All of the hallways in Buildings } 1 \text { and } 2 \text { are now controlled } \\
\text { via occupancy sensors that turn off } 80 \% \text { of the lights after } 15 \\
\text { minutes if no one walks by. This is effective in limiting light } \\
\text { in low-occupancy areas and keeping the lights to a minimum } \\
\text { overnight. About } 5-10 \% \text { of office spaces in Building } 2 \text { have } \\
\text { de-lamped by removing } 1 / 2 \text { of lamps in overhead fixtures. }\end{array}$ \\
\hline 3 & $\begin{array}{l}\text { Disable steam to SBC } 22.5 \text { when HVAC unit has been } \\
\text { turned off }\end{array}$ & $\begin{array}{l}\text { This space is now unoccupied. The space is monitored and } \\
\text { the valves are turned off }\end{array}$ \\
\hline 4 & $\begin{array}{l}\text { Fix air handler serving fitness center (PB8-2) to enable } \\
\text { economizing (fix failed ductwork isolation dampers, etc.) }\end{array}$ & $\begin{array}{l}\text { This has been fixed. This air handler is now on the Metasys } \\
\text { system. Economizers are working. }\end{array}$ \\
\hline 5 & $\begin{array}{l}\text { Add missing pipe insulation on steam/condensate lines in } \\
\text { loading docks, hallways, inside supply fan plenums and } \\
\text { mechanical rooms }\end{array}$ & $\begin{array}{l}\text { This was done on a small scale for two of the areas } \\
\text { highlighted in the report: inside the air handlers and above the } \\
\text { ceiling of the offices. This was completed for } \$ 8,200 \text {. Only } \\
\text { small areas were affected, but insulating above the office has } \\
\text { greatly improved control and tenant comfort there. An } \\
\text { estimate was provided for the full re-insulation project } \\
(\$ 147,000) \text {. It was deemed too expensive. }\end{array}$ \\
\hline 6 & $\begin{array}{l}\text { The HVAC unit (in 4B machine room, SBQ-16.5) } \\
\text { serving the basement GSA South Field } \\
\text { Office/USDA/All-Star offices and adjoining office } \\
\text { spaces should be converted from the DX system ( } 30 \text { ton) } \\
\text { to chilled water cooling coil. The outside air ducts with } \\
\text { manual dampers should be converted to automatic } \\
\text { dampers to allow the system to economize. }\end{array}$ & $\begin{array}{l}\text { O\&M staff effectively enabled economizing on this unit. This } \\
\text { action eliminated the need to upgrade the coils on this unit } \\
\text { (staff had been considering adding a small stand-alone chiller } \\
\text { for } \$ 51,000 \text { ). }\end{array}$ \\
\hline 7 & $\begin{array}{l}\text { When building becomes “smoke-free”, permanently shut } \\
\text { down exhaust fans serving “smoking” spaces }\end{array}$ & These spaces have been recently decommissioned \\
\hline 8 & Disable under floor AC unit electric heaters if not needed & Completed. \\
\hline 9 & $\begin{array}{l}\text { Replace existing outdoor air humidity sensors for } \\
\text { economizer and place in better locations (i.e., away from } \\
\text { steam outlets. Use redundant sensors and choose lowest } \\
\text { reading for economizing. }\end{array}$ & $\begin{array}{l}\text { The humidity sensor was moved to the edge of the tower } \\
\text { away from the steam outlet pipe. This humidity sensor was } \\
\text { previously always reading } 100 \% \text { relative humidity (RH) and } \\
\text { preventing economizing from taking place - building wide. }\end{array}$ \\
\hline 10 & $\begin{array}{l}\text { Raise economizer lockout temperature from } \\
55^{\circ} \mathrm{F} \text { to } 65^{\circ} \mathrm{F}\end{array}$ & $\begin{array}{l}\text { On some of the units, the lockout was moved to } 65^{\circ} \mathrm{F} \text {, but it } \\
\text { has been moved back for some because of customer } \\
\text { complaints (humidity). There appears to still be the } \\
\text { opportunity to implement this lockout during shoulder months } \\
\text { when the humidity is lower }\end{array}$ \\
\hline 11 & $\begin{array}{l}\text { Lower preheat outdoor air enable down to } 35^{\circ} \mathrm{F} \text {. Any } \\
\text { other control strategies implemented for preheat } \\
\text { controls? }\end{array}$ & $\begin{array}{l}\text { This has been done and has helped to control the temperatures } \\
\text { in the tenant spaces }\end{array}$ \\
\hline 12 & $\begin{array}{l}\text { Review Lobby } 2 \text { AHU } 16 \text { East/West to ensure that the } \\
\text { chilled water bypass control valve is working properly. } \\
\text { Two fans were observed to have the bypass valve open } \\
100 \% \text { during mechanical cooling. }\end{array}$ & This was reviewed and is working properly \\
\hline 13 & $\begin{array}{l}\text { Reduce the static pressure set point by at least } 50 \% \text { after } \\
6 \text { p.m. weeknights and all day on weekends }\end{array}$ & $\begin{array}{l}\text { This was initiated during the original E4 visit. At the time of } \\
\text { the survey, static pressure set points were scheduled to drop } \\
\text { for overtime utilities. A full static pressure reset has been } \\
\text { implemented for Building } 2 \text { as part of PNNL's targeted-E4 } \\
\text { site visit in December } 2011\end{array}$ \\
\hline
\end{tabular}


Table 9: Measures Not Implemented - Bannister Federal Complex

\begin{tabular}{|c|c|c|}
\hline \# & Recommended Measure & Implementation Details / Notes \\
\hline 14 & $\begin{array}{l}\text { Add rollup door sensor monitoring to allow disabling } \\
\text { area heating/HVAC systems serving rollup door areas } \\
\text { when they are open }>15 \text { minutes }\end{array}$ & Not Implemented (cost) \\
\hline 15 & $\begin{array}{l}\text { Replace standalone time clocks, standalone legacy DDC } \\
\text { controls and older pneumatic controls with Metasys DDC } \\
\text { controls. Eventually add } \\
\text { heating/cooling/economizer/static controls }\end{array}$ & Not implemented (cost) \\
\hline 16 & $\begin{array}{l}\text { Add lighting controls for loading dock and atrium } \\
\text { lighting such that when outside light levels are }>200 \mathrm{fc} \text {, } \\
\text { the interior lighting is reduced }\end{array}$ & Not implemented \\
\hline 17 & $\begin{array}{l}\text { Add VFDs to motor-driven loads not already controlled } \\
\text { by VFDs (fans and pumps), and remove inlet vanes } \\
\text { (fans) after installation }\end{array}$ & Not upgrades to VFDs \\
\hline 18 & $\begin{array}{l}\text { Add controls for selected exhaust fans to start when the } \\
\text { space overheats and stop when the temperature is at } \\
\text { acceptable maximum levels }\end{array}$ & Not implemented \\
\hline 19 & Add schedules for cabinet unit heaters in the lobby fans & No schedules added \\
\hline 20 & $\begin{array}{l}\text { Add individual schedules to run auditorium HVAC: start } \\
6 \text { a.m., stop } 7 \text { a.m., start } 9 \text { a.m., stop } 10 \text { a.m., start noon, } \\
\text { stop } 1 \text { p.m., start } 3 \text { p.m., stop } 4 \text { p.m. (Monday -Friday). }\end{array}$ & $\begin{array}{l}\text { The building still works off the GSA schedule, same as } 2008 \text {. } \\
\text { In general, the HVAC for the auditorium only operates when } \\
\text { the gym is occupied. }\end{array}$ \\
\hline 21 & $\begin{array}{l}\text { Add economizers to basement level supply fans BOE-24 } \\
\text { and BOE-26 }\end{array}$ & Economizers have not been added \\
\hline 22 & $\begin{array}{l}\text { Provide automated economizing to Building } 1 \text { sub- } \\
\text { basement mall level by adding damper actuators to } \\
\text { outside and return dampers }\end{array}$ & Not implemented \\
\hline 23 & $\begin{array}{l}\text { Add Metasys start/stop controls and VFDs to the two 20- } \\
\text { hp pumps in Buildings } 1 \text { and } 2\end{array}$ & Not implemented \\
\hline 24 & $\begin{array}{l}\text { Chilled water reset - reset from } 42^{\circ} \mathrm{F} @ 80^{\circ} \mathrm{F} \text { outdoor air } \\
\text { temp up to } 46^{\circ} \mathrm{F} @ 60^{\circ} \mathrm{F} \text { outside-air temp }\end{array}$ & No chilled water reset implemented at the time of the survey \\
\hline 25 & $\begin{array}{l}\text { Replace steam heating system with electric heating } \\
\text { system or gas boilers to allow for summer steam } \\
\text { shutdown }\end{array}$ & $\begin{array}{l}\text { This is a clear goal at the site. There are only a few minor } \\
\text { steam loads in the summer and the site believes that it can } \\
\text { shut down the steam in the summer if it can replace these } \\
\text { loads with independent boilers or with electrical end uses. } \\
\text { This would yield substantial savings. No action so far. }\end{array}$ \\
\hline 26 & $\begin{array}{l}\text { Extend Building 2, Lobby 3, AHU-26/SF-3 ductwork to } \\
\text { basement systems currently being served by (2) 30-ton } \\
\text { chilled water systems (A-23). Evaluate if VAV boxes } \\
\text { should be added or zoning left as is. Consider upgrading } \\
\text { to Metasys control }\end{array}$ & Not implemented \\
\hline 27 & $\begin{array}{l}\text { Add Metasys control to the hot water steam heat } \\
\text { exchanger and the chilled water heat exchanger to obtain } \\
\text { desired tempered water temperatures for thee } \\
\text { heating/cooling seasons, respectively. Use hot water } \\
\text { temperature reset }\end{array}$ & Not possible to implement. Water is from outside source. \\
\hline 28 & $\begin{array}{l}\text { Use return air } \mathrm{CO}_{2} \text { sensor (does this already exist) to } \\
\text { control minimum OA damper (no OA below } 800 \mathrm{ppm} \rightarrow \\
\text { full OA at } 1000 \mathrm{ppm} \text { ) }\end{array}$ & $\begin{array}{l}\left.\text { There are } \mathrm{CO}_{2} \text { sensors installed in Building } 2 \text { ( } 300,000 \mathrm{sf}\right) \text {. } \\
\text { They can be used for demand control ventilation, but are not } \\
\text { currently being used. }\end{array}$ \\
\hline 29 & Add discharge air reset schedule (from $55^{\circ} \mathrm{F}$ up to $65^{\circ} \mathrm{F}$ ) & $\begin{array}{l}\text { This was not done by the staff. E4 team implemented this } \\
\text { measure during the targeted-E4 visit in December } 2011 \text {. The } \\
\text { current measure linearly adjusts the discharge temperature set } \\
\text { point between } 55 \text { and } 65^{\circ} \mathrm{F} \text { based on return-air temperature. } \\
\text { This was only an option for Building } 2 \text {. }\end{array}$ \\
\hline
\end{tabular}


Table 10: Measures Fully or Partly Implemented - Iowa City Federal Building

\begin{tabular}{|c|c|c|}
\hline \# & Recommended Measure & Implementation Details / Notes \\
\hline 1 & Replace/add weather stripping to exterior doors & Completed in 2010 as part of front entry project \\
\hline 2 & $\begin{array}{l}\text { Relocate daylight sensor for exterior lights to the south or } \\
\text { east of the building }\end{array}$ & Completed in 2010 as part of front entry project \\
\hline 5 & $\begin{array}{l}\text { Add schedules to exhaust fans EF-4 and EF-5 to ensure } \\
\text { they are only run as needed. Recommended 6:00 a.m. to } \\
\text { 6:00 p.m. Install necessary hardware to put EF-2 and } \\
\text { EF-3 on Metasys control, then apply schedule to them. }\end{array}$ & Completed in 2010 \\
\hline 6 & $\begin{array}{l}\text { Retune and recalibrate the air handlers periodically to } \\
\text { assure that the heating/cooling valves are automatically } \\
\text { opening and closing as needed by the control system }\end{array}$ & $\begin{array}{l}\text { Partly completed in } 2011 \text { as part of the ARRA projects and } \\
\text { currently being commissioned }\end{array}$ \\
\hline 8 & $\begin{array}{l}\text { Tighten schedules in AC-1, AC-2, AC-3, AC-5, AC-6. } \\
\text { Recommended start 6:00 a.m. - stop 6:00 p.m. }\end{array}$ & Completed in 2010 \\
\hline 9 & $\begin{array}{l}\text { Periodically review economizer dampers for proper } \\
\text { operation (tight shut off, correct opening) }\end{array}$ & Completed in 2010 \\
\hline 10 & $\begin{array}{l}\text { For AC-2,3,4,6 - Revise the control strategy such that } \\
\text { when the fan shuts down, the heating valve will only fail } \\
\text { wide open if the outside temperature is less than } 35^{\circ} \mathrm{F} \\
\text { and the mixed-air temperature is less than } 45^{\circ} \mathrm{F}\end{array}$ & $\begin{array}{l}\text { AC-2 and AC-6 are complete; AC-3 and AC- } 4 \text { are pending } \\
\text { ARRA project completion and commissioning }\end{array}$ \\
\hline 11 & $\begin{array}{l}\text { Add VFDs to both the supply and return fans and lock } \\
\text { the inlet vanes open }\end{array}$ & ARRA project addressed this in 2010-2011 \\
\hline 12 & $\begin{array}{l}\text { Add Metasys schedule for AC-5; ensure that the fan is } \\
\text { shut off at least } 4 \text { hours per day }\end{array}$ & Completed in 2010 \\
\hline 13 & AC-6 schedule and control strategy revisions & Addressed as described in item 10 \\
\hline 14 & $\begin{array}{l}\text { Chilled water temperature reset based on outdoor-air } \\
\text { temperatures, adjust temperature set point for chilled } \\
\text { water }-50^{\circ} \mathrm{F} \text { for cool outdoor-air conditions down to } \\
44^{\circ} \mathrm{F} \text { for hot conditions }\end{array}$ & Completed in 2010 \\
\hline 15 & $\begin{array}{l}\text { Reduce cycling of chillers by either starting them later or } \\
\text { by implementing chilled water temperature reset }\end{array}$ & Completed in 2010 \\
\hline 16 & $\begin{array}{l}\text { Repair zone pumps that are out of service for more } \\
\text { flexibility in facilities operation; Fix the leaking steam } \\
\text { control valve on steam hot-water converter; Reduce } \\
\text { excess heat in garage, post office floor and other } \\
\text { floor/wall/ceiling spaces }\end{array}$ & ARRA projects completed replacing these in 2010-2011 \\
\hline 17 & $\begin{array}{l}\text { Reduce the number of mail room lights and install more } \\
\text { task lighting }\end{array}$ & Completed in 2010 \\
\hline 18 & Post office lobby lighting controls with daylight sensors & Completed as part of front lobby renovation project in 2010 \\
\hline 19 & $\begin{array}{l}\text { AC-3 and AC-4: Replace the static pressure controls and } \\
\text { reprogram }\end{array}$ & ARRA project replaced and completed this in 2010-2011 \\
\hline 21 & $\begin{array}{l}\text { Replace steam boiler with hot water heating (preferably } \\
\text { condensing) boiler }\end{array}$ & Replaced in 2010-2011 with ARRA projects \\
\hline
\end{tabular}


Table 11: Measures Not Implemented - Iowa City Federal Building

\begin{tabular}{|l|l|l|}
\hline$\#$ & \multicolumn{1}{|c|}{ Recommended Measure } & \multicolumn{1}{|c|}{ Implementation Details / Notes } \\
\hline 3 & De-lamp on $2^{\text {nd }}$ floor corridor to reduce light levels & $\begin{array}{l}\text { Attempted, but could not be implemented because removing a } \\
\text { bulb causes the fixture not to work }\end{array}$ \\
\hline 4 & $\begin{array}{l}\text { Consider shutting off heat to the loading dock mezzanine } \\
\text { if there is no valid reason to heat it }\end{array}$ & $\begin{array}{l}\text { Unit heater has thermostat, but the issues is unclear and needs } \\
\text { further review }\end{array}$ \\
\hline 7 & Re-balance and re-calibrate VAV boxes & Not implemented (lack of funding) \\
\hline 20 & Install VFDs on chillers and cooling tower fans & Lack of funding \\
\hline 22 & Install photovoltaics on existing solar hot water racks & Uneconomical and need to validate project cost \\
\hline
\end{tabular}


Table 12: Measures Fully or Partly Implemented - Robert A Young Federal Building

\begin{tabular}{|c|c|c|}
\hline \# & Recommended Measure & Implementation Details / Notes \\
\hline 1 & $\begin{array}{l}\text { Replace/add weather stripping to exterior and data center } \\
\text { doors }\end{array}$ & $\begin{array}{l}\text { This is being performed as part of an ARRA project envelope } \\
\text { upgrade. So far the } 11^{\text {th }} \text { floor doors have been weather- } \\
\text { stripped, and the main floor doors should be completed by the } \\
\text { end of the project }\end{array}$ \\
\hline 2 & $\begin{array}{l}\text { Add virtual lockout points in the BAS based on outdoor } \\
\text { air for baseboard heaters, independently by floor }\end{array}$ & $\begin{array}{l}\text { Implemented in Fall } 2011 \mathrm{w} / \text { mechanical upgrade project. } \\
\text { Lockout based on the indoor temp of the space. }\end{array}$ \\
\hline 3 & $\begin{array}{l}\text { Program holidays into the BAS to enable shutting off the } \\
\text { lighting and HVAC systems }\end{array}$ & Implemented in Fall 2011 w/mechanical upgrade project. \\
\hline 4 & $\begin{array}{l}\text { Update outdoor lighting controls every } 2 \text { weeks or install } \\
\text { daylight sensors }\end{array}$ & $\begin{array}{l}\text { The new BAS installed as part of ARRA mechanical system } \\
\text { upgrade utilizes astronomical data to control outdoor lights }\end{array}$ \\
\hline 5 & $\begin{array}{l}\text { Fitness Center: bi-level switching for lights and } \\
\text { occupancy sensors for offices }\end{array}$ & $\begin{array}{l}\text { Implemented as part of the lighting control package under } \\
\text { ARRA. Occupancy sensors are now installed in large area } \\
\text { throughout building }\end{array}$ \\
\hline 6 & $\begin{array}{l}\text { De-lamp corridor lighting by reducing the number of } \\
\text { lamps per fixture. }\end{array}$ & $\begin{array}{l}\text { New lighting package with controls. This project was just } \\
\text { starting when E4 came out. In general, two double tube T-8s } \\
\text { in corridors are replaced with single-tube T-5s. This brings } \\
\text { the fixture wattage down from } 128 \mathrm{~W} \text { to } 54 \mathrm{~W} \text {. }\end{array}$ \\
\hline 7 & $\begin{array}{l}\text { Add more egress lights to the data centers to remain on } \\
\text { when the light switch is turned off. Post reminders for } \\
\text { staff to turn off the lights when the space is not occupied. }\end{array}$ & $\begin{array}{l}\text { Lighting is swept off after regular office hours. Tenant } \\
\text { agencies must buy-in to make this practical. “Turn Off } \\
\text { Lights” decals are posted. }\end{array}$ \\
\hline 8 & $\begin{array}{l}\text { Disable penthouse exhaust fans below } 40^{\circ} \mathrm{F} \text { and above } \\
65^{\circ} \mathrm{F}\end{array}$ & $\begin{array}{l}\text { Re-commissioning under mechanical upgrade project will } \\
\text { address set points of exhaust fans. Part of new sequence of } \\
\text { operations will be implemented. TBD based on } \\
\text { commissioning agent. }\end{array}$ \\
\hline 9 & $\begin{array}{l}\text { Re-program the control loop for each of the penthouse } \\
\text { exhaust systems to look at the building static sensors ( } 3 \\
\text { per fan) and control the exhaust fan to move enough air } \\
\text { to keep the highest sensor from exceeding } 0.05 \text { inches } \\
\text { positive (or as set). }\end{array}$ & $\begin{array}{l}\text { Implemented as part of the mechanical upgrade project } \\
\text { (ARRA). Sesnors and fans are now controlled by the BAS. }\end{array}$ \\
\hline 10. & $\begin{array}{l}\text { Install VFDs on penthouse fans. When variable } \\
\text { frequency drives (VFDs) are installed on the } \\
\text { supply/exhaust fans, lock the vanes at the optimum blade } \\
\text { pitch to provide required air flow. }\end{array}$ & $\begin{array}{l}\text { Switching to VFDs was a GSA long-term recommendation. } \\
\text { This was implemented with mechanical upgrade project. }\end{array}$ \\
\hline 11. & $\begin{array}{l}\text { Reduce fan static pressure set points by between } 25 \% \text { and } \\
30 \% \text { on nights, weekends, holidays }\end{array}$ & $\begin{array}{l}\text { This was addressed in the mechanical upgrade project. Static } \\
\text { pressure reset is currently being done, but they are not sure } \\
\text { whether it is } 25 \text { to } 30 \% \text { or if it is higher. They noted that fans } \\
\text { are rarely on at night, so the impact may be small }\end{array}$ \\
\hline 12. & $\begin{array}{l}\text { Allow only one stage of supply fan electric heating when } \\
\text { OA temperature is above } 35^{\circ} \mathrm{F} \text {. }\end{array}$ & Implemented via ARRA mechanical upgrade. project \\
\hline 13 & $\begin{array}{l}\text { Supply air temperature reset- raise the supply air } \\
\text { temperature up to between } 55^{\circ} \mathrm{F} \text { and } 65^{\circ} \mathrm{F} \text { based on } \\
\text { outdoor or return air temperatures }\end{array}$ & $\begin{array}{l}\text { Implemented as part of ARRA mechanical project, but the } \\
\text { specific strategy is unknown }\end{array}$ \\
\hline 14 & Re-balance and recalibrate VAV boxes & Completed under ARRA projects \\
\hline 15 & $\begin{array}{l}\text { Repair the failed dampers and failed door latch on } \\
\text { penthouse "A" economizer. Check the other penthouse } \\
\text { economizers to ensure that the dampers and door latches } \\
\text { are in good condition. }\end{array}$ & Both ARRA and normal maintenance addressed this. \\
\hline 16 & $\begin{array}{l}\text { Chilled Water Temperature Reset - based on outdoor-air } \\
\text { temperatures. Use } 48^{\circ} \mathrm{F} \text { for } \mathrm{OA}<60^{\circ} \mathrm{F} \text { and when supply } \\
\text { fans are turned off, } 42^{\circ} \mathrm{F} \text { for } \mathrm{OA}>90^{\circ} \mathrm{F} \text {. }\end{array}$ & ARRA projects, specific strategy unknown \\
\hline 17 & Verify that flex ductwork is not crimped & On-going maintenance and ARRA mechanical upgrade. \\
\hline 18 & $\begin{array}{l}\text { Evaluate CRAC air delivery and temperature setpoints to } \\
\text { make sure adjacent units are not fighting each other. }\end{array}$ & Operations and maintenance contractor; ARRA CRAC project \\
\hline
\end{tabular}


Table 13: Measures Not Implemented - Robert A Young Federal Building

\begin{tabular}{|c|l|l|}
\hline$\#$ & \multicolumn{1}{|c|}{ Recommended Measure } & \multicolumn{1}{|c|}{ Implementation Details / Notes } \\
\hline 19 & $\begin{array}{l}\text { Start penthouse fan schedules } 30 \text { minutes later and stop } \\
30 \text { minutes earlier }\end{array}$ & $\begin{array}{l}\text { Fan schedules not revised; may be addressed with the ARRA } \\
\text { projects. }\end{array}$ \\
\hline 20 & $\begin{array}{l}\text { Disable heater units in office space above } 2^{\text {nd }} \text { floor } \\
\text { walkway when outdoor temp }>55^{\circ} \mathrm{F} \text { (weekdays), } 40^{\circ} \mathrm{F} \\
\text { (weekends). }\end{array}$ & $\begin{array}{l}\text { This was done when the heaters were installed. The } 40^{\circ} \mathrm{F} \text { on } \\
\text { weekends is not an option. }\end{array}$ \\
\hline 21 & $\begin{array}{l}\text { Add control wiring to tie in baseboard heaters with VAV } \\
\text { box controls to mitigate simultaneous heating/cooling. } \\
\text { Allow/configure only one thermostat for controlling both } \\
\text { the VAV boxes and the baseboard heaters }\end{array}$ & $\begin{array}{l}\text { Thermostats still located where they were. All of the } \\
\text { perimeter offices need to be controlled separately because } \\
\text { there is still simultaneous heating and cooling taking place. } \\
\text { There are rows of heaters controlled from a thermostat in one } \\
\text { person's office. Facility staff would like to add controls to } \\
\text { split those units apart. This is very expensive and not } \\
\text { considered a high priority at present. }\end{array}$ \\
\hline 22 & $\begin{array}{l}\text { Shut out the chillers for OA temperatures }<55^{\circ} \mathrm{F} \\
\text { Critical loads require chiller operation to temperatures below } \\
55^{\circ} \mathrm{F} \text {; however, the new chiller with four stages allows } \\
\text { ramping up the chilled water consumption to only the levels } \\
\text { that are needed Use the economizers as much as possible }\end{array}$ \\
\hline 23 & $\begin{array}{l}\text { Lower domestic water loop temperature to } 120^{\circ} \mathrm{F} \\
\text { Not considered because this is not conforming to GSA P-100 } \\
\text { facility standards for hot water loop temperature (140 }{ }^{\circ} \mathrm{F} \text { ) }\end{array}$ \\
\hline
\end{tabular}


Table 14: Measures Fully or Partly Implemented - Goodfellow Federal Center

\begin{tabular}{|c|c|c|}
\hline \# & Recommended Measure & Implementation Details / Notes \\
\hline 1 & $\begin{array}{l}\text { Upgraded controllers on "wild" static pressure/ discharge } \\
\text { pressure control loops }\end{array}$ & Static pressure control was replaced. \\
\hline 2 & $\begin{array}{l}\text { Check and fix daylight sensors for exterior lights such } \\
\text { that the lights are not on during the day }\end{array}$ & All sensors replaced in Building 105 \\
\hline 3 & $\begin{array}{l}\text { De-lamp } 2^{\text {nd }} \text { floor corridor to reduce light levels from } 50 \\
\text { fc to } 10 \mathrm{fc}\end{array}$ & $\begin{array}{l}\text { Staff attempted the original de-lamping to } 10 \mathrm{fc} \text {, but the lower } \\
\text { light settings were unacceptable to tenants. Staff instead } \\
\text { replaced bulbs with CFLs to maintain higher light levels, but } \\
\text { with lower energy consumption. }\end{array}$ \\
\hline 4 & Set minimum occupied OA fraction to $10 \%$ & $\begin{array}{l}\text { For the most part, this was already standard practice; however } \\
\text { for those units that were set to over } 10 \% \text {, they have been } \\
\text { lowered to } 10 \%\end{array}$ \\
\hline 5 & Fix leaking steam valve in Building 105, AHU \#2C3. & Repaired in May 2010 \\
\hline 6 & $\begin{array}{l}\text { Repair ceiling-mounted fan-coil units leaking steam in } \\
\text { penthouse mechanical rooms. }\end{array}$ & $\begin{array}{l}\text { The unit in question has been taken out completely, and its } \\
\text { steam pipe capped off. }\end{array}$ \\
\hline 7 & $\begin{array}{l}\text { Inspect and repair VAV terminal units in Building } 105 \\
\text { that are causing high temperature readings. Possible } \\
\text { leaking hot water or faulty temp sensors. }\end{array}$ & $\begin{array}{l}\text { This was found to be caused by a leaking hot water valve. } \\
\text { The valve was replaced in April } 2010 \text {. }\end{array}$ \\
\hline 8 & $\begin{array}{l}\text { Fix economizer control loops that are exceeding MA set } \\
\text { points and bringing in too much OA }\end{array}$ & $\begin{array}{l}\text { A couple bad controllers were found. They also replaced } \\
\text { some of the welding on OA dampers so that they would seal } \\
\text { better. }\end{array}$ \\
\hline 9 & $\begin{array}{l}\text { Lock out boilers for Building } 105 \text { when OA temperatures } \\
\text { exceed } 60^{\circ} \mathrm{F} \text {. }\end{array}$ & $\begin{array}{l}\text { Controls have generally always been set to } 55^{\circ} \mathrm{F} \text {. At } 55^{\circ} \mathrm{F} \text {, } \\
\text { boilers are locked out. At } 65^{\circ} \mathrm{F} \text {, it switches to summer mode. }\end{array}$ \\
\hline 10 & $\begin{array}{l}\text { Building 105: Interlock one makeup air supply fan to run } \\
\text { with one boiler }\end{array}$ & $\begin{array}{l}\text { Makeup air is generally for the labs on the south end of the } \\
\text { building. They have reduced the number of hoods they are } \\
\text { currently using, which enables reduction in the amount of } \\
\text { makeup air that needs to be brought into the building. }\end{array}$ \\
\hline 11 & $\begin{array}{l}\text { Replace/add weather stripping to entrance and } \\
\text { mechanical room doors }\end{array}$ & $\begin{array}{l}\text { Staff is putting new weather stripping on. Ongoing activity - } \\
10 \% \text { done }\end{array}$ \\
\hline 12 & $\begin{array}{l}\text { Investigate and fix heating control loops that appear to } \\
\text { not be working properly }\end{array}$ & $\begin{array}{l}\text { Staff have been looking at control loops and making } \\
\text { adjustments for communications problems on the bus. } \\
\text { Ongoing issues, but keeping up with trying to get them all } \\
\text { corrected }\end{array}$ \\
\hline 13 & $\begin{array}{l}\text { Tighten lighting schedules where impacts are minimal/ } \\
\text { Eliminate weekend lighting schedules }\end{array}$ & $\begin{array}{l}\text { Some schedules have been tightened, but there is a logistical } \\
\text { problem that is currently being worked out by Building } 105 \\
\text { O\&M contractors. Lighting in } 105 \text { is a new system and lights } \\
\text { go off when scheduled }\end{array}$ \\
\hline 14 & $\begin{array}{l}\text { Review schedules, including holiday schedules to avoid } \\
\text { HVAC runtime when building is unoccupied }\end{array}$ & $\begin{array}{l}\text { Staff are monitoring the HVAC schedules on holidays, } \\
\text { weekends and after hours, and have made significant progress } \\
\text { trying to get these issues resolved. Tenants are also beginning } \\
\text { to realize that if they want to work late, they have to pay for } \\
\text { overtime utilities. }\end{array}$ \\
\hline 15 & $\begin{array}{l}\text { Replace steam boiler with hot water heating (preferably } \\
\text { condensing) boilers }\end{array}$ & $\begin{array}{l}\text { In the process of replacing boilers with more efficient boilers, } \\
\text { but not with condensing boilers because of capital cost of } \\
\text { changing out the rest of building infrastructure. }\end{array}$ \\
\hline 16 & $\begin{array}{l}\text { Review, repair, and replace failed steam traps and } \\
\text { insulate/repair condensate lines }\end{array}$ & $\begin{array}{l}\text { No insulation or repairs performed, but they have repaired and } \\
\text { replaced some of the traps during normal maintenance: } 15 \% \\
\text { were repaired or replaced. The rest appeared normal using } \\
\text { ultrasonic/thermal camera. }\end{array}$ \\
\hline
\end{tabular}


Table 15: Measures Not Implemented - Goodfellow Federal Center

\begin{tabular}{|c|c|c|}
\hline \# & Recommended Measure & Implementation Details / Notes \\
\hline 17 & Schedule 0\% OA from 6:00 a.m.to 6:00 p.m. & $\begin{array}{l}\text { The reason cited for not implementing this measure was that } \\
\text { there were after-hours staff and cleaning crews that required } \\
\text { continued ventilation. E4 staff noted that the } 6 \text { p.m. start time } \\
\text { for this measure could be easily changed to a desirable time to } \\
\text { facilitate implementation. }\end{array}$ \\
\hline 18 & $\begin{array}{l}\text { Install return air sensors that allow for automatic } \\
\text { calculation of outdoor air fraction (OAF) }\end{array}$ & Not yet done. \\
\hline 19 & $\begin{array}{l}\text { Add insulation to steam piping for Building 105, } \\
\text { AHU\#2C3 }\end{array}$ & Not yet done. \\
\hline 20 & $\begin{array}{l}\text { Chilled water temperature reset - raise chilled water } \\
\text { temperature to } 50^{\circ} \mathrm{F} \text { when } \mathrm{OA}<60^{\circ} \mathrm{F} \text {. Lower towards } \\
44^{\circ} \mathrm{F} \text { for hot conditions }\left(\mathrm{OA}>90^{\circ} \mathrm{F}\right)\end{array}$ & $\begin{array}{l}\text { There was a problem when staff tried implementing chilled } \\
\text { water reset in the two annex buildings. When the temperature } \\
\text { was raised, the water was too hot for the annex buildings. So } \\
\text { there are no plans for further changes. }\end{array}$ \\
\hline 21 & Implement hot water temperature setback & Not yet done. \\
\hline 22 & $\begin{array}{l}\text { Operate the boilers with the BAS rather than Debco } \\
\text { system, or try to reconfigure Debco system to avoid } \\
\text { excessive cycling of boilers }\end{array}$ & $\begin{array}{l}\text { Not yet done. It's possible that this capability will be } \\
\text { available with the new boilers being installed. }\end{array}$ \\
\hline 23 & $\begin{array}{l}\text { Replace missing insulation on Building } 105 \text { steam piping } \\
\text { and equipment }\end{array}$ & Has not been done. Not high priority. \\
\hline 24 & Install VFDs on chillers & Has not been done. \\
\hline
\end{tabular}


Table 16: Measures Fully or Partly Implemented - Frank Carlson Federal Building and Courthouse

\begin{tabular}{|l|l|l|}
\hline$\#$ & \multicolumn{1}{|c|}{ Recommended Measure } & \multicolumn{1}{|c|}{ Implementation Details / Notes } \\
\hline 1 & $\begin{array}{l}\text { Reduce minimum OA damper position set point by 50\% } \\
\text { or more }\end{array}$ & $\begin{array}{l}\text { Air handlers for each of the quadrants in the Carlson Federal } \\
\text { Building and Courthouse were recently replaced,. The new } \\
\text { air handlers have been programmed to have 15\% minimum } \\
\text { outdoor air, whereas the previous air handlers were observed } \\
\text { to be bringing in between 35 and } 40 \% \text { minimum outdoor air. }\end{array}$ \\
\hline 2 & $\begin{array}{l}\text { Check/fix possible faulty static pressure sensor on AHU- } \\
\text { NW. Other possibilities include improper configuration } \\
\text { of VFD supply fan }\end{array}$ & Inadvertently fixed during air-handler replacement project \\
\hline 3 & $\begin{array}{l}\text { Moduline terminal units: replace with full VAV system } \\
4\end{array}$ & $\begin{array}{l}\text { Lockout chiller when economizing can handle cooling } \\
\text { replaced with VAV boxes. }\end{array}$ \\
\hline
\end{tabular}


Table 17: Measures Not Implemented - Frank Carlson Federal Building and Courthouse

\begin{tabular}{|c|c|c|}
\hline \# & Recommended Measure & Implementation Details / Notes \\
\hline 5 & $\begin{array}{l}\text { Turn off interior lights at } 6 \text { p.m. weeknights with } \\
\text { overrides for occupants to turn lights back on (All lights } \\
\text { were observed to be on until 9:30 p.m.) }\end{array}$ & $\begin{array}{l}\text { This measure was not implemented at the time of the survey, } \\
\text { but was implemented immediately afterwards, as a result of } \\
\text { the survey }\end{array}$ \\
\hline 6 & De-lamp or add lighting controls to the atrium & $\begin{array}{l}\text { No changes have been made, although E4 team noted in its } \\
\text { December } 2011 \text { visit that the atrium appeared to be mostly lit } \\
\text { with natural light and did not appear to have too many lamps } \\
\text { on. }\end{array}$ \\
\hline 7 & Add timer or daylight sensor controls to perimeters & Not implemented \\
\hline 8 & $\begin{array}{l}\text { Shut down one or two fans earlier in the day (perhaps on } \\
\text { the east side of the building) }\end{array}$ & $\begin{array}{l}\text { There has actually been a modest extension of fan run times } \\
\text { instead of a decrease. }\end{array}$ \\
\hline 9 & $\begin{array}{l}\text { During warm-up/cool down, adjust static pressure set } \\
\text { point to } 75 \% \text { of normal value }\end{array}$ & $\begin{array}{l}\text { Carlson Federal Building and Courthouse staff did not have } \\
\text { the expertise to implement this measure and did not hire JCI } \\
\text { to implement. The site was still using fixed static pressure set } \\
\text { points at the time of the survey. During the targeted-E4 visit } \\
\text { in December 2011, the E4 team implemented full static } \\
\text { pressure reset (24/7), based on VAV box damper commands. }\end{array}$ \\
\hline 10 & $\begin{array}{l}\text { Recalibrate static pressure sensors. They differ from } \\
\text { measurements }\end{array}$ & This measure was not performed \\
\hline 11 & $\begin{array}{l}\text { Start schedules } 30 \text { minutes later and stop } 30 \text { minutes } \\
\text { earlier }\end{array}$ & $\begin{array}{l}\text { There has actually been a modest extension of fan runtimes } \\
\text { instead of a decrease. There currently appears to be the } \\
\text { potential to improve HVAC runtime schedules, especially } \\
\text { using optimal start algorithms. }\end{array}$ \\
\hline 12 & $\begin{array}{l}\text { Use occupancy sensors, controls or smart scheduling to } \\
\text { only provide air flow to court rooms when they are } \\
\text { occupied. }\end{array}$ & $\begin{array}{l}\text { This has not been implemented. This may require a more } \\
\text { advanced scheduling system for courtrooms. }\end{array}$ \\
\hline 13 & Use $\mathrm{CO}_{2}$ sensors for demand control ventilation & $\begin{array}{l}\text { Not implemented. Carlson Federal Building and Courthouse } \\
\text { does not have } \mathrm{CO}_{2} \text { sensors installed inside the building, so } \\
\text { this measure would constitute a significant cost. }\end{array}$ \\
\hline 14 & Schedule $0 \%$ OA from 5 p.m. to 7 a.m. & $\begin{array}{l}\text { Not implemented. This is currently a recommendation in the } \\
\text { targeted-E4 report (January 2012) for the site, and is on a list } \\
\text { of measures to be implemented by the E4 team later in } 2012 \text {. }\end{array}$ \\
\hline 15 & $\begin{array}{l}\text { Supply air temperature reset - use higher temperatures } \\
\text { based on either outdoor air temp, return air temp, space } \\
\text { temp }\end{array}$ & $\begin{array}{l}\text { Carlson Federal Building and Courthouse was still using } \\
\text { seasonal supply air temperature set points that varied by air } \\
\text { handler at the time of the survey. During the targeted-E4 visit } \\
\text { in December 2011, the E4 team implemented supply air } \\
\text { temperature reset (24/7), based on return air temperature. }\end{array}$ \\
\hline 16 & $\begin{array}{l}\text { Nighttime setback on perimeter heating units - reduce } \\
\text { occupied set point by } 10^{\circ} \mathrm{F} . \text { OR... delay HVAC system } \\
\text { startup in heating season. }\end{array}$ & $\begin{array}{l}\text { Not implemented at the time of the survey. A constant } \\
\text { heating set point of } 73^{\circ} \mathrm{F} \text { was being used year-round. During } \\
\text { the targeted-E } 4 \text { visit in December } 2011 \text {, the E } 4 \text { team } \\
\text { implemented this measure, with the setback temperature set at } \\
65^{\circ} \mathrm{F} \text {. }\end{array}$ \\
\hline 17 & $\begin{array}{l}\text { Chilled water differential pressure reset - reduce } \\
\text { differential pressure set point during times of lighter load }\end{array}$ & $\begin{array}{l}\text { Not implemented at the time of the survey. During the } \\
\text { targeted-E4 visit in December 2011, the E4 team implemented } \\
\text { this measure. }\end{array}$ \\
\hline 18 & $\begin{array}{l}\text { Chilled water temperature reset - raise chilled water set } \\
\text { point by } 1 \text { to } 2^{\circ} \mathrm{F} \text { or implement OA temperature-based } \\
\text { chilled water temperature with JCI help. Recommended } \\
\text { re-piping of chillers before more substantial measures } \\
\text { taken. }\end{array}$ & $\begin{array}{l}\text { Not implemented at the time of the survey. During the } \\
\text { targeted-E4 visit in December 2011, the E4 team implemented } \\
\text { this measure. }\end{array}$ \\
\hline 19 & Fix primary-secondary chilled-water piping bridge & Not implemented. Estimated to be not cost-effective. \\
\hline
\end{tabular}


Table 18: Measures Fully or Partly Implemented - Charles Evans Whittaker U.S. Courthouse

\begin{tabular}{|c|c|c|}
\hline \# & Recommended Measure & Implementation Details / Notes \\
\hline 1 & Replace worn weather stripping on exterior doors. & $\begin{array}{l}\text { O\&M staff are currently fixing doors with worn weather- } \\
\text { stripping. This is a continuous improvement that is performed } \\
\text { as needed. Most doors have weather stripping in a good state } \\
\text { of repair right now. }\end{array}$ \\
\hline 2 & $\begin{array}{l}\text { Use after-hours timers for interior lights or control with } \\
\text { energy management control system (EMCS) system } \\
\text { using building-wide sweeps every } 2 \text { hours }\end{array}$ & Most lighting is now swept off using the BAS. \\
\hline 3 & $\begin{array}{l}\text { Use daylighting or timer controls for the atrium and } \\
\text { lobby lights. }\end{array}$ & $\begin{array}{l}\text { Atrium lights have been switched over to LEDs and are } \\
\text { timer/EMS controlled. Just for the atrium at this point, but as } \\
\text { more efficient lighting options available, they are looking to } \\
\text { retrofit more areas. They de-lamped a large portion of } \\
\text { common space lighting in the building. Also, certain agencies } \\
\text { are willing to de-lamp some of their tenant space. Staff is } \\
\text { considering retrofit for exterior lights to LEDs. }\end{array}$ \\
\hline 4 & Remove inlet vanes on penthouse supply fans with VFD. & Inlet vanes have either been removed or locked open \\
\hline 5 & $\begin{array}{l}\text { Reduce HVAC schedules by } 20 \text { minutes (start up } 10 \\
\text { minutes later in morning, shut down } 10 \text { minutes earlier in } \\
\text { evening). }\end{array}$ & $\begin{array}{l}\text { Whittaker Courthouse has optimized their schedules for } \\
\text { energy conservation and has now reduced fan operation by } 45 \\
\text { minutes. They are generally starting up } 30 \text { minutes later in } \\
\text { the morning and shutting off } 15 \text { minutes earlier in the evening }\end{array}$ \\
\hline 6 & $\begin{array}{l}\text { Modify the minimum outdoor air damper position to be } \\
0 \% \text { instead of } 10 \%\end{array}$ & Implemented \\
\hline 7 & $\begin{array}{l}\text { Lock and tag off the cooling tower heater disconnects } \\
\text { during the summer. }\end{array}$ & Implemented \\
\hline 8 & $\begin{array}{l}\text { Remove/disconnect dehumidifiers deemed to be } \\
\text { unnecessary. }\end{array}$ & $\begin{array}{l}\text { Currently taking place in certain areas and further } \\
\text { consideration will be given to additional areas }\end{array}$ \\
\hline
\end{tabular}


Table 19: Measures Not Implemented - Charles Evans Whittaker U.S. Courthouse

\begin{tabular}{|c|c|c|}
\hline \# & Recommended Measure & Implementation Details / Notes \\
\hline 9 & $\begin{array}{l}\text { Install watt misers, timer controls, or occupancy sensors } \\
\text { to lighting in corridors }\end{array}$ & Not implemented (lack of funding). \\
\hline 10 & $\begin{array}{l}\text { Install watt misers, timer controls, or occupancy sensors } \\
\text { on vending machines }\end{array}$ & Not implemented \\
\hline 11 & $\begin{array}{l}\text { Reduce fan static pressure by 1/3 around 3:00 p.m. - 4:00 } \\
\text { p.m.; return to normal around 1:00 a.m. }\end{array}$ & $\begin{array}{l}\text { Building staff seem to be uncomfortable with or do not } \\
\text { understand the benefit of switching to a lower static pressure } \\
\text { set point toward the end of the day. O\&M staff mentioned that } \\
\text { they do their best to lower set points in general when possible, } \\
\text { but seek to maintain occupant comfort. }\end{array}$ \\
\hline 12 & $\begin{array}{l}\text { Reprogram demand control }\left(\mathrm{CO}_{2}\right) \text { ventilation so that } \\
\text { maximum demand-controlled outdoor air fraction is } 30 \% \\
\text { instead of } 100 \% \text {. }\end{array}$ & $\begin{array}{l}\text { O\&M staff indicated that this has not changed. Staff } \\
\text { mentioned that there is probably no benefit of pulling in 100\% } \\
\text { outdoor air for a shorter period of time versus pulling in 30\% } \\
\text { outdoor air for a longer period of time. Their minimum } \\
\text { outside air set point is now set to 0, which indicates that it } \\
\text { may be adequate. }\end{array}$ \\
\hline 13 & $\begin{array}{l}\text { Reprogram controls for supply air to bypass the heating } \\
\text { coils when outside air temperatures are above } 50^{\circ} \mathrm{F} \text {. }\end{array}$ & $\begin{array}{l}\text { Measure was attempted, however because of the various space } \\
\text { requirements, a small amount of heat is needed to maintain } \\
\text { tenant satisfaction }\end{array}$ \\
\hline 14 & $\begin{array}{l}\text { Implement VAV discharge air temperature reset - reset } \\
\text { the set point of the discharge air between } 55^{\circ} \mathrm{F} \text { and } 65^{\circ} \mathrm{F} \text {, } \\
\text { based on return air temperature or average of } 3 \text { or more } \\
\text { zone space sensors and deviation from set point. }\end{array}$ & $\begin{array}{l}\text { Not implemented. Staff would need a controls contractor to } \\
\text { implement this change }\end{array}$ \\
\hline 15 & $\begin{array}{l}\text { Move humidity sensors away from cooling towers into a } \\
\text { more representative location for outdoor air. Repair/ } \\
\text { replace/recalibrate critical outdoor and return air } \\
\text { humidity sensors. }\end{array}$ & $\begin{array}{l}\text { Funding not available to move humidity sensor. They may } \\
\text { still consider recalibrating the sensor. }\end{array}$ \\
\hline 16 & $\begin{array}{l}\text { Shut down heating system (pumps, valves) when OA } \\
\text { temperature is }>60^{\circ} \mathrm{F} \text { and building is unoccupied (5:00 } \\
\text { p.m.-5:00 a.m., Monday through Friday; weekends and } \\
\text { holidays) }\end{array}$ & $\begin{array}{l}\text { O\&M staff seemed to be concerned about the building getting } \\
\text { too cold, which probably indicates they haven't thought } \\
\text { through the recommendation very well, because the } \\
\text { suggestion is to implement this only when outdoor air } \\
\text { temperatures are }>60^{\circ} \mathrm{F} \text {. }\end{array}$ \\
\hline 17 & $\begin{array}{l}\text { Shut off (valve off) steam to the air handlers, heating } \\
\text { coils, and dehumidifiers from June } 1 \text { to October } 1 .\end{array}$ & $\begin{array}{l}\text { According to maintenance staff, the building requires a small } \\
\text { amount of steam for both heating and humidification during } \\
\text { the summer, and this is not a significant issue }\end{array}$ \\
\hline 18 & Replace steam heating system with gas boilers. & No funding available for capital projects \\
\hline 19 & Install VFDs on cooling tower fans & No funding available for capital projects \\
\hline
\end{tabular}


Table 20: Measures Fully or Partly Implemented - Edward Zorinsky Federal Building

\begin{tabular}{|c|c|c|}
\hline$\#$ & Recommended Measure & Implementation Details / Notes \\
\hline 1 & $\begin{array}{l}\text { Trend night time zone temperatures along with cooling } \\
\text { coil and economizer operation. Verify that the cooling } \\
\text { coil/economizer is being driven by zones that are } 80^{\circ} \mathrm{F}\end{array}$ & Implemented in 2010 \\
\hline 2 & $\begin{array}{l}\text { Lock out the preheat coils on all AHUs above } 35^{\circ} \mathrm{F} \text {. } \\
\text { Adopt a wider dead band during winter. Recommend } \\
\text { heating set points } 68^{\circ} \mathrm{F} \text { to } 70^{\circ} \mathrm{F} \text {., cooling set point } 78^{\circ} \mathrm{F}\end{array}$ & $\begin{array}{l}\text { Valve position set at } 35^{\circ} \mathrm{F} \text { in October } 2011 \text {; thermostat set } \\
\text { points have not been changed yet because of logistical } \\
\text { constraints }\end{array}$ \\
\hline 3 & $\begin{array}{l}\text { Raise the lock out outdoor air temperature for chilled } \\
\text { water loop from } 52^{\circ} \mathrm{F} \text { to } 54^{\circ} \mathrm{F}\end{array}$ & Implemented in December 2010 \\
\hline 5 & $\begin{array}{l}\text { Raise the cooling set point for the telecommunications } \\
\text { room to between } 75^{\circ} \mathrm{F} \text { and } 78^{\circ} \mathrm{F}\end{array}$ & Implemented in December 2011 \\
\hline 6 & $\begin{array}{l}\text { Raise the upper limit of dry-bulb temperature for } \\
\text { economizing to } 65^{\circ} \mathrm{F} \text { between Oct. } 1 \text { and Apr. } 20 \text {; } \\
\text { implement enthalpy based economizer controls }\end{array}$ & $\begin{array}{l}\text { Implemented new temperature limits in December 2010; } \\
\text { enthalpy control requires BAS expertise not available in- } \\
\text { house }\end{array}$ \\
\hline 7 & $\begin{array}{l}\text { Re-examine higher minimum OAF requirements in } \\
\text { AHU-1, } 10 \text { and } 11 \text {. Bring these down by } 10 \% \text { if possible }\end{array}$ & Implemented in January 2011 \\
\hline 10 & $\begin{array}{l}\text { Reduce HVAC schedules by } 1 \text { hour (Suggested } 30 \\
\text { minutes late start and } 30 \text { minutes early shut down) }\end{array}$ & Implemented in January 2011, startup delayed by 1 hour \\
\hline 13 & $\begin{array}{l}\text { Have building staff perform an after-hour review to } \\
\text { determine specific areas where the lights could be shut- } \\
\text { off after hours; commission a lighting study to develop } \\
\text { an implementation plan to shut down lights after hours }\end{array}$ & $\begin{array}{l}\text { During a power outage in October 2011, all emergency lights } \\
\text { were identified; currently a separate study is in progress for } \\
\text { lighting system upgrade }\end{array}$ \\
\hline 15 & $\begin{array}{l}\text { Replace all dielectric couplings on VAV heating coil } \\
\text { valves with more durable fittings, then perform hot water } \\
\text { reset, and hot water lockout during the summer }\end{array}$ & Current on-going project to replace the dielectric couplings \\
\hline
\end{tabular}

Table 21: Measures Not Implemented - Edward Zorinsky Federal Building

\begin{tabular}{|c|c|c|}
\hline \# & Recommended Measure & Implementation Details / Notes \\
\hline 4 & $\begin{array}{l}\text { Maintain day time cooling set points for the } 7^{\text {th }} \text { floor at } \\
\text { night during the cooling season to avoid humidity issues } \\
\text { with the } 7^{\text {th }} \text { floor data center; ensure that there are no } \\
\text { unsealed penetrations in the } 7^{\text {th }} \text { floor data center walls, } \\
\text { floor and ceiling }\end{array}$ & $\begin{array}{l}\text { Staff do not believe this is an issue and are also unaware of } \\
\text { the penetrations; so further review is planned }\end{array}$ \\
\hline 8 & $\begin{array}{l}\text { Investigate inconsistent temperatures observed in AHU-7 } \\
\text { and resolve }\end{array}$ & $\begin{array}{l}\text { Staff do not believe the temperatures observed by E4 team are } \\
\text { accurate }\end{array}$ \\
\hline 9 & $\begin{array}{l}\text { Configure AHU-16 to run on manual control to be turned } \\
\text { on only when the sub-basement is occupied }\end{array}$ & $\begin{array}{l}\text { AHU runs only during day; has no heating/cooling coil; no } \\
\text { action will be taken due to manual overrides needed }\end{array}$ \\
\hline 11 & $\begin{array}{l}\text { Stage hot water pumps P-3 and P-4 in lead-lag mode } \\
\text { rather than in parallel }\end{array}$ & $\begin{array}{l}\text { Will require a stage switch and additional programming that is } \\
\text { not within the O\&M budget; need additional funding }\end{array}$ \\
\hline 12 & $\begin{array}{l}\text { Schedule cafeteria and dining room area lights to shut off } \\
\text { at 2:00 p.m., and come on at 6:00 a.m. during weekdays } \\
\text { and remain turned off during weekends and holidays; } \\
\text { also consider using motion sensors after dining hours }\end{array}$ & $\begin{array}{l}\text { Currently these are on a timer and no plans to update this } \\
\text { because of public access to the area and difficulty with the } \\
\text { current electrical wiring to install additional sensors }\end{array}$ \\
\hline 14 & $\begin{array}{l}\text { Have insulation blown over the ceiling tiles above } 9^{\text {th }} \\
\text { floor; also consider hiring a mechanical contractor to re- } \\
\text { duct the return air for the } 9^{\text {th }} \text { floor so that it is not pulling } \\
\text { air from unconditioned } 10^{\text {th }} \text { floor catwalk area }\end{array}$ & $\begin{array}{l}\text { It's a large project requiring design and cost estimate, in } \\
\text { conjunction with adding a ducted return. }\end{array}$ \\
\hline 16 & Implement static pressure reset & Require a BAS system programmer, no in-house expertise \\
\hline 17 & Implement water loop differential pressure reset & $\begin{array}{l}\text { Will be considered after the dielectric unions are replaced as } \\
\text { described in item } 15 \text {. }\end{array}$ \\
\hline 18 & Add all building lighting controls to the BAS & $\begin{array}{l}\text { Very expensive, large project; will require removal of exiting } \\
\text { motion sensors and a new interface to BAS. Will be } \\
\text { considered in the 5-year project planning. }\end{array}$ \\
\hline
\end{tabular}




\title{
APPENDIX B
}

\author{
Weather Correction
}




\section{Appendix B: Weather Correction}

For each city with one or more buildings visited as part of the E4 program, the actual weather for each month in the analysis period has been collected, according to the number of heating degree-days (HDD) and cooling degree-days (CDD). HDDs and CDDs are used in this type of analysis because they are typically proportional to the heating and cooling loads experienced by a building. HDDs are calculated for a given day by calculating the average daily temperature, in ${ }^{\circ} \mathrm{F}$, and subtracting that from the base temperature, if the average is above that base temperature. So if the average daily temperature is $45^{\circ} \mathrm{F}$ and the base is $65^{\circ} \mathrm{F}$, there were 20 HDDs that day. Likewise, CDDs are calculated by subtracting the base temperature from the average daily temperature when the average daily temperature is higher than the base temperature. The HDDs and CDDs are summed for each day in a given month to give a proxy for heating and cooling loads in each month. The source of the actual weather data is www.wunderground.com. This website provides a monthly summary for each weather location that includes HDD (base 65), CDD (base 65) and CDD (base 50). Commercial buildings typically have a base (average daily temperature for which no heating and cooling is needed for perimeter zones) of around $55^{\circ} \mathrm{F}$. In the absence of HDDs and CDDs calculated with this ideal base, the HDD (base 65) and CDD (base 50) are used as the best available proxies.

Figure 26 and Figure 27 below show HDDs and CDDs plotted for each year for FY07-FY11 for Des Moines, IA. In addition to this data is the 'normal' number of CDDs and HDDs on the leftmost data series of each plot. Normal degree days for each month are determined from the typical meteorological year (TMY2) weather files. In the absence of reliable 30-year averages, this is the best approximation of the typical values for each month.

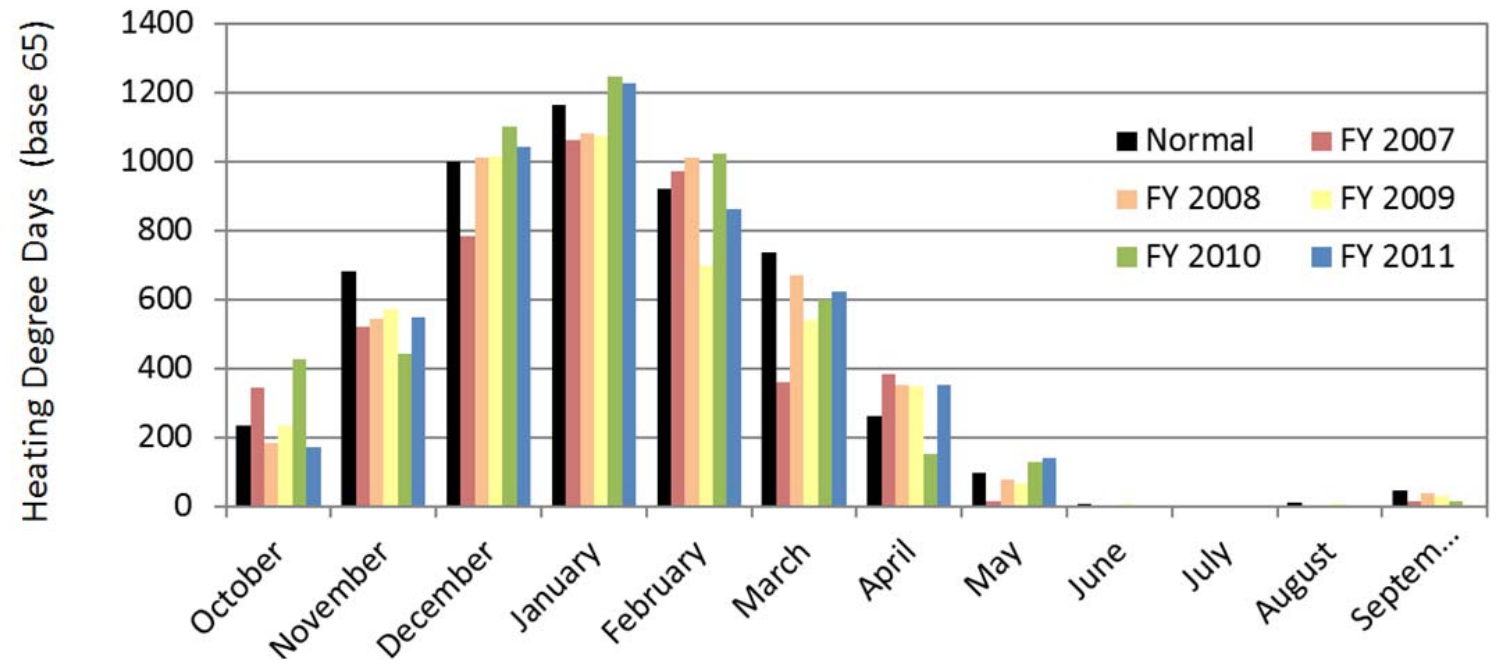

Figure 26: Heating Degree Days for Des Moines, IA 


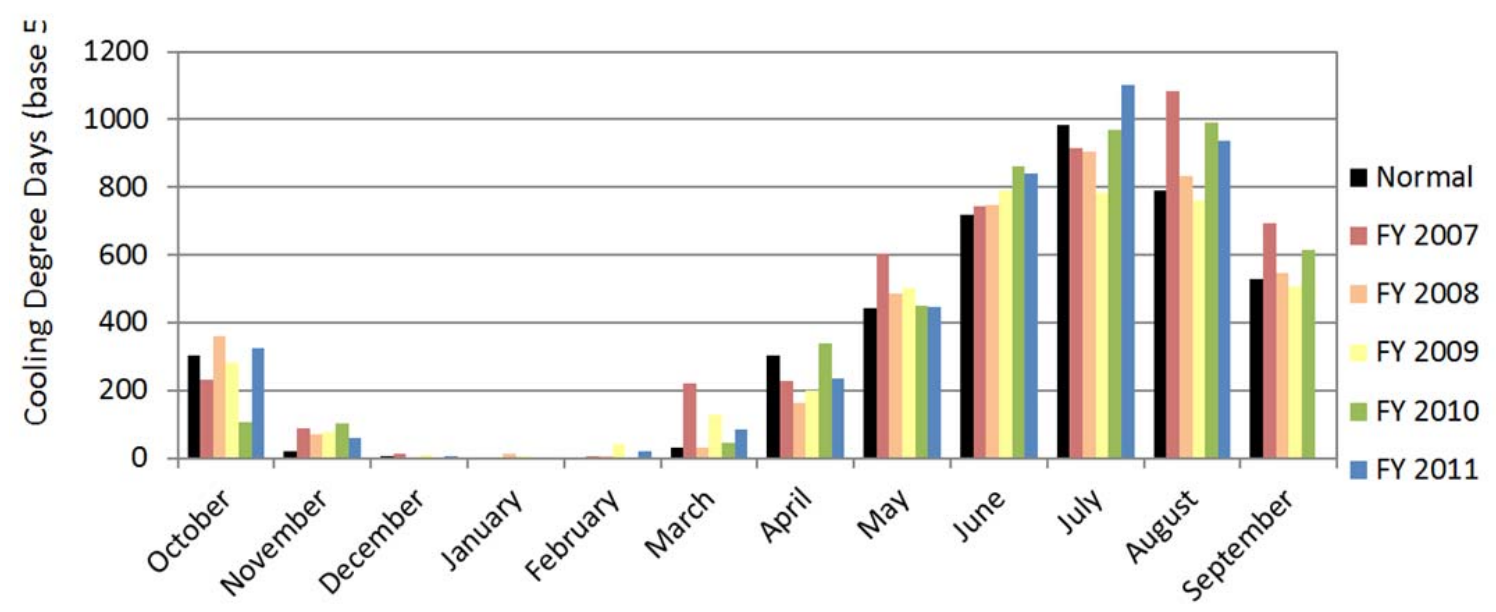

Figure 27: Cooling Degree Days for Des Moines, IA

Based on this climatological data for each month in each location, as well as utility data for each month, correlations can be developed to determine the relationship between the number of HDDs and CDDs and energy consumption. These correlations are developed using the following guidelines:

- Only the months before the E4 visit are used in development of the correlations to avoid confusing reduced consumption from improvements with reduced consumption caused by weather.

- HDD correlations are developed only for months where there is a significant heating load (>100 HDDs), and CDD correlations are likewise developed only for months where there is a significant cooling load (>100 CDDs).

- The $\mathrm{R}^{2}$ value for the data series is used as a measure of the strength of the correlation. $\mathrm{R}^{2}$ values below 0.5 are considered weak or non-existent correlations, and in these cases, the climatological variable in questions (HDD or CDD) is not considered predictive of energy consumption for that type of fuel at that facility.

- For those correlations with $\mathrm{R}^{2}$ values greater than 0.5 , the slope of the least-square fit trend line represents the additional energy consumption required for each additional HDD or CDD for that fuel type at that facility.

- For each fuel type, the actual consumption in each month can be corrected to the equivalent consumption in a normal weather month by finding the departure from normal CDDs/HDDs, multiplying that number by the slope of the trend line, and subtracting that value from the actual consumption in that month. Months with below normal HDDs or CDDs will be corrected higher, while months with above normal CDDs or HDDs will be corrected lower, if there exists a corresponding correlation.

Figure 28 shows as an example the correlation between electricity consumption and HDDs/CDDs for the Bannister Complex in Des Moines, IA. For electricity, there is a strong correlation with CDDs $\left(\mathrm{R}^{2}=\right.$ $0.81)$, but no correlation with HDDs $\left(\mathrm{R}^{2}=0.0096\right)$. The slope of the CDD vs. electricity consumption trend line is $0.824 \mathrm{Btu} / \mathrm{sf}$.-month, so each additional CDD in Kansas City results in 0.824 Btu additional electricity consumption per square foot at Bannister. 


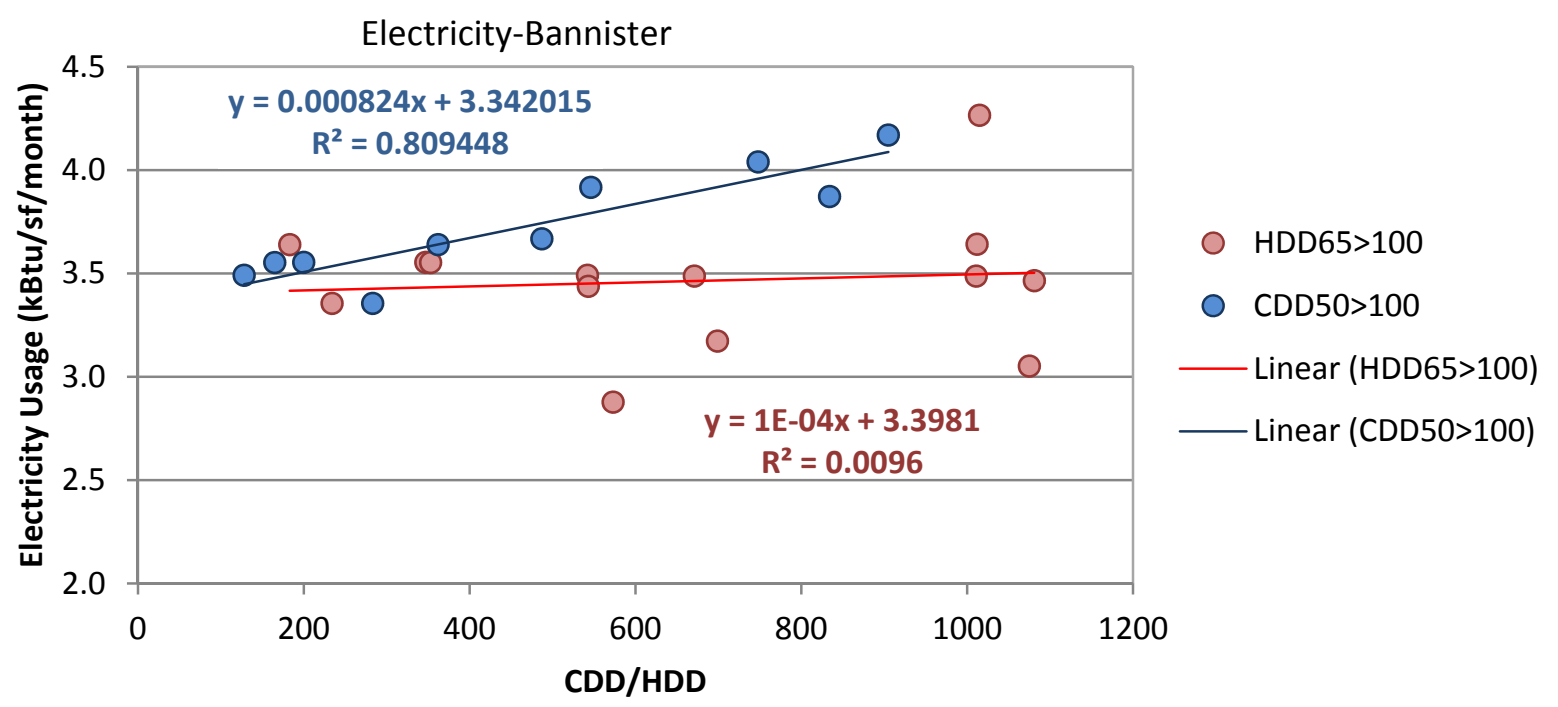

Figure 28: Correlations between Electricity Consumption and Weather for Bannister Complex before E4 Visit 